\title{
A review on Fenton-like processes for organic wastewater treatment
}

\author{
Nannan Wang, ${ }^{\mathrm{a}, \mathrm{b}}$, Tong Zheng ${ }^{\mathrm{b}}$, Guangshan Zhang ${ }^{\mathrm{b}}$ and Peng Wang, ${ }^{\mathrm{a}, \mathrm{b},{ }^{*}}$ \\ ${ }^{\text {a }}$ State Key Laboratory of Urban Water Resource and Environment, Harbin Institute \\ of Technology, Harbin 150090, PR China. \\ ${ }^{\mathrm{b}}$ School of Municipal and Environmental Engineering, Harbin Institute of \\ Technology, Harbin 150090, PR China.
}

\begin{abstract}
Fenton-like processes have been studied widely in recent years and are considered promising for organic wastewater treatment. Due to the demand for high efficiency wastewater treatment, a summary of the study status of Fenton-like processes is necessary to develop a novel and high efficiency organic wastewater treatment method. In this review, some important effect parameters $\left(\mathrm{pH}, \mathrm{H}_{2} \mathrm{O}_{2}\right.$ dosage, catalyst dosage, temperature) in hetero-/homo-geneous Fenton-like processes are discussed, and then the physical field/phenomenon-assisted hetero-/homo-geneous Fenton-like processes are presented. After that, catalyst types and the evaluation of wastewater treatment costs for various Fenton-like processes are summarized and discussed. Finally, possible future research directions and some guidelines for Fenton-like processes are given.
\end{abstract}

Key Words: Fenton-like; photo-Fenton-like; electro-Fenton-like; microwave-Fenton-like; cavitation-Fenton-like; catalyst

\footnotetext{
* Corresponding author: Prof. P. Wang; Tel.: +86 451 86283109; Fax: +86 45186283109.

E-mail address: pwang73@hit.edu.cn;

Postal address: School of Municipal and Environmental Engineering, Harbin Institute of Technology, No. 73 Huanghe Road, Nangang District, Harbin, 150090, China. 


\section{Introduction}

In recent years, advanced oxidation processes (AOPs) have been studied as a promising kind of organic wastewater (WW) treatment method based on the in situ generation of hydroxyl radicals (HO·), which have a strong oxidation capacity (standard potential=2.80 V versus standard hydrogen electrode) $[1,2]$. Under treatment by AOPs complex organic molecules can be either oxidized by $\mathrm{HO}$ to smaller organics or completely mineralized to carbon dioxide $\left(\mathrm{CO}_{2}\right)$ and water $\left(\mathrm{H}_{2} \mathrm{O}\right)$ [3-6]. Many organic WW treatment methods that are based on $\mathrm{OH}$ - generation can be called AOPs, such as $\mathrm{Fe}(\mathrm{II}) / \mathrm{H}_{2} \mathrm{O}_{2}$ [7], $\mathrm{Fe}(\mathrm{II}) / \mathrm{H}_{2} \mathrm{O}_{2} / \mathrm{UV}$, ozonation $\left(\mathrm{O}_{3}\right)$ [8], $\mathrm{O}_{3} / \mathrm{H}_{2} \mathrm{O}_{2}$ [9], $\mathrm{H}_{2} \mathrm{O}_{2} / \mathrm{UV}$ [10], hetero-/homo-geneous Fenton-like processes, $\mathrm{TiO}_{2} / \mathrm{UV}$ [11], $\mathrm{ZnO} / \mathrm{UV}$ [12], and some other processes involving the photo field, electric field, cavitation effect, microwave field, etc. [13].

One of the most frequently used AOPs is the Fenton process where $\mathrm{Fe}^{2+}$ is used as the catalyst and hydrogen peroxide $\left(\mathrm{H}_{2} \mathrm{O}_{2}\right)$ as the oxidant. The mechanism of the Fenton process has often been described $[14,15]$. It has many advantages such as its high performance and simplicity (operated at room temperature and atmospheric pressure) for the oxidation of organics $[16,17]$ and its non-toxicity [18] $\left(\mathrm{H}_{2} \mathrm{O}_{2}\right.$ can break down into environmentally safe species like $\mathrm{H}_{2} \mathrm{O}$ and oxygen $\left(\mathrm{O}_{2}\right)$ ).

Based on the above advantages, the Fenton process has been applied to treat many kinds of WW such as olive-oil mill WW [19], textile WW [20], laboratory WW [21], pesticide WW [22], cosmetic WW [23], dye WW [24, 25], fermentation brine from green olives [26], pharmaceutical WW [27], cork cooking WW [28], pulp mill effluents [29], and phenolic WW [30]. However, although the Fenton process has been studied widely and has performed well in the above WW treatments, it still has some disadvantages such as high operating cost, limited optimum $\mathrm{pH}$ range (always 
works best at around $\mathrm{pH}=3$ ), large volume of iron sludge produced, and difficulties in recycling of the homogeneous catalyst $\left(\mathrm{Fe}^{2+}\right)$ [31]. Additionally, the required concentration range of the iron ion is $50-80 \mathrm{ppm}$ for batch processes, which is clearly above the 2 ppm limit imposed by the European Union (EU) directives for direct discharge of wastewater into the environment [32].

In order to overcome these disadvantages, enhancement of the Fenton process has attracted much attention by researchers. Some other kinds of hetero-/homo-geneous catalyst (except for $\mathrm{Fe}^{2+}$ ) were used to replace $\mathrm{Fe}^{2+}$, including $\mathrm{Fe}^{3+}$ [33], $\mathrm{Cu}^{2+} / \mathrm{Cu}^{+}$ [34], schorl [35], pyrite [36], and nano zero-valent iron [37]. These established systems are called hetero-/homo-geneous Fenton-like processes.

Furthermore, physical field(s)/phenomenon can also be used in both the classic Fenton process and hetero-/homo-geneous Fenton-like processes to enhance the WW treatment efficiency. The typical physical fields/phenomenon include the photo field, electro field, cavitation effect, and microwave field, which correspond to the photo-Fenton/Fenton-like processes [38-40], electro-Fenton-like processes [41-43], cavitation-Fenton-like processes [44-46], and microwave-Fenton-like processes [47, 48], respectively, in both hetero- and homo-generous Fenton-like processes.

The basic difference between the homogeneous and heterogeneous Fenton-like processes involves the different positions where the catalytic reactions occur. In the homogeneous system, the catalysis process can occur in the whole liquid phase, while in the heterogeneous system the catalysis process always occurs on the surface of the catalyst. The position at which catalysis occurs in the heterogeneous system determines that the diffusion and adsorption processes of $\mathrm{H}_{2} \mathrm{O}_{2}$ and other reactants to the surface of catalyst could be significant for the catalysis process $[49,50]$. 
For the study of the Fenton-like processes mentioned above, various organics were chosen as target contaminants such as dyes [35, 51], drugs [52-54], and pesticides [46]. Most of the above organic compounds present in the WW are refractory to biological treatment and toxic to aquatic organisms, even to human beings. The concentration range studied was always from hundreds of $\mu \mathrm{g} / \mathrm{L}$ to hundreds of $\mathrm{mg} / \mathrm{L}[38,55,56]$.

In recent years, some typical reviews $[43,57,58]$ have been published regarding different aspects of the introduction of Fenton/Fenton-like processes. Pliego et al. [58], in their review, presented various methods that can enhance Fenton-like processes, such as radiation, electrochemistry, and heterogeneous catalysts; Bautista et al. [57] provided detailed information on the application of the Fenton process for the treatment of industrial WW. Brillas et al. [43] gave a profound introduction to the electro-Fenton processes and the related electrochemical technologies. In our review, the important effect parameters $\left(\mathrm{pH}, \mathrm{H}_{2} \mathrm{O}_{2}\right.$ dosage, catalyst dosage, temperature, etc.) are discussed in detail, and then the physical fields/phenomenon-assisted Fenton-like processes are presented. After that, a conclusion about the most suitable catalysts is made in the forth section and the costs of different Fenton-like processes are compared in the fifth section. Finally, recommended research directions for the future and some guidelines are given. The aim of this review is to discuss Fenton-like processes from aspects that are significant in the study of Fenton-like processes and were previously seldom considered but are valuable (such as the types of catalyst). We hope that this paper, based on the systematic introduction below, will provide valuable viewpoints and promote the development of Fenton-like processes.

\section{Fenton-like processes}


Fenton-like processes consist of heterogeneous and homogeneous Fenton-like processes. Heterogeneous Fenton-like processes can be established by replacing $\mathrm{Fe}^{2+}$ in the Fenton reagent with a solid catalyst, while homogeneous Fenton-like processes are due to a combination of other metal ion(s)/metal ion-organic ligand complexes and $\mathrm{H}_{2} \mathrm{O}_{2}$ [59]. In Fenton-like systems $\mathrm{pH}, \mathrm{H}_{2} \mathrm{O}_{2}$ dosage, catalyst dosage, and reaction temperature have been studied widely because of their significant effect on the oxidation capacity of the Fenton-like reagent. Thus, the systematic introduction and analysis of these parameters is necessary.

\section{$2.1 \mathrm{pH}$}

In Fenton-like processes $\mathrm{pH}$ is a highly important parameter for effective WW treatment. However, in the previous studies the researchers always reached different conclusions about the $\mathrm{pH}$. In the heterogeneous Fenton-like processes some studies revealed that $\sim 3$ was still the best $\mathrm{pH}$, while others showed that the neutral condition (even alkaline conditions) could achieve a better organic WW treatment efficiency. Yang et al. [51] and $\mathrm{Xu}$ et al. [35], from different research groups, applied magnetic NdFeB-activated carbon (AC) and schorl, respectively, to treat dye WW. Both of them observed that the organics in WW could be treated effectively under acidic condition ( $\mathrm{pH} 3$ (Figure 1a) and 2-4, respectively), and the treatment efficiency decreased obviously with an increase in pH (No. 1 and 8 in Table 1). However, Huang et al. [60] and Feng et al. [61], from different research groups, had different study results. Both of their studies showed that organic WW could be treated effectively under close to neutral ( $\mathrm{pH}$ 6.0) (even slightly alkaline ( $\mathrm{pH} 9.0)$ ) conditions when iron oxide/ $/ \mathrm{SiO}_{2}$ composite (Figure 1b) and pyrite were applied, respectively (No. 5 and 6 in Table 1). 
Figure 1

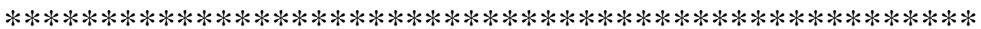

The different solubilities of a metal ion (such as the Fe ion) on the surface of a catalyst and the different activities of active sites on the catalyst surface could be the primary reason. Some kinds of catalyst could play a catalytic role mainly by means of the dissolution of metal ions from the catalyst surface, while other kinds of catalyst may perform mainly through the active sites on their surface. For the former case, the increase in $\mathrm{pH}$ could be able to stop/slow the leaching of metal ions from the solid catalyst surface and inactivate the metal ions in the aqueous phase due to hydrolysis and precipitation. For the latter case, the catalysts could be more resistant to $\mathrm{pH}$ because they play the catalytic role through the active sites.

Nevertheless, although the result is different, all of their research results showed that the $\mathrm{pH}$ used in organic WW treatment could not be increased without any limitation; in other words, there was always an optimum $\mathrm{pH}$ value/range for the WW treatment.

In the homogeneous Fenton-like processes, many researchers [62-66] have reported $\mathrm{pH}$ 2.5-3.0 to be the optimum $\mathrm{pH}$ range for the degradation of most organic compounds. These studies showed that with a decrease in $\mathrm{pH}(<2.5)$, the scavenging effect of the $\mathrm{HO} \cdot$ radicals by $\mathrm{H}^{+}$becomes stronger (reaction equation 1 ).

$\mathrm{HO} \cdot+\mathrm{H}^{+}+e^{-} \rightarrow \mathrm{H}_{2} \mathrm{O}$

On the contrary, for $\mathrm{pH}>3.0$ the hydrolysis and precipitation of $\mathrm{Fe}^{3+}$ in the solution can reduce the catalytic capacity of itself (No. 12-14 and 16-18 in Table 1). However, there are also different results from a small number of studies. You et al. [67] revealed that at $\mathrm{pH} 6$ a better treatment result was obtained when they treated molasses alcohol 
WW using $\mathrm{Fe}^{3+}$ as the homogeneous Fenton-like catalyst (No. 15 in Table 1). This could be due to the coagulation of ferric species [66], which can play an important role under neutral conditions.

According to the statement above, the study of the optimum $\mathrm{pH}$ value/range could be a complicated but significant issue, which can only be determined experimentally. Nevertheless, the previous studies have presented a positive trend for the broadening of the $\mathrm{pH}$ range because at least some studies (especially in the heterogeneous systems) have showed a satisfactory WW treatment efficiency under neutral/alkaline conditions.

\section{$2.2 \mathrm{H}_{2} \mathrm{O}_{2}$ dosage}

In the Fenton-like processes, $\mathrm{H}_{2} \mathrm{O}_{2}$, as the dominant source of $\mathrm{HO}$. under catalysis, plays a critical role in the treatment of organic WW. The optimum $\mathrm{H}_{2} \mathrm{O}_{2}$ dosage must be determined experimentally. Insufficient $\mathrm{H}_{2} \mathrm{O}_{2}$ dosage will result in a decrease in the organic WW treatment efficiency due to a deficiency of $\mathrm{HO} \cdot$ generated by $\mathrm{H}_{2} \mathrm{O}_{2}$ decomposition under catalysis. On the contrary, excessive $\mathrm{H}_{2} \mathrm{O}_{2}$ dosage is not encouraged either. Firstly, when Fenton-like processes are used for pre-treating high concentration organic WW for the purpose of improving the ratio of BOD (Biochemical Oxygen Demand) to COD (Chemical Oxygen Demand) (BOD/COD or B/C), a massive amount of $\mathrm{H}_{2} \mathrm{O}_{2}$ could have a negative effect on the reactivity of the microorganisms that are used to treat the pretreated organic WW in the subsequent bio-treatment process. Secondly, an excessive $\mathrm{H}_{2} \mathrm{O}_{2}$ dosage would increase the treatment cost significantly when the volume of organic WW is very high. In China the price range of industrial grade $\mathrm{H}_{2} \mathrm{O}_{2} \quad(27.5 \%$, w/w) in recent years is approximately $¥ 1100-1300 /$ ton. Hence the $\mathrm{H}_{2} \mathrm{O}_{2}$ dosage must be in the optimal range. Thirdly, excessive $\mathrm{H}_{2} \mathrm{O}_{2}$ dosage could cause an increase in the COD of the effluent. 
Although this kind of COD cannot pose any harm to the environment, it probably makes the quality of treated WW cannot satisfy the discharge standard because of the innocuous COD. The last, but quite significant, point is that the scavenger effect of $\mathrm{H}_{2} \mathrm{O}_{2}$ on $\mathrm{HO}$ (see reaction equation (2)) would be greater when the $\mathrm{H}_{2} \mathrm{O}_{2}$ dosage is excessive [68-72].

$\mathrm{H}_{2} \mathrm{O}_{2}+\mathrm{HO} \cdot \rightarrow \mathrm{H}_{2} \mathrm{O}+\mathrm{HO}_{2}$.

In the previous studies the required theoretical $\mathrm{H}_{2} \mathrm{O}_{2}$ dosage was calculated [73-75] as for the following example of the reaction between $\mathrm{C}_{\mathrm{a}} \mathrm{H}_{b} \mathrm{~N}_{c} \mathrm{O}_{d}$ and $\mathrm{H}_{2} \mathrm{O}_{2}$ given in reaction equation (3).

$\mathrm{C}_{a} \mathrm{H}_{b} \mathrm{~N}_{c} \mathrm{O}_{d}+\left(2 a+\frac{1}{2} b+\frac{5}{2} c-d\right) \mathrm{H}_{2} \mathrm{O}_{2} \rightarrow a \mathrm{CO}_{2}+(2 a+b+2 c-d) \mathrm{H}_{2} \mathrm{O}_{2}+$ $\mathrm{CHNO}_{3}$

According to reaction equation (3), theoretically one mole of $\mathrm{C}_{\mathrm{a}} \mathrm{H}_{\mathrm{b}} \mathrm{N}_{\mathrm{c}} \mathrm{O}_{\mathrm{d}}$ requires $\left(2 a+\frac{1}{2} b+\frac{5}{2} c-d\right)$ moles $\mathrm{H}_{2} \mathrm{O}_{2}$. So the $\mathrm{H}_{2} \mathrm{O}_{2}$ dosage should be determined by the type of contaminant and the initial concentration of the contaminant. If the $\mathrm{H}_{2} \mathrm{O}_{2}$ dosage is lower than the theoretical value, then theoretically the removal rate of $\mathrm{C}_{\mathrm{a}} \mathrm{H}_{\mathrm{b}} \mathrm{N}_{\mathrm{c}} \mathrm{O}_{\mathrm{d}}$ can never reach $100 \%$. So the actual concentration of $\mathrm{H}_{2} \mathrm{O}_{2}$ added should be higher than the theoretical value and the required amount should be determined by experiment.

Some researchers found that stepwise addition of $\mathrm{H}_{2} \mathrm{O}_{2}$ is a good way to improve the treatment efficiency of a WW. One of the typical studies is by Zhang et al. [76]. In their study, a Fenton-like process was used to treat landfill leachate and stepwise addition of $\mathrm{H}_{2} \mathrm{O}_{2}$ was applied. The study results showed that the stepwise addition of $\mathrm{H}_{2} \mathrm{O}_{2}$ could give a better WW treatment efficiency (15.6\% higher than that for a single step). The more moderate distribution of $\mathrm{H}_{2} \mathrm{O}_{2}$ explains the improved treatment of the WW [77]. Moreover, a delay in the decomposition of $\mathrm{H}_{2} \mathrm{O}_{2}$ is also 
recommended in our review as an explanation for this phenomenon. Firstly, the step-wise addition of $\mathrm{H}_{2} \mathrm{O}_{2}$ can ease off the dramatic increase in the $\mathrm{H}_{2} \mathrm{O}_{2}$ concentration, thus avoiding the side reaction shown in reaction equation (2). Secondly, the step-wise addition of $\mathrm{H}_{2} \mathrm{O}_{2}$ can avoid the rapid decomposition of $\mathrm{H}_{2} \mathrm{O}_{2}$ (especially under alkaline conditions). It is well known that the $\mathrm{pH}$ has a significant effect on the stability of $\mathrm{H}_{2} \mathrm{O}_{2}$, i.e., acidic conditions are beneficial for the stability of $\mathrm{H}_{2} \mathrm{O}_{2}$ while alkaline conditions will accelerate the decomposition of $\mathrm{H}_{2} \mathrm{O}_{2}$. If all of the $\mathrm{H}_{2} \mathrm{O}_{2}$ was added in one step, more $\mathrm{H}_{2} \mathrm{O}_{2}$ could be wasted due to decomposition.

\subsection{Catalyst dosage}

An increase in the catalyst dosage is sometimes beneficial to improve the removal rate of the organics in the WW. However, the catalyst cannot be added without any limitation. The excessive loading of catalyst in both hetero- and homo-geneous Fenton-like processes may have a negative effect during the WW treatment, i.e., the scavenger effect may occur (see equation (4)),

$\mathrm{Fe}^{2+}+\mathrm{HO} \cdot \rightarrow \mathrm{Fe}^{3+}+\mathrm{OH}^{-}$

If the catalyst loading in the aqueous solution exceeded the optimum range, the generated HO. would be consumed by the excess catalyst.

In addition to the above effect, the catalyst loading can present other effects. In heterogeneous Fenton-like processes, the production cost of the solid catalyst could be a limiting parameter in organic WW treatment. Higher catalyst loading would obviously increase the WW treatment cost; in the homogeneous Fenton-like processes the excessive concentration would result in the generation of a large volume of sludge, which would increase the need for subsequent sludge treatment processes. Additionally, it could cause the metal concentration in the effluent to exceed the 
regional discharge standard for the WW, which would cause further problems due to the requirement for subsequent treatment of the effluent.

According to the statement above, optimization of the catalyst loading in both hetero- and homo-geneous Fenton-like processes should be conducted. In addition, for heterogeneous Fenton-like processes the use of catalyst recycling is also recommended depending on the results of a study of its stability.

In heterogeneous Fenton-like processes, the performance of recycled catalyst is affected by the leaching characteristics of the active metal element on the solid catalyst surface, which can result in the deactivation of the heterogeneous catalyst. Zhang et al. [75] used acid-activated fly ash to treat $p$-nitrophenol WW. The experimental results showed that the removal efficiency of $p$-nitrophenol decreased with an increase in the run time, meanwhile leaching of elemental $\mathrm{Fe}$ occurred in all of the experimental runs. A typical stability study result from another paper is shown in Figure 2 [51]. It showed that the removal rate of the contaminant did not decrease obviously even when the catalyst was used five times, i.e., the catalyst can remain stable for five runs.

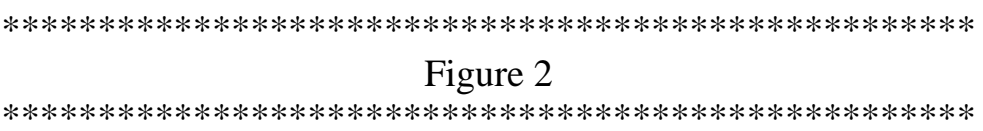

According to the first five tables in this paper, the catalyst loading has no absolute optimum range for a specific kind of Fenton-like process, but still presents some obvious statistical rules, which could be valuable for the determination of catalyst loading. For Fenton-like processes that are not combined with any physical field/phenomenon, the solid catalyst loading is in the range $1-10 \mathrm{~g} \mathrm{~L}^{-1}$ in most studies 
(87.5\%), while $100 \mathrm{~g} \mathrm{~L}^{-1}$ can sometimes also be used; the homogeneous catalyst presents an obvious difference: a catalyst concentration of $20-60 \mathrm{mg} \mathrm{L}^{-1}$ is used when treating the model WW, while a catalyst concentration of $200-500 \mathrm{mg} \mathrm{L}^{-1}$ is necessary for the industrial WW. For a Fenton-like process that is enhanced by a physical field/phenomenon, the solid catalyst loading is obviously decreased in most cases (0.1-5 $\left.\mathrm{g} \mathrm{L}^{-1}, 69.2 \%\right)$, while a lower $\left(\leq 0.05 \mathrm{~g} \mathrm{~L}^{-1}, 11.5 \%\right)$ or higher $\left(10-40 \mathrm{~g} \mathrm{~L}^{-1}, 19.2 \%\right)$ catalyst loading can also be used in some cases.

The homogeneous catalyst presents a similar trend to that of the solid catalyst, i.e., the catalyst concentration is relatively low compared to that of the unenhanced Fenton-like processes; a concentration range of $1.7-28 \mathrm{mg} / \mathrm{L}$ is always used when treating model WW, while a higher concentration (at least $120 \mathrm{mg} / \mathrm{L}$ ) must be used for industrial WW.

\subsection{WW treatment temperature}

WW treatment temperature has a significant effect on the treatment efficiency of organic WW. Although the temperature used for Fenton-like processes is typically around $25-30{ }^{\circ} \mathrm{C}$ [17], the effect of higher temperature was still studied by some researchers due to the existence of some inevitable facts such as (I) textile effluents are usually around $50{ }^{\circ} \mathrm{C}[35,78]$, and (II) higher temperature could be beneficial to reduce the catalyst dosage [79]. When a lower temperature $\left(20-40{ }^{\circ} \mathrm{C}\right)$ was applied, the researchers always have the same viewpoint, i.e., the treatment efficiency can be improved by increasing the temperature, because higher temperatures can provide more energy to overcome the reaction activation energy $[35,62,80]$ and then accelerate the reaction by increasing the reaction rate constant according to the Arrhenius equation [64]. 
However, when a higher temperature $\left(>40^{\circ} \mathrm{C}\right)$ was applied, different conclusions were reached in the different studies. Munoz et al. [81] showed that the TOC (total organic carbon) removal rate for sawmill WW increased obviously with an increase in temperature $\left(50-120{ }^{\circ} \mathrm{C}\right)$ and the $\mathrm{H}_{2} \mathrm{O}_{2}$ utilization efficiency was also increased (15 and $83 \mathrm{mg}$ TOC converted per $\mathrm{g} \mathrm{H}_{2} \mathrm{O}_{2}$ at 50 and $120{ }^{\circ} \mathrm{C}$, respectively) (Figure $3 \mathrm{~A}$ ); Mesquita et al. [17] and Zazo et al. [79] both showed that the conversion of TOC had no obvious variation when the temperature was between 50 and $70{ }^{\circ} \mathrm{C}$ (Figure $3 \mathrm{~B}$ ) and between 110 and $130{ }^{\circ} \mathrm{C}$, respectively; Hashemian [62] showed that the removal rate of Malachite Green can neither keep increasing nor remain constant, but has a decreasing trend with the increase in temperature $\left(30-70{ }^{\circ} \mathrm{C}\right)$ (Figure $\left.3 \mathrm{C}\right)$.

Figure 3

These different conclusions could be associated with the competition between organic degradation by the attack of $\mathrm{HO}$ and by the side reaction (2). With an increase in the temperature, more $\mathrm{HO} \cdot$ can be generated. The reaction rate of organics degradation $\left(\gamma_{1}\right)$ and the side reaction $(2)\left(\gamma_{2}\right)$ can both be accelerated due to higher temperatures. However, the different reaction activation energies $(E)$ between organics and $\mathrm{HO} \cdot$ will result in the different results. According to Arrhenius equation, when $E$ is relatively low, the reaction rate constant $\left(k_{1}\right)$ will have a relatively rapid increase (with the increase in temperature) compared with that of the side reaction (2). However, when $E$ is relatively high, the experiment may show the opposite results.

According to the statement above, although increasing the temperature is always beneficial for the treatment of WW, special attention should be paid when the WW 
temperature is higher than $40{ }^{\circ} \mathrm{C}$. A specific optimum temperature should be determined experimentally as different catalysts could present different performances for the reaction rate of organic degradation.

*****************************************************************

Table 1

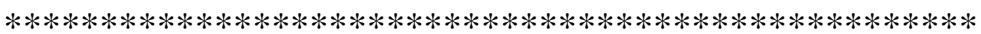

\section{Physical field/phenomenon-assisted Fenton-like processes}

\subsection{Photo-Fenton-like processes}

The role of photochemistry in a Fenton-like process is to provide energy using ultraviolet and/or visible light to reduce the catalyst loading and/or to enhance the catalytic capacity of the catalyst in both heterogeneous and homogeneous Fenton-like processes; the essence is related to the redox processes [88]. In the heterogeneous photocatalytic system, the photo-induced reductive dissolution of the solid catalyst has been accepted by researchers $[89,90]$. In this review, iron oxide is taken as an example to illustrate the proposed mechanism as $\mathrm{Fe}(\mathrm{III})$ oxide have been studied widely. The proposed model of photo-reductive dissolution of $\gamma-\mathrm{FeOOH}$ is shown in Figure 4 [91].

\footnotetext{
***************************************************************

Figure 4

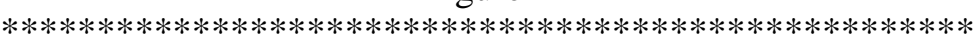

We can see from Figure 4 that a charge transfer process from organic ligand to metal happens after the formation of $\mathrm{Fe}(\mathrm{III})$-organic ligand complexes on the solid phase; in other words, this model illustrates a photo-induced $\mathrm{Fe}(\mathrm{III}) / \mathrm{Fe}(\mathrm{II})$ redox cycle between the solid and aqueous phases. In this model the irradiation of ultraviolet 
and/or visible light promotes the formation and the release of $\mathrm{Fe}^{2+}$ into aqueous phase from the solid surface; this process results in the occurrence of the Fenton process in the presence of $\mathrm{H}_{2} \mathrm{O}_{2}$. Thus, photo-irradiation is the essence of photo-Fenton-like processes.

In addition to the iron-based catalyst, other kinds of transition metal catalyst like the $\mathrm{Cu}$-based catalyst also attracts much attention in organic WW treatment. Kalal et al. [92] and Lam et al. [93] developed copper pyrovanadate and Copper/MCM-41, respectively, to treat organic WW. In the study by Kalal et al. [92] researchers found that copper pyrovanadate had better catalytic capacity than that of $\mathrm{CuO}$ and $\mathrm{V}_{2} \mathrm{O}_{5}$; the shell of the copper pyrovanadate could be the main reason as the copper pyrovanadate can increase the surface hydroxyl groups and enhance the interfacial electron transfer. The study by Lam et al. [93] shows that Copper/MCM-41 was a pH-insensitive catalyst that can overcome the low efficiency issues of the Fenton process under neutral/alkaline conditions. Some of the detailed conclusions regarding organic WW treatment in heterogeneous photo-Fenton-like systems are shown in No. 1-9 in Table 2.

In homogeneous photo-Fenton-like systems the photochemical reduction of the metal catalyst is the main pathway during the catalytic oxidation process. Taking photo- $\mathrm{Fe}^{3+}-\mathrm{H}_{2} \mathrm{O}_{2}$ system as an example, except for the reactions in the $\mathrm{Fe}^{3+}-\mathrm{H}_{2} \mathrm{O}_{2}$ system, two extra reactions can occur due to the existence of photo irradiation. The first reaction involves $\mathrm{Fe}^{3+}$ ions (which exist in the form of $\mathrm{Fe}(\mathrm{OH})^{2+}$ under acidic condition) undergoing a photochemical reduction process to form $\mathrm{Fe}^{2+}$ ions under UV-vis radiation (equation (5)) [92, 94, 95]; the second reaction involves $\mathrm{H}_{2} \mathrm{O}_{2}$ generating $\mathrm{HO} \cdot$ via a photolysis process under shorter wavelength radiation (equation (6)) [94-96]. 
$\mathrm{Fe}(\mathrm{OH})^{2+}+h v \rightarrow \mathrm{Fe}^{2+}+\mathrm{HO} \cdot(\lambda<580 \mathrm{~nm})$

$\mathrm{H}_{2} \mathrm{O}_{2}+h v \rightarrow 2 \mathrm{HO} \cdot(\lambda<310 \mathrm{~nm})$

Photo-generated ferrous ions (equation (5)) can enter the Fenton system directly, produce more $\mathrm{HO}$, and finally improve the removal rate of the organic pollutants (see No. $10-13$ in Table 2).

The photo- $-\mathrm{Fe}^{3+}-\mathrm{H}_{2} \mathrm{O}_{2}$ system always performs well at $\mathrm{pH} 3.0$, where $\mathrm{Fe}$ (III) hydroxyl complexes are more soluble and $\mathrm{Fe}(\mathrm{OH})^{2+}$ is more photoactive [94, 97-100]. When working at higher $\mathrm{pH}(>3)$, an inorganic/organic ligand is always needed (reaction equation (7)) to complex the ferric ion [96, 101]; this can prevent the precipitation of iron ion. The most effective ligands that are used frequently include, but are not limited to: citrate, oxalate, EDTA (ethylene diamine tetraacetic acid), humic acids, EDDS (ethylenediamine disuccinic acid), and catechin.

$F e^{I I I}-L+h v \rightarrow F e^{I I}+L^{+}$

The high yield of $\mathrm{Fe}(\mathrm{II})$ in the presence of ligands increases the amount of HOgenerated under near neutral conditions, thereby improving the removal efficiency of organic pollutants in the WW. Wang et al. [53] used catechin as a ligand to complex $\mathrm{Fe}^{3+}$ ions and the Inderal removal rate can reach to $75 \%$ within $120 \mathrm{~min}$ at $\mathrm{pH}=6.0$ (No. 14 in Table 2).

In addition to the $\mathrm{Fe}^{3+}$-catalyzed homogeneous photo-Fenton-like processes, $\mathrm{Cu}^{2+}$ and $\mathrm{Cu}^{2+}$-complexes can also act as the catalyst (see reaction equations (8) and (9)) in homogeneous Fenton-like processes by photo irradiation under neutral conditions [102]. Some study results are shown in Table 2 (No. 16 and 17).

$C u^{\text {II }} \quad L+h v \rightarrow C u^{I}+L^{+}$.

$\mathrm{Cu}^{+}+\mathrm{H}_{2} \mathrm{O}_{2} \rightarrow \mathrm{Cu}^{2+}+\mathrm{HO} \cdot+\mathrm{OH}^{-}$ 
Finally, the use of soluble bio-organic substances (SBO) as potential photocatalysts has also attracted much attention by researchers in recent years. One of the typical studies is from Gomis's research group [103], where SBO was applied to treat crystal violet $(\mathrm{CV})$. In this study, a mechanism involving the photosensitizer-pollutant complexes (CV-SBO) theory was proposed. According to the study result, $66.7 \%$ discoloration was achieved after a 300 min treatment time at $\mathrm{pH}=7.0$ (see No. 18 in Table 2).

$* * * * * * * * * * * * * * * * * * * * * * * * * * * * * * * * * * * * * * * * * * * * * * * * * * * *$

Table 2

***********************************************************

\subsection{Electro-Fenton-like processes}

Electrochemical processes can be combined with Fenton-like processes (EF-like processes) during WW treatment to improve the Fenton-like processes. A large number of study results have been published in recent years. Sires et al. [110], in their review, offered a global perspective on the experimental setup including laboratory scale and pilot scale equipment based on a general introduction of electro-Fenton-like processes. Brillas [111] introduced electro-Fenton processes in detail and proposed that the oxidation capacity of electro-Fenton processes comes from the attack of $(\mathrm{OH})-\mathrm{O}$-center dot on the anode surface and in the medium where Fenton reaction occurs. In addition, the removal of industrial chemicals, the effect of experimental parameters, the decay kinetics of contaminants, and the corresponding intermediates were discussed. Yu et al. [112], based on the application of Boron-doped diamond, presented the important parameters of the electro-Fenton processes when treating three sorts of bio-refractory organics (pharmaceuticals, pesticides, and dyes). 
Nidheesh and Gandhimathi [113] verified the effectiveness of electrochemical reactions in a bubble column reactor.

For the electro-Fenton-like processes, the source of the oxidant and catalyst is diverse. Firstly, in both hetero- and homo-geneous Fenton-like processes, $\mathrm{H}_{2} \mathrm{O}_{2}$ can be generated in situ via a two-electron reduction of dissolved oxygen on the surface of the cathode in an acidic solution when electrochemical process is applied (reaction equation (10) [114]).

$$
\mathrm{O}_{2}+2 \mathrm{H}^{+}+2 e^{-} \rightarrow \mathrm{H}_{2} \mathrm{O}_{2}
$$

The production of $\mathrm{H}_{2} \mathrm{O}_{2}$ in situ via an electrochemical processes is beneficial for an increase in the organics degradation efficiency, a decrease in the cost, and a reduction in the risks associated with transportation. In addition, in the electro-Fenton-like processes this kind of $\mathrm{H}_{2} \mathrm{O}_{2}$ can also be consumed prior to being decomposed to $\mathrm{H}_{2} \mathrm{O}$ and $\mathrm{O}_{2}$. This property gives higher selectivity for the targeted reactions [115].

Secondly, besides the generation of $\mathrm{H}_{2} \mathrm{O}_{2}$ in situ, a homogeneous metal catalyst $M^{n+}\left(\right.$ such as $\mathrm{Fe}^{2+}, \mathrm{Mn}^{2+}, \mathrm{Cu}^{2+}$, and $\left.\mathrm{Co}^{2+}[40,42,114,116]\right)$ can either be supplied by sacrificing the corresponding metal anode directly or regenerated on the surface of cathode after external addition of metal ion. The reaction for regenerating active metal catalyst on the cathode surface is shown in reaction equation (11).

$$
M^{(n+1)+}+e^{-} \rightarrow M^{n+}
$$

Due to the advantages mentioned above, the EF-like processes has been studied and used widely for the degradation of various organic pollutants, including dyes [117], pesticides [118], amines [119], and phenolic compounds [120].

Actually, homogeneous EF-like processes can be classified into five categories by differentiating the sources of $\mathrm{H}_{2} \mathrm{O}_{2}$ and the catalyst, while the heterogeneous EF-like 
processes is relatively simple (providing the heterogeneous catalyst externally and generating $\mathrm{H}_{2} \mathrm{O}_{2}$ in situ on the surface of cathode by bubbling oxygen/air). The five kinds of homogeneous EF-like processes are as follows [41, 43, 114, 116, 121-128]: (1) Peroxi-Coagulation (PC) process (Figure 5a). In this process, $\mathrm{H}_{2} \mathrm{O}_{2}$ is generated in situ on the cathode surface by bubbling air/oxygen and the metal ion catalyst is provided by a sacrifice anode.

(2) EF-Fere process (Figure 5b). $\mathrm{H}_{2} \mathrm{O}_{2}$ and the metal ion catalyst are both added externally and the metal ion catalyst is regenerated by reduction of the cathode.

(3) Electrochemical Peroxidation (ECP) process (Figure 5c)/Anodic Fenton treatment (AFT) process (Figure 5d). In these two processes, $\mathrm{H}_{2} \mathrm{O}_{2}$ is added externally and the metal ion catalyst is provided by a sacrifice anode. The difference between them simply arises from either using or not using a salt bridge, i.e., the use of undivided or divided cells.

(4) $\mathrm{H}_{2} \mathrm{O}_{2}$ is generated in situ on the cathode surface by bubbling air/oxygen and metal ion catalyst is added externally and regenerated by reduction of the cathode.

(5) $\mathrm{H}_{2} \mathrm{O}_{2}$ is generated in situ on the cathode surface by bubbling air/oxygen and the homogeneous catalyst (including the metal ion catalyst mentioned in the above four items and other soluble catalyst such as $\left.\mathrm{PW}_{11} \mathrm{O}_{39} \mathrm{Fe}(\mathrm{III}) .\left(\mathrm{H}_{2} \mathrm{O}\right) .^{4-}[127]\right)$ is provided externally.

Figure 5

$* * * * * * * * * * * * * * * * * * * * * * * * * * * * * * * * * * * * * * * * * * * * * * * * * * * * * * * *$

EF-like processes has been studied by many researchers and exhibit excellent capacity to treat organic WW. Babuponnusami and Muthukumar [37] applied nano 
zero-valent iron (nZVI) to treat phenol WW (see No. 3 in Table 3) due to the high reactivity of nZVI. When the $\mathrm{pH}$ was $6.2,100 \%$ of the phenol was removed within 30 min. Wang et al. [127] developed a Keggin-type iron-substituted heteropolytungstate anion as the homogeneous Fenton-like catalyst and treated dimethylphthalate WW successfully at pH 6.86 within 80 min (see No. 8 in Table 3). In addition, the use of $\mathrm{NaHCO}_{3}$ was also reported because it can enhance the generation of $\mathrm{HO}$ in the electro-Fenton processes where graphite was used as electrode [129, 130]. To achieve satisfactory WW treatment, Nidheesh et al. [131] presented a typical mechanism for the heterogeneous Fenton-like processes, which is catalysed by magnetite (see Figure 6). Some other typical studies are presented in No. 1, 4-7 in Table 3.

Figure 6

Generally speaking, the EF-like system requires an acidic situation. If the $\mathrm{pH}$ is close to neutral or an alkaline condition exists, the metal catalyst will precipitate from the solution and then the reaction could be terminated or become slower. In order to solve this problem, the development of a kind of composite electrode with catalytic capacity could be a good idea. Liu et al. [115] applied $\mathrm{Co}_{3} \mathrm{O}_{4}$-graphite composite as the electrode to treat organic pollutants in WW (see No. 2 in Table 3). This study showed that the degradation of organics presented $\mathrm{pH}$-independence within a wide range of $\mathrm{pH}(2.0-10.0)$. 


\subsection{Cavitation-Fenton-like processes}

Two kinds of cavitation can be used in WW treatment, i.e., acoustic cavitation and hydrodynamic cavitation. Acoustic cavitation is always generated by the passage of high frequency sound waves, i.e., ultrasonic (US), whereas hydrodynamic cavitation can occur when the pressure varies in the fluid due to a sudden change in the linear flow rate of the fluid $[133,134]$.

Cavitation provides an effective alternative to degrade organics. The formation of cavitation microbubbles is the direct trigger. The microbubbles can grow continuously until they reach a critical size, which can cause a violent implosive collapse. The rapid implosion of cavitation bubbles is followed by a localized extremely high temperature and high pressure of about $5000{ }^{\circ} \mathrm{C}$ and 500 atm, respectively [135-137]. Under this kind of extreme conditions water can be transformed into different oxidizing species via pyrolysis, such as $\mathrm{H} \cdot \mathrm{HO} \cdot \mathrm{HO}_{2}^{-}$, and $\mathrm{H}_{2} \mathrm{O}_{2}[44,138]$. A typical scheme for acoustic cavitation and an ultrasonic-Fenton/Fenton-like system are shown in Figure 7 and Figure 8, respectively. The hydrodynamic cavitation can be generated by the orifice plate and/or slit venturi at the laboratory scale [133, 134, 137].

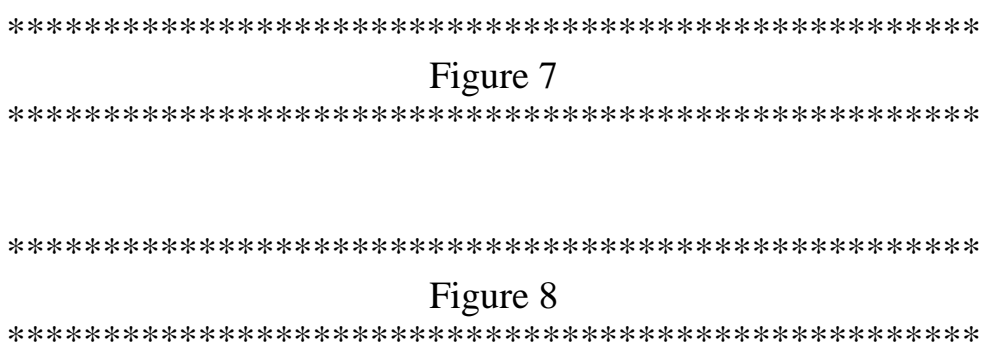

In the liquid-solid system, however, the mechanism of enhancing Fenton-like processes by the cavitation bubbles is different from that in the homogeneous system mentioned above. First of all, the energy needed to produce cavity nucleation is lower 
due to the existence of the solid-liquid interface [140]. Secondly, microjet impact and shockwave damage [136] near the solid surface can occur when the cavitation bubbles collapse. In the case of microjet impact, the asymmetry environment near the solid surface makes the cavitation bubbles collapse dissymmetrically, resulting in a fast-moving stream of liquid toward the solid surface with velocities $>100 \mathrm{~m} / \mathrm{s}$. The microjets hit the surface of the solid with enormous force, resulting in the activation of the surface of the catalyst. In the case of shockwave damage, the enhancement effect involves the damage of shock waves generated by cavitation bubbles collapsing near the solid surface in the liquid phase.

In organic WW treatment, in order to combine the advantages of cavitation and a Fenton-like process, they must be applied together. The enhancement effect of cavitation to Fenton-like processes in homogeneous and heterogeneous systems are different. In the homogeneous system the extremely high temperature and the presence of oxidizing species generated by cavitation are the main reasons for this enhancement, while in the heterogeneous system the activation effect of the cavitation on the surface of solid catalyst could be the main mechanism. Zhou et al. [141] showed that cavitation could play an acceleration role when combined with the $\mathrm{UV} / \mathrm{Fe}_{3} \mathrm{O}_{4} /$ oxalate system. Huang et al. [142] applied $\mathrm{Fe}_{3} \mathrm{O}_{4}$ nanoparticles as well as a heterogeneous catalyst to treat bisphenol A (BPA). The study results showed that $\mathrm{Fe}_{3} \mathrm{O}_{4}$ nanoparticles performed a better activity in the cavitation- $\mathrm{Fe}_{3} \mathrm{O}_{4}-\mathrm{H}_{2} \mathrm{O}_{2}$ system than that in the $\mathrm{Fe}_{3} \mathrm{O}_{4}-\mathrm{H}_{2} \mathrm{O}_{2}$ system; $\mathrm{BPA}$ can be degraded in a wide $\mathrm{pH}$ range. In addition, $\mathrm{Fe}_{3} \mathrm{O}_{4}$ nanoparticles can be used as many as 5 times while still maintaining good stability and activity. Some other studies associated with the cavitation-Fenton-like processes have been summarized in Table 4. 
Table 4

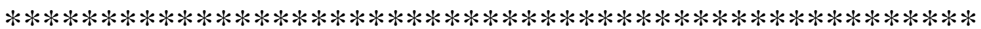

\subsection{Microwave-(another physical field)-Fenton-like processes}

Microwave (MW) radiation is a wavelength band of the electromagnetic spectrum with frequencies ranging from $300 \mathrm{MHz}$ to $300 \mathrm{GHz}[74,151]$. Only frequencies of 2450 and $915 \mathrm{MHz}$ are permitted for use in non-military applications. MW has attracted much attention in organic WW treatment because of its unique heating mode. MW irradiation can penetrate many lossy media (such as water, transition metal oxides, and activated carbon). When dipole molecules are subjected to a MW field, rotation of the dipoles occurs immediately but cannot adequately follow the direction variation rate of the MW field. This causes a time delay and then causes a huge amount of energy to be consumed, which is expressed by thermal effects [152, 153]. Due to the non-uniformity of MW irradiation, "hot spots" can be generated on the surface of the MW absorbent; this is an extremely important feature of MW radiation as chemical reactions can be enhanced by the "hot spots" effect. Another important feature, namely the non-thermal effect, cannot be ignored either. This refers to other effects besides the thermal effect, including the chemical effect, electrical effect, and magnetic effect [154-156].

The combination of MW irradiation with the Fenton-like processes has shown obvious superiority compared with the Fenton-like process alone. As shown in Table 5, within a relatively short reaction time $(\leq 7 \mathrm{~min})$ when compared with the Fenton-like process alone (see Table 1), many kinds of organic WW have been treated effectively in both MW-assisted homo-/hetero-generous Fenton-like processes. In the MW-assisted heterogeneous Fenton-like processes (No. 1-3 in Table 5), we find that 
the catalyst can always be reused several times (even at least 8 times, with the leaching of a small amount of catalyst (No. 3 in Table 5)).

In addition to the combination of the Fenton-like process with the single MW field mentioned above, the combination of the Fenton-like process with two kinds of physical fields (including the MW field) was also studied. However, this kind of study has not attracted enough attention by researchers; only a minority of studies were conducted. First of all, MW irradiation has shown a positive effect on electro-Fenton-like processes by accelerating the reduction of $\mathrm{Fe}(\mathrm{III})$ to $\mathrm{Fe}$ (II). The possible reason was that "hot spots" could be generated on the surface of the electrode under microwave irradiation. These high temperature shear forces can be helpful to promote the transduction of electrons to the cathode surface, and then accelerate the Fe(III) reduction. Wang et al. [114] showed that under MW irradiation, more HO can be generated in the MW-electron-Fenton-like processes, which was 2.3 times higher than that in the absence of MW irradiation.

Furthermore, another representative work is the combination of microwave radiation with photochemistry to improve the WW treatment efficiency. In the homogeneous Fenton-like processes, the MW-UV system could generate more HOvia reaction equation (6). The proposed reason is that after the absorption of MW radiation each $\mathrm{H}_{2} \mathrm{O}_{2}$ molecule can be activated and then divided into two $\mathrm{HO}$. more easily. In heterogeneous Fenton-like processes, it was found that MW irradiation could obviously enhance the photocatalytic activity of a catalyst with a high defect density by the polarization effect, i.e., MW radiation can promote the transition of electrons excited by photons to the catalyst surface and then decrease the possibility of recombination of the electron-hole pair [157]. 
The combination of UV and MW irradiation can be realized conveniently by the use of MW electrodeless ultraviolet (MWEUV) lamp, which has been used in organic photochemistry since 1999 [158]. A MWEUV lamp is a glass cavity that is filled with an excitable substance (usually a metal) and an inert/noble gas and then sealed under a low-pressure condition $(0.266-2.66 \mathrm{kPa})$. Under MW irradiation, the inert gas in the glass cavity can be ionized by the collision of accelerated electrons (separated from the environment by the ambient energy), and then more electrons will be released by the collision over a short period of time. After that, the huge number of electrons released can excite the metal atoms inside the cavity to higher energy levels, and finally, UV/visible light is emitted when the excited metal atoms return to the ground state [159]. A typical MW-UV-Fenton-like process is shown in Figure 9. In this process, the MWEUV lamp was immersed in the reaction system and then excited by the MW irradiation. The MW-UV-Fenton-like process started after the MWEUV lamp was illuminated.

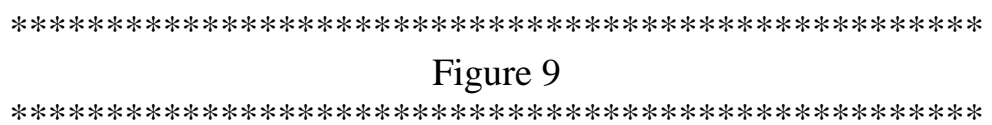

Some studies associated with the MW-photo-Fenton-like processes were conducted by Liao et al. [161, 162]. In these studies, researchers developed two photo-catalysts, i.e., $\mathrm{ZrO}_{\mathrm{x}}$ and $\mathrm{ZrO}_{\mathrm{x}} / \mathrm{ZnO}$, to treat organic pollutants in the $\mathrm{WW}$. When $\mathrm{ZrO}_{\mathrm{x}}$ or $\mathrm{ZrO}_{\mathrm{x}} / \mathrm{ZnO}$ was used as catalyst, the study results showed better catalytic capacity when compared with that of $\mathrm{P} 25 \mathrm{TiO}_{2}$. Under the optimal conditions, the TOC removal rates of dimethyl phthalate (DMP) in WW were at least $84 \%$ when $\mathrm{ZrO}_{\mathrm{x}}$ or $\mathrm{ZrO}_{\mathrm{x}} / \mathrm{ZnO}$ was used, which is at least $11 \%$ higher than that of $\mathrm{P} 25 \mathrm{TiO}_{2}$. In 
addition, the degradation half-time of DMP was also shortened obviously (45\%). The proposed mechanism for the high activity of $\mathrm{ZrO}_{\mathrm{x}}$ could be attributed to the co-existence of three $\mathrm{Zr}$ oxides with different valences. This would induce higher electron and hole mobility under MW irradiation.

\section{Table 5}

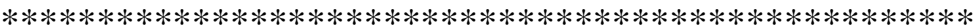

\section{Catalyst types studied in hetero-/homo-geneous Fenton-like processes}

\subsection{Heterogeneous catalyst from natural minerals}

In heterogeneous Fenton-like processes natural mineral materials with special crystal structures or properties have been studied as excellent alternative catalysts because of their high catalytic activities and long-term stabilities [166]. Fenton-like processes using mineral materials as the catalyst are called mineral-catalyzed Fenton-like processes and most of the catalysts used are natural iron-bearing mineral materials, such as schorl $[35,80,82,83]$, goethite $(\alpha-\mathrm{FeOOH})[167,168]$, pyrite $\left(\mathrm{FeS}_{2}\right)$ [61], hematite $\left(\alpha-\mathrm{Fe}_{2} \mathrm{O}_{3}\right)$ [169, 170], magnetite $\left(\mathrm{Fe}_{3} \mathrm{O}_{4}\right)$ [131, 171, 172], ferrihydrite [173], and lepidocrocite [105]. Garrido-Ramirez et al. [174] have given a detailed introduction on the application of iron-oxide minerals in their review (while clays-based and nano catalysts are also introduced), which is helpful to improve our understanding of the catalysts associated with the natural mineral.

Generally speaking, there are four advantages when iron-bearing minerals are applied as the catalyst: (I) the catalyst can be removed from the treated WW easily by sedimentation and/or filtration; (II) the catalyst life can be extended by recycling the catalyst from the treated WW; (III) the initial $\mathrm{pH}$ of the WW could be extended into 
the neutral range (such as $\mathrm{pH} 5-9$ ); (IV) the reaction system is not affected much by inorganic carbonate [175].

Tourmaline is a kind of complex borosilicate mineral and has the trigonal space group $\mathrm{R} 3 \mathrm{~m}$ [176]. The general formula of tourmaline may be written as $\mathrm{XY}_{3} \mathrm{Z}_{6}$ $\left[\mathrm{T}_{6} \mathrm{O}_{18}\right]\left[\mathrm{BO}_{3}\right] \mathrm{V}_{3} \mathrm{~W}$, where $\mathrm{X}=\mathrm{Ca}, \mathrm{Na}, \mathrm{K}$ or vacancy; $\mathrm{Y}=\mathrm{Li}, \mathrm{Mg}, \mathrm{Fe}^{2+}, \mathrm{Mn}^{2+}, \mathrm{Al}, \mathrm{Cr}^{3+}$, $\mathrm{V}^{3+}$, or $\mathrm{Fe}^{3+} ; \mathrm{Z}=\mathrm{Mg}, \mathrm{Al}, \mathrm{Fe}^{3+}, \mathrm{V}^{3+}$, or $\mathrm{Cr}^{3+} ; \mathrm{T}=\mathrm{Si}$ or $\mathrm{Al} ; \mathrm{B}=\mathrm{B} ; \mathrm{V}=\mathrm{OH}$ or $\mathrm{O}$; and $\mathrm{W}=\mathrm{OH}$, $\mathrm{F}$, or $\mathrm{O}[177,178]$. Members of the tourmaline group of minerals can be classified according to which metal element occupies the place of $\mathrm{Y}$, such as schorl $\left(\mathrm{Y}=\mathrm{Fe}^{2+}\right)$, dravite $(\mathrm{Y}=\mathrm{Mg})$, tsilaisite $(\mathrm{Y}=\mathrm{Mn})$, olenite $(\mathrm{Y}=\mathrm{Al})$, and elbaite ( $\mathrm{Y}=\mathrm{Li}, \mathrm{Al})$ [179]. The basic structural units are hexagonal rings of $\mathrm{T}_{6} \mathrm{O}_{18}$ that form the basal plane and are connected with $\mathrm{Na}, \mathrm{Li}$, and $\mathrm{Al}$ octahedra and distorted $\mathrm{BO}_{3}$ groups in planar coordination along [0001] with a three-fold symmetry structure [180]. Tourmaline can generate an electrostatic charge when it is subjected to a tiny pressure and/or temperature variation. The previous study, which uses the model predictions method, has shown that organic compound oxidation rates in mineral-catalyzed Fenton-like systems were improved when electrostatic effects were taken into account [171]. Hence, the electrostatic charge generated by tourmaline would have a reinforcement capacity for the Fenton-like reaction.

Schorl, one kind of well-known mineral of the tourmaline group, has been studied widely as a heterogeneous catalyst in organic WW treatment. In addition to its natural property of bearing iron, the characteristics of pyroelectricity and piezoelectricity are also rather attractive [181], which can improve the catalysis process in the Fenton-like processes. As shown in No. 1-4 in Table 1, two kinds of azo dye (Argazol Blue and Rhodamine B) WW were studied using schorl as the heterogeneous catalyst. We can see that the treatment time would be shorter when more schorl catalyst is used; a 
discoloration rate of more than $98 \%$ was achieved within 4 min when the catalyst dosage was at least $10 \mathrm{~g} / \mathrm{L}$. In addition, the $\mathrm{pH}$ values shown in No. 1-4 in Table 1 are all the optimum $\mathrm{pH}$ value in the cited papers. Although all of the studies were conducted under acidic situations, organic pollutants can actually also be treated effectively under neutral conditions, which are illustrated clearly in these studies.

Besides the tourmaline group, many other iron-bearing mineral materials are also used in WW treatment. Pyrite can always be found in the vicinity of coal and metal ore mines [182]. As an iron sulphide mineral, pyrite has a high reactivity capacity due to its high specific surface area and porosity, which makes pyrite susceptible to being oxidized by an oxidant $\left(\mathrm{H}_{2} \mathrm{O}_{2}, \mathrm{Fe}^{3+}\right.$, and $\mathrm{O}_{2}$, etc. $)$ [36]. Goethite is the most common form of iron oxide mineral that can be found in the oxic soils of temperate regions. Its ubiquity and high catalytic activity enable it to be a useful, naturally-occurring catalyst in Fenton-like systems for the treatment of contaminated soils and groundwater systems [170]. Hematite is a kind of accessory mineral that is distributed in many kinds of rock. The iron content in hematite could be more than $70 \%$, so it is an important kind of iron ore. Magnetite is one of the most stable mixed-valence oxides $\left(\mathrm{Fe}^{2+}-\mathrm{Fe}^{3+}\right)$ at ambient temperature, and it is the most abundant in natural settings [101]. After modification, all of the ores mentioned above can be used as effective heterogeneous Fenton-like catalysts. According to the study results, more than $50 \%$ mineralization, a $70 \%$ COD removal rate, and more than $90 \%$ discoloration/ degradation were achieved (see No. 5 in Table 1, No. 1, 2 in Table 2, and No. 2, 3 in Table 4) within 2 hours.

4.2 Heterogeneous catalyst from composite by artificial synthesis

Many composites have been studied for use as heterogeneous catalysts in Fenton-like processes, such as $\mathrm{Fe}^{2+} / \mathrm{AC}$ [17], $\alpha-\mathrm{Fe}_{2} \mathrm{O}_{3} / \mathrm{S}$ [106], $\mathrm{CuO} / \mathrm{Al}$ [47], 
$\mathrm{Fe}^{2+} /$ Magnetic NdFeB-AC [51], layered Fe-titanate [108], FeOOH-C [84], Iron(III)-alginate fiber [107], Iron oxide/ $\mathrm{SiO}_{2}$ [60], $\mathrm{Cu} / \mathrm{MCM}-41$ [93], iron-loaded mangosteen [183], $\mathrm{TiO}_{2} /$ glass sphere [184] and the magnetite-based catalysts [172]. They can be synthesized by the impregnation method [17, 47, 84, 105, 107], the combination of impregnation and negative pressure [51], hydrothermal treatment [106], the combination of hydrothermal treatment and ion exchange [108], and the MOCVD (metallorganic chemical vapour deposition) technique [93], etc. The application of a composite makes it possible to reuse the active metal element because of the composite's property of being easily separated from treated WW by means of the precipitation method. This could reduce the cost of WW treatment as mentioned in Section 2.3.

Considering clay-based catalysts as an example, clay has been used widely as a catalyst support because it is relatively cheap when compared with other catalyst supports. Many kinds of clay-based catalyst were developed in recent years, such as Fe/laponite [185], montmorillonite [186], Cu-Al/montmorillonite [187], and $\mathrm{Fe} /$ bentonite [188]. In these studies, the organic pollutants in WW were treated effectively (pollutant removal rate $>95 \%$ and TOC removal rate $\geq 45 \%$ ) under the optimum operating conditions.

In addition to clay-based catalysts, other kinds of catalyst can exhibit excellent catalytic performances as well. As shown in previous studies (No. 6-9 in Table 1, No. 3-6, 9 in Table 2, and No. 2 in Table 5), many bio-refractory contaminants (Chicago Sky Blue, Methyl Orange, Reactive Red, Rhodamine 6G, Reactive Organic 29, aniline, and $m$-nitrophenol, etc.) have been eliminated effectively (70\%-97\% removal rate of pollutants, at least $70 \%$ TOC removal rate) at the optimum treatment time (3-160 $\mathrm{min}$ ) by the composite-catalysed Fenton-like processes. 
However, we should pay attention to the effect of the support on the catalytic activity. Supports with highly porous natures, high stabilities, and large surface areas are preferable. The supports used frequently in recent years include, but are not limited to: clay, activated carbon, zeolite, silica, fibers, alumina, fly ash, and magnetite. Navalon et al. [189] gave a specific and detailed discussion of the effect of the clay's structure in their review paper, while Nidheesh [190] presented a clear introduction of heterogeneous Fenton-like catalysts used in WW treatment in a wide range of WW treatment processes.

Sometimes a composite material can also act as a catalyst in the form of an electrode. In recent years, cobalt oxide $\left(\mathrm{Co}_{3} \mathrm{O}_{4}\right)$ has attracted much interest due to its unique physical and chemical properties. Research has showed that the $3 \mathrm{~d}$ orbitals of the Co ions displayed a significant catalytic effect in a Fenton-like system [115]. According to this property, Liu et al. [115] developed a novel composite electrode by pressing $\mathrm{Co}_{3} \mathrm{O}_{4}$ and graphite together. The $\mathrm{Co}_{3} \mathrm{O}_{4}$-graphite composite electrode displayed excellent electrochemical characteristics and can produce $\mathrm{H}_{2} \mathrm{O}_{2}$ and HO within a wide $\mathrm{pH}$ range (2-10). Meanwhile, the target pollutants (sulforhodamine B and 2, 4-dichlorophenol) were both degraded effectively (more than $98 \%$ of removal rate) under the optimum reaction conditions (see No. 2 in Table 3).

\subsection{Heterogeneous catalyst from nano materials}

Nano materials have attracted the attention of many researchers in WW treatment field due to their large surface areas, which is the important and special feature of nano materials. The large surface area makes nano materials exhibit many advantages in the chemical catalysis field, such as low diffusion resistance, easy accessibility to reactants, and a large number of active sites [45]. They can be synthesized by several common methods, such as chemical co-precipitation [45, 191, 192], the hydrothermal 
method [193], and different physical assistant methods (including the Langmuir-Blodgett technique [194], $\gamma$-ray radiation [195], and microwave irradiation [196]).

In the WW treatment field, many kinds of organic pollutant have been degraded effectively in the nano material-catalyzed Fenton-like processes. There are many kinds of nano material, including, but not limited to: nano zero-valent iron (nZVI) [37, $38,147,197]$, nano $\alpha-\mathrm{Fe}_{2} \mathrm{O}_{3}$, nano $\mathrm{CuO}$ [45], nano-ferroferric [142]. Nano zero-valent iron, as the typical catalyst used in organic WW treatment, can remain in suspension and produce $\mathrm{HO}$ - effectively by corroding its surface in an aqueous solution because of its nano size and large specific surface area. We can see from No. 7 in Table 2, No. 3 in Table 3, and No. 6 in Table 4 that organic pollutants (such as petroleum hydrocarbon, phenol, and 1-alkyl-3-methylimidazolium bromides) were all removed significantly within 30-120 $\min (>90 \%)$.

Besides nZVI, Huang et al. [142] applied ferroferric oxide nanoparticles to treat bisphenol A WW. In this study, $96 \%$ of the bisphenol A and $45 \%$ of the TOC were removed within $480 \mathrm{~min}$ (see No. 8 in Table 4). Elshafei et al. [45] used nano $\alpha-\mathrm{Fe}_{2} \mathrm{O}_{3}$ and nano $\mathrm{CuO}$ particles to treat nitrobenzene WW. The experimental results showed that nano $\alpha-\mathrm{Fe}_{2} \mathrm{O}_{3}$ performed better than nano $\mathrm{CuO}$ particles. Nitrobenzene was removed completely after reaction times of 15 and 25 min when nano $\alpha-\mathrm{Fe}_{2} \mathrm{O}_{3}$ and nano $\mathrm{CuO}$ particles were applied, respectively (see No. 9 in Table 4). Hu et al. [191] synthesized a $\mathrm{Bi}_{2} \mathrm{Fe}_{4} \mathrm{O}_{9}$ single-crystalline catalyst, which can be photoexcited by visible light. Under its catalysis $73 \%$ of the bisphenol A was removed in this study. These excellent performances in organic WW treatment could allow nano materials to be extended to become a potential alternative type of heterogeneous Fenton-like catalyst. 


\subsection{Heterogeneous catalyst from industrial waste}

Fly ash is a fine powder-like solid waste that is produced from modern power stations and steel mills. It is usually discarded as an industrial waste and the annual production of coal fly ash is at least 200 million tonnes globally [75, 149]. Coal fly ash consists totally of the noncombustible matter in coal and a small amount of carbon remaining from incomplete combustion of the combustible matter. According to the detection result of X-ray fluorescence spectroscopy, we know that the detailed components of coal fly ash include $\mathrm{SiO}_{2}, \mathrm{CaO}, \mathrm{Al}_{2} \mathrm{O}_{3}, \mathrm{Fe}_{2} \mathrm{O}_{3}, \mathrm{MgO}, \mathrm{K}_{2} \mathrm{O}, \mathrm{P}_{2} \mathrm{O}_{5}, \mathrm{Na}_{2} \mathrm{O}$, $\mathrm{SrO}, \mathrm{ZrO}_{2}$, and $\mathrm{ZnO}$. [75]. In the past several decades, due to the complex composition of coal fly ash, it has been applied in the construction field only. According to statistical results [198], most coal fly ash was used in the production of cement and concrete in many countries and a small part of the coal fly ash was used to produce aerated/nonaerated block, brick, and structural fill, etc. Although the above applications of coal fly ash are successful, there is still a huge amount of fly ash (70\%-75\%) that is unused and that causes serious environmental problems when it is merely disposed in landfills and/or storage lagoons [75, 149]. Hence, exploring new application methods of coal fly ash appears to be rather urgent to enable the effective treatment of coal fly ash.

In recent years, due to the fact that it possesses a porous surface and active metal elements (such as the iron element), fly ash has been explored for use in the heterogeneous Fenton-like processes. The study results (see No. 10 in Table 1 and No. 10-12 in Table 4) show that organic contaminants have been removed effectively in the coal fly ash-catalyzed heterogeneous Fenton-like processes. At least $85 \%$ of the pollutants are degraded under optimum experimental conditions. 
In addition to coal fly ash, the use of acid mine drainage sludge was also reported [41] as a heterogeneous catalyst in the electrochemical processes after treatment by incineration and grinding. Alginate gel beads were selected as supports to immobilize AMDS (acid mine drainage sludge) and avoid leaching of the metal from the AMDS when operating under acidic conditions. Lissamine Green B and pirimicarb were both degraded effectively within $60 \mathrm{~min}$ and $180 \mathrm{~min}$, respectively, under optimum experimental conditions (see No. 1 in Table 3). These good study results indicate that a potential application exists for industrial waste containing a high metal content in organic WW treatment. This would be beneficial for both environmental protection and to reduce economic concerns.

\subsection{Homogeneous Fenton-like catalyst}

In the homogeneous Fenton-like processes, the catalysts used in the Fenton-like processes include $\mathrm{Fe}^{3+}, \mathrm{Cu}^{2+}, \mathrm{Mn}^{2+}, \mathrm{Co}^{2+}$, and $\mathrm{Ag}^{+}[42,46,67,87]$. Sometimes organic or inorganic ligands are also used for complexing and stabilizing the metal ion (such as $\mathrm{Fe}^{3+}$ ) over a wide $\mathrm{pH}$ range. The ligands studied include, but are not limited to: citrate, oxalate, EDTA, humic acids, and EDDS [199-204]. Under radiation of UV or visible light, the stabilized metal ion (especially the $\mathrm{Fe}^{3+}$ ion) can be reduced easily, which is helpful to generate more $\mathrm{HO}$.

Taking $\mathrm{Fe}^{3+}$ as an example, a large number of studies about the $\mathrm{Fe}^{3+}$-catalyzed Fenton-like processes for the treatment of organic WW have been reported (Table 1-4, Table 5). Many types of organic WW (dyes, antibiotic, nitrobenzene, textile, sawmill WW, etc.) have been treated effectively. At least $90 \%$ pollutant removal rate, at least 80\% COD removal rate, and at least 50\% TOC removal rate are always achieved in the presence or absence of a physical field. 
In addition to $\mathrm{Fe}^{3+}, \mathrm{Cu}^{2+}$ and $\mathrm{Mn}^{2+}$ also move to the forefront as homogeneous catalysts in the Fenton-like processes. The basic mechanism of the $\mathrm{Cu}^{2+}$-catalyzed Fenton-like processes has been shown to be as follows [95]:

$$
\begin{aligned}
& \mathrm{Cu}^{2+}+\mathrm{H}_{2} \mathrm{O}_{2} \rightarrow \mathrm{Cu}^{+}+\mathrm{HO}_{2} \cdot+\mathrm{H}^{+} \\
& \mathrm{HO}_{2} \cdot \leftrightarrow \mathrm{O}_{2}^{-} \cdot+\mathrm{H}^{+} \\
& \mathrm{Cu}^{2+}+\mathrm{O}_{2}^{-} \cdot \leftrightarrow \mathrm{Cu}^{+}+\mathrm{O}_{2} \\
& \mathrm{Cu}^{2+}+\mathrm{HO}_{2} \cdot \leftrightarrow \mathrm{Cu}^{+}+\mathrm{O}_{2}+\mathrm{H}^{+} \\
& \mathrm{Cu}^{+}+\mathrm{H}_{2} \mathrm{O}_{2} \rightarrow \mathrm{Cu}^{2+}+\mathrm{HO} \cdot+\mathrm{OH}^{-}
\end{aligned}
$$

The main mechanism of the $\mathrm{Mn}^{2+}$-catalyzed Fenton-like processes in terms of the electrochemistry is as follows [42]:

$$
\begin{aligned}
& \mathrm{Mn}^{2+}+\mathrm{H}_{2} \mathrm{O}_{2}+\mathrm{H}^{+} \rightarrow \mathrm{Mn}^{3+}+\mathrm{H}_{2} \mathrm{O}+\mathrm{HO} \\
& \mathrm{Mn}^{3+}+e^{-} \rightarrow \mathrm{Mn}^{2+}
\end{aligned}
$$

Iboukhoulef et al. [87] applied the $\mathrm{Cu}^{2+}-\mathrm{H}_{2} \mathrm{O}_{2}$ Fenton-like process to treat phenolic compounds in olive mill WW (see No. 21 in Table 1). A $43 \%$ and $62 \%$ phenolic compound removal rate was achieved when the reaction temperatures were 30 and $50{ }^{\circ} \mathrm{C}$, respectively. Lee et al. [95] also applied the $\mathrm{Cu}^{2+}-\mathrm{H}_{2} \mathrm{O}_{2}$ Fenton-like process to degrade two pharmaceutical compounds in the presence of UV light (see No. 16 in Table 2). Under the optimum reaction parameters a $47 \%$ diclofenac removal rate and a $66 \%$ carbamazepine removal rate were achieved within 240 min. Balci et al. [42] treated glyphosate and aminomethylphosphonic acid (AMPA) using the electro-Fenton-like processes with $\mathrm{Mn}^{2+}$ as the catalyst (see No. 7 in Table 3). The experimental results showed that $95 \%$ of the glyphosate and $100 \%$ of the AMPA were removed within $60 \mathrm{~min}$ and $360 \mathrm{~min}$, respectively.

In addition, for the $\mathrm{Fe}^{3+}$-catalyzed Fenton-like processes, some improved methods were also studied. Firstly, researchers found that $\mathrm{Mn}^{2+}$ can also act as the intensifying 
element in the $\mathrm{Fe}^{3+} / \mathrm{H}_{2} \mathrm{O}_{2}$ process in addition to acting as the catalyst in the electrochemical processes. Zhao et al. [86] added the $\mathrm{Mn}^{2+}$ ion into the $\mathrm{Fe}^{3+} / \mathrm{H}_{2} \mathrm{O}_{2}$ oxidation system to degrade benzoic acid and achieved satisfactory treatment results. $100 \%$ of the benzoic acid and $47 \%$ of the TOC were removed within 25 min and 180 min, respectively (see No. 20 in Table 1). Zhao et al. [86] found that when $\mathrm{Mn}^{2+}$ was added, the reactions posed by the addition of $\mathrm{Mn}^{2+}$ could have an effect on the chain propagation processes of the Fenton-like system; i.e., introduce manganese species with other valences and, correspondingly, additional reactions, which would finally improve the WW treatment efficiency.

Secondly, Wang et al. [127] used a Keggin-type iron-substituted heteropolytungstate anion $\mathrm{PW}_{11} \mathrm{O}_{39} \mathrm{Fe}(\mathrm{III})\left(\mathrm{H}_{2} \mathrm{O}\right)^{4-}$ as the catalyst to substitute for $\mathrm{Fe}^{3+}$ in the Electro-Fenton-like system for the treatment of dimethylphthalate WW. The study shown that the organic WW is treated successfully; $100 \%$ of the dimethylphthalate and $56 \%$ of the TOC were removed when reaction time was 80 min and 120 min, respectively (see No. 8 in Table 3). These aforementioned improvement methods provide some interesting ideas for the enhancement of the homogeneous Fenton-like processes.

4.6 Study status of the catalyst based on different metal elements and the corresponding WW treatment efficiency

According to Tables 1-5, some typical metal elements (Fe, $\mathrm{Cu}, \mathrm{Mn}, \mathrm{Ag}, \mathrm{Co}$, etc.) have been applied as either the important component of the heterogeneous catalyst or the homogeneous catalyst. However, not all the metal elements mentioned above can attract enough attention from researchers. The catalysts based on the Fe element have been studied widely, taking up the maximum percentage $(84.4 \%)$ of the studies in Table 1-5, while the $\mathrm{Cu}$ element has the second greatest percentage (10.9\%) (which is 
far below the percentage for the Fe element). However, the catalytic capacities of the $\mathrm{Mn}, \mathrm{Ag}$, and Co elements only attracted the attention of a minority of the researchers (No. 7 in Table 3 for the Mn element; No. 14 in Table 4 for the Ag element; No. 2 in Table 3; and No. 14 in Table 4 for the Co element).

For the Fe-based catalytic system, the average treatment efficiencies calculated from Tables 1-5 are 94.9\% for initial pollutants and 76.2\% for COD (or TOC), while the maximum removal rate is $100 \%$ for both initial pollutants and COD and the minimum removal rate is $66 \%$ for the initial pollutants and $37 \%$ for TOC. A percentage removal rate of at least $90 \%$ accounts for $84.3 \%$ of the initial pollutants and $38.5 \%$ for the COD (or TOC). However, for the Fenton-like system based on the catalyst containing other kinds of metal element, the data for WW treatment efficiency cannot have an obvious representation because the small amount of data has no statistical significance (due to the small number of studies mentioned above). Thus, in light of the above statistical analysis, we find that the catalysts based on other metal elements (except for the Fe element) still need more attention. Some new kinds of catalyst that have been explored can show excellent catalytic performances (such as No. 2 and 7 in Table 3), which are similar to those of the Fe element. In addition, exploring new catalysts based on multiple kinds $(\geq 2)$ of metal elements could be a new research direction as different metal elements could have synergistic effect during catalytic activity [205].

\section{Cost evaluation}

The wastewater treatment costs of Fenton-like processes can be affected by some significant factors that relate to $\mathrm{H}_{2} \mathrm{O}_{2}$ (source and dosage), the catalyst (source, modification/preparation, activity, and stability), the wastewater (nature of organics, removal level, and concentration), the combination of the Fenton-like process with 
other WW treatment technologies, and the input energy if physical file/phenomenon are/is used. Studies have been conducted to reduce the WW treatment costs relating to one or more of the aspects mentioned above. Since these experimental conditions can be vastly different for each of the research groups, the direct comparison of WW treatment cost is really difficult. Thus, we will discuss the experimental conditions individually in different sections.

\subsection{Effect of parameters associated with $\mathrm{H}_{2} \mathrm{O}_{2}$}

The $\mathrm{H}_{2} \mathrm{O}_{2}$ dosage and/or the source of the $\mathrm{H}_{2} \mathrm{O}_{2}$ have a significant effect on the WW treatment cost. As mentioned in Section 2.2, the investment on $\mathrm{H}_{2} \mathrm{O}_{2}$ must be considered because of its high price. In addition to the optimization of $\mathrm{H}_{2} \mathrm{O}_{2}$ dosage that is conducted in the studies, the feeding mode of $\mathrm{H}_{2} \mathrm{O}_{2}$ should also be investigated because of its potential to reduce the $\mathrm{H}_{2} \mathrm{O}_{2}$ dosage $[76,206,207]$. In the study by Zhang et al. [76] researchers found that, at the same total $\mathrm{H}_{2} \mathrm{O}_{2}$ dosage, the removal rate of COD (in landfill leachate) reached $62.9 \%$ when the continuous feeding mode was applied, while only a $47.3 \%$ COD removal rate was obtained when $\mathrm{H}_{2} \mathrm{O}_{2}$ was added in one step. The higher COD removal rate for the continuous addition mode of $\mathrm{H}_{2} \mathrm{O}_{2}$ means that a higher $\mathrm{H}_{2} \mathrm{O}_{2}$ utilization rate occurs, which is beneficial for reduction of the $\mathrm{H}_{2} \mathrm{O}_{2}$ dosage.

In electro-Fenton-like processes, the effect of the $\mathrm{H}_{2} \mathrm{O}_{2}$ dosage on the WW treatment cost is more complicated because of the possibility of generating $\mathrm{H}_{2} \mathrm{O}_{2}$ on the surface of the cathode (see reaction equation (10)). Additionally, the activity and stability of the cathode cannot be ignored because they can have an important effect on the rate of $\mathrm{H}_{2} \mathrm{O}_{2}$ generation and the reuse performance of the cathode (which can affect the WW treatment costs). Yu et al. [208] developed a simple method using carbon black and polytetrafluoroethylene to modify graphite felt (which is used as the 
cathode). After the cathode modification more $\mathrm{H}_{2} \mathrm{O}_{2}$ was generated (a 10.7 times higher rate than before the modification) in a wider $\mathrm{pH}$ range. Meanwhile, the modified cathode showed an improved catalytic stability during the generation of $\mathrm{H}_{2} \mathrm{O}_{2}$ for 10 reuse cycles.

\subsection{Effect of parameters associated with the catalyst}

The source, preparation method, modification method, activity, and stability of the heterogeneous catalyst can affect the WW treatment cost. As mentioned in Section 4, the heterogeneous catalyst can be obtained from a wide range of sources (nature, industrial waste, artificial synthesis). In order to obtain a heterogeneous catalyst with improved catalytic activity and stability, the preparation/modification method (that can affect the WW treatment cost) is a critical step.

Taking fly ash as an example, this is a rather inexpensive source of catalyst and is usually considered to be a solid waste. Before the modification required to produce the catalyst, the rather low price of fly ash $\left(\$ 15 \operatorname{ton}^{-1}\right)$ mainly relates to the costs of transportation, chemicals, and electrical energy, etc. [209]. In addition to this industrial waste, the use of natural minerals has some similar aspects, i.e., the low price of the resource and the potential requirements for modification. The situation for artificial heterogeneous catalysts, however, is different situation because the preparation step has the most significant effect on the activity and stability of the catalyst $[105,108,172]$.

The cost for both the modification of industrial waste/natural minerals (for the catalysis purpose) and the preparation of a heterogeneous catalyst has seldom been discussed until now because the cost of the modification/preparation method differs between laboratories, as well as between the laboratory scale and the industrial scale due to issues relating to the amplification of the scale of production. 
The ability to produce a catalyst with the best catalytic activity and stability is the primary target of modification and preparation because the catalytic activity and stability can affect the WW treatment cost by influencing the catalyst loading and the reuse capacity of the catalyst, respectively. These are the main reasons for the optimization of the heterogeneous catalyst loading and the investigation into the stability of the catalyst that is found in many studies $[47,51,142]$; in other words, a lower catalyst loading and an increased number of reuse cycles are highly recommended.

For the homogeneous catalyst, prevention of precipitation/flocculation of the catalyst is critical because this effect (usually caused by an increase in $\mathrm{pH}$ ) will result in the deactivation of the catalyst, which can adversely affect the reduction of the WW treatment cost. For photo-Fenton-like processes [46, 102], more $\mathrm{HO}$ can be generated and the optimum $\mathrm{pH}$ range can be extended to the neutral range after the addition of a ligand, i.e., a lower $\mathrm{H}_{2} \mathrm{O}_{2}$ dosage is required due to the generation of more $\mathrm{HO}$, and the operation can be simplified due to the absence of the requirement for adding acid before treatment and adding alkali after the oxidization process is complete.

\subsection{Effect of parameters associated with the WW}

The nature and concentration of the WW and the required level of removal of the contaminants have been proven to have a marked influence on the WW treatment [210, 211]. In the study by Cañizares et al. [210] researchers investigated the treatment costs of synthetic wastewaters contaminated with different types of organics and that of actual wastes. As shown in Table 6 (from Cañizares et al. [210]), we can

see that the Fenton process has a lower cost when treating actual wastewater $\left(5 € / \mathrm{m}^{3}\right.$ for a $70 \%$ COD removal rate), while the conductive-diamond electrochemical 
oxidation (CDEO) process cost $11 € / \mathrm{m}^{3}$. Conversely, the cost of CDEO is competitive with that of Fenton oxidation when treating WW polluted by specific organics.

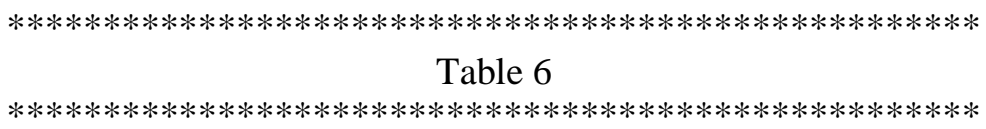

Figure 10 compares the treatment costs of Fenton oxidation and CDEO for different treatment efficiencies (and also shows the cost of oxidation by ozonation). We can see that a much higher investment is needed when a lower COD in the effluent is required. For CDEO, the cost is at least $10 € / \mathrm{m}^{3}$ when nearly complete removal of COD is required. With regard to the effect of the concentration of organics on the treatment cost, we can see from Figure 11 that the total treatment cost for a mixture of five commercial pesticides (using a combination of the photo-Fenton process with MBR as the treatment method) varies significantly with the decrease in dissolved organic carbon, i.e., the lower the pollution load, the lower the cost. Moreover, Pérez et al. [211] also reported that coupling the photo-Fenton process with MBR resulted in a $12 \%$ cost reduction when compared with that of coupling the photo-Fenton process with the traditional activated sludge process.

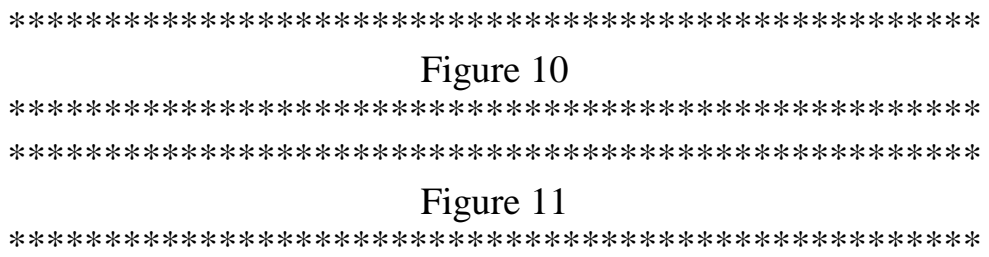

5.4 Input energy and related issues 
When a physical field/phenomenon is used to enhance Fenton-like processes, additional attention must be paid to reducing the input energy and WW treatment cost.

For the photo-Fenton-like processes, it is beneficial for researchers to note that the transmittance of the WW and the solid catalyst loading (in the heterogeneous photo-Fenton-like system) should be considered because the two parameters could have a negative effect on the WW treatment. When treating WW with poor transmittance and/or an excessive amount of solid catalyst is added, the light intensity in the WW could decrease dramatically, giving rise to a serious reduction in the WW treatment efficiency and a dramatic increase of investment on input energy. Hence, pre-treatment of the WW with low transmittance [212] and the optimization of the solid catalyst loading would be necessary.

The value of the input photo-energy can be calculated using equation (19) [211]:

$$
W=\frac{t \cdot \bar{p} \cdot A}{V_{t}}
$$

where $W$ in equation (19) is the photo-energy accumulated per unit volume $\left(\mathrm{J} \mathrm{L}^{-1}\right) ; t$ is the irradiation time $(\mathrm{s}) ; \bar{p}$ is the average incident irradiation on the radiation area $(\mathrm{w}$ $\left.\mathrm{m}^{-2}\right) ; A$ is the illuminated collector area $\left(\mathrm{m}^{2}\right) ; V_{t}$ is the total volume of the treated WW (L).

For the electrochemical processes, we should pay attention to the occurrence of passivation on the electrode surface in practical applications [213]. During WW treatment at the industrial scale, high treatment efficiency always occurs in the early stages. With the passage of time the initial pollutants and intermediates could be adsorbed on the electrode surface, giving rise to complete or partial blocking of the active sites on the electrode surface [114]; hence the surface condition of electrodes should be checked often in practical applications.

The calculation of input electric energy is shown in equation (20) [210]: 
$W=Q \cdot V$

where $W$ in equation (20) is the input electric energy per unit volume $\left(\mathrm{kWh} \mathrm{m}^{-3}\right) ; Q$ is the specific electrical charge passed $\left(\mathrm{kAh} \mathrm{m}^{-3}\right) ; V$ is the cell potential (V).

When the MW enhanced Fenton-like processes are used, the input energy and absorbed energy are always different [214]. Input energy can be obtained from equation (21):

$W_{\text {input }}=\frac{p \cdot t}{V_{t}}$

where $W_{\text {input }}$ here is the MW input energy per unit volume of treated $\mathrm{WW}\left(\mathrm{J} \mathrm{m}^{-3}\right) ; p$ is the input power $(\mathrm{W}) ; t$ is the irradiation time $(\mathrm{s}) ; V_{t}$ is the total volume of the treated $\mathrm{WW}\left(\mathrm{m}^{3}\right)$.

The calculation of the absorbed energy can be achieved using equation (22) [74]:

$W_{a b s}=\Delta T \cdot \rho \cdot C_{p}$

where $W_{a b s}$ is the energy absorbed by unit volume of the WW $\left(\mathrm{J} \mathrm{m}^{-3}\right) ; \Delta T$ is the temperature rise of the WW $(\mathrm{K}) ; \rho$ is the density of the WW $\left(\mathrm{kg} \mathrm{m}^{-3}\right) ; C_{p}$ is the heat capacity $\left(\mathrm{J} \mathrm{kg}^{-1} \mathrm{~K}^{-1}\right)$.

Before calculating the investment on energy consumption, consideration of the energy utilization rate $\left(\frac{W_{a b s}}{W_{\text {input }}} \cdot 100 \%\right)$ is recommended. Additionally, during WW treatment heat recovery should be taken into consideration because it is helpful to reduce the treatment costs for the WW (by means of saving energy).

The cost of cavitation has not always been calculated because it is widely known that when cavitation is applied alone the WW treatment technology is cost intensive [139, 215-218]. Thus, coupling between cavitation and other WW treatment technologies is encouraged to reduce the WW treatment cost. Weng et al. [139] 
applied a zero-valent iron catalysed Fenton-like process that is enhanced using US cavitation to treat dye WW. The treatment cost is shown in Table 7.

*************************************************************

Table 7

********************************************************************

It can be seen from Table 7 that the total cost was affected by power intensity, decolourization rate, and irradiation time, etc., and was in the range 2.12-3.58 USD $\mathrm{m}^{-3}$. Moreover, we can see that the investment on input energy (electricity) accounts for at least $88.2 \%$. In addition to the above study, Chakinala et al. [216] combined hydrodynamic cavitation with a zero-valent iron catalysed Fenton-like process to treat industrial WW. The study result showed that the corrosion effect (posed by hydrodynamic cavitation) on the surface of zero-valent iron resulted in the latent remediation of the WW, i.e., the organics in WW were degraded continuously without any treatment after the $15 \mathrm{~min}$ treatment by the hydrodynamic cavitation-enhanced heterogeneous Fenton-like process took place. This is rather beneficial to reduce the WW treatment cost.

\section{Proposed future research directions}

(1) Fenton-like processes have presented a broader prospect than the Fenton process due to the advantages of the Fenton-like processes (the catalyst can be recycled, the WW treatment cost is relatively low, the WW treatment efficiency can easily satisfy the discharge standards, etc.). Further and more detailed studies of the Fenton-like processes should be focused on the degradation kinetics of the organics and the mechanisms of each specific Fenton-like process for the degradation of the organics; 
this could provide a powerful theoretical support for developing novel Fenton-like processes.

(2) The catalyst plays an important role in the performance of a Fenton-like processes. The catalytic capacity of catalyst could be mainly affected by the property of leaching and the validity of active sites on the catalyst surface. Thus, the development of a kind of catalyst with low leaching rate (high stability) and high reactivity is quite important for effective organic WW treatment and reduction of WW treatment cost. In addition, the exploration of catalysts based on other kinds of metal elements (other than the Fe element) could be helpful for the development of a catalyst.

(3) Physical fields/phenomenon (including photo, electro, cavitation, and microwave) can have positive effects on the performance of Fenton-like processes during WW treatment. Although single physical field/ phenomenon-assisted Fenton-like processes have been studied widely, the combination of different physical fields/phenomenon has not attracted enough attention (only a small number of studies were conducted). Hence, in future studies, various combinations of different physical fields/phenomenon should be studied in more depth, such as the photo-electro-Fenton-like processes, MW-cavitation-Fenton processes, and MW-electro-Fenton-like processes.

\section{Conclusions}

(1) For the Fenton-like processes, although some studies still revealed that $\sim 3$ is the optimum $\mathrm{pH}$ value, other studies have illustrated that organics can be degraded effectively in the neutral (even alkaline) range. The various conclusions show the possibility of extending the optimum $\mathrm{pH}$ of Fenton-like processes to the neutral/alkaline range. 
(2) In the photo-Fenton-like processes, photochemical process is critical for the reduction of the metal catalyst in both the hetero- and homo-geneous Fenton-like processes. In the heterogeneous Fenton-like processes, photo-induced reductive dissolution of the solid catalyst is the primary mechanism for enhancing the Fenton-like processes, while in the homogeneous Fenton-like processes photochemical reduction of the metal catalyst is the main mechanism. However, the transmittance of the WW and the solid catalyst loading must be considered as a poor transmittance and/or an excessive amount of solid catalyst will result in a serious decrease of the light intensity in the WW medium.

(3) The most attractive advantage of electrochemical processes is the generation of $\mathrm{H}_{2} \mathrm{O}_{2}$ in situ and the regeneration of the metal catalyst, both via reduction on the cathode surface. The $\mathrm{H}_{2} \mathrm{O}_{2}$ generated in situ is used more efficiently than that added externally, while the regeneration of the catalyst is also beneficial to reduce the concentration of metal ion in the treated WW. However, in practical applications passivation of the electrode surface should be checked and managed. The initial pollutants and intermediates could be gradually adsorbed on the electrode surface, causing complete/partial blocking of the active sites on the electrode surface.

(4) The "hot spots" effect is the main mechanism for MW radiation to enhance the Fenton-like processes. However, the non-thermal effect of MW radiation is still in controversy as researchers have many different opinions (such as that the MW non-thermal effect plays an important role in the WW treatment, or that no MW non-thermal effect was found in a specific study). Nevertheless, many studies have shown that MW irradiation can enhance the WW treatment efficiency significantly and even relieve the passivation issue of the electrode in electrochemical processes by means of promoting the transduction of electrons to the electrode surface. 
(5) The Fenton-like processes can be enhanced significantly by the use of cavitation phenomenon via the generation of microbubbles. When cavitation microbubbles reach a critical size, they will have a violent implosive collapse, followed by localized extremely high temperature (hot spots) and high pressure. Some studies have shown the effectiveness of cavitation when combined with the Fenton-like processes.

(6) A homogeneous catalyst can be used easily when compared with a heterogeneous catalyst because the corresponding inorganic compound can be used directly as the target catalyst in a homogeneous system. Additionally, some special homogeneous catalysts were also studied (such as a Keggin-type iron-substituted heteropolytungstate anion).

(7) Many kinds of heterogeneous catalyst have been studied in recent years, including, but not limited to: natural minerals, composites by artificial synthesis, nano materials, and industrial wastes.

(8) A comprehensive exploration of novel catalysts based on other kinds of metal element (such as $\mathrm{Cu}, \mathrm{Mn}, \mathrm{Ag}$, and $\mathrm{Co}$, but not $\mathrm{Fe}$ ) still requires large numbers of studies to be completed in the future, because only a minority of the studies conducted so far have related to these metal elements.

(9) The cost evaluation of different Fenton-like processes has been conducted in some studies. However, more comprehensive evaluation is needed because it can provide powerful cost support for the development of pilot/industrial scale of Fenton-like processes.

\section{Acknowledgements}


The work was supported by State Key Laboratory of Urban Water Resource and Environment (Harbin Institute of Technology) (2015DX03) and National Science Foundation for Post-doctoral Scientists of China (2014M561356). 


\section{Reference}

[1] M.A. Oturan, J.J. Aaron, Advanced Oxidation Processes in Water/Wastewater Treatment: Principles and Applications, A Review, Crit. Rev. Env. Sci. Technol. 44 (2014) 2577-2641.

[2] J.L. Wang, L.J. Xu, Advanced Oxidation Processes for Wastewater Treatment: Formation of Hydroxyl Radical and Application, Crit. Rev. Env. Sci. Technol. 42 (2012) 251-325.

[3] J.Y. Feng, X.J. Hu, P.L. Yue, Effect of initial solution $\mathrm{pH}$ on the degradation of Orange II using clay-based Fe nanocomposites as heterogeneous photo-Fenton catalyst, Water Res. 40 (2006) 641-646.

[4] H.R. Ghatak, Advanced Oxidation Processes for the Treatment of Biorecalcitrant Organics in Wastewater, Crit. Rev. Env. Sci. Technol. 44 (2014) 1167-1219.

[5] J. Madhavan, P.S.S. Kumar, S. Anandan, F. Grieser, M. Ashokkumar, Sonophotocatalytic degradation of monocrotophos using $\mathrm{TiO}_{2}$ and $\mathrm{Fe}^{3+}$, J. Hazard. Mater. 177 (2010) 944-949.

[6] S. Sharma, M. Mukhopadhyay, Z.V.P. Murthy, Treatment of Chlorophenols from Wastewaters by Advanced Oxidation Processes, Sep. Purif. Rev. 42 (2013) 263-295.

[7] M. Kallel, C. Belaid, T. Mechichi, M. Ksibi, B. Elleuch, Removal of organic load and phenolic compounds from olive mill wastewater by Fenton oxidation with zero-valent iron, Chem. Eng. J. 150 (2009) 391-395.

[8] A.M. Amat, A. Arques, H. Beneyto, A. Garcia, M.A. Miranda, S. Segu, Ozonisation coupled with biological degradation for treatment of phenolic pollutants: A mechanistically based study, Chemosphere 53 (2003) 79-86. 
[9] E. Lee, H. Lee, Y.K. Kim, K. Sohn, K. Lee, Hydrogen peroxide interference in chemical oxygen demand during ozone based advanced oxidation of anaerobically digested livestock wastewater, Int. J. Environ. Sci. Technol. 8 (2011) 381-388.

[10] M.S. Lucas, J.A. Peres, Removal of COD from olive mill wastewater by Fenton's reagent: Kinetic study, J. Hazard. Mater. 168 (2009) 1253-1259.

[11] H.E. Hajjouji, F. Barje, E. Pinelli, J.R. Bailly, C. Richard, P. Winterton, J.C. Revel, M. Hafidi, Photochemical UV/TiO 2 treatment of olive mill wastewater (OMW), Bioresour. Technol. 99 (2009) 7264-7269.

[12] C. Karunakaran, P. Anilkumar, Semiconductor-catalyzed solar photooxidation of iodide ion, J. Mol. Catal. A: Chem. 265 (2007) 153-158.

[13] R. Molina, F. Martinez, J.A. Melero, D.H. Bremner, A.G. Chakinala, Mineralization of phenol by a heterogeneous ultrasound/Fe-SBA- $15 / \mathrm{H}_{2} \mathrm{O}_{2}$ process: Multivariate study by factorial design of experiments, Appl. Catal., B 66 (2006) 198-207.

[14] E. Neyens, J. Baeyens, A review of classic Fenton's peroxidation as an advanced oxidation technique, J. Hazard. Mater. B98 (2003) 33-50.

[15] S.P. Sun, X. Zeng, C. Li, A.T. Lemley, Enhanced heterogeneous and homogeneous Fenton-like degradation of carbamazepine by nano- $\mathrm{Fe}_{3} \mathrm{O}_{4} / \mathrm{H}_{2} \mathrm{O}_{2}$ with nitrilotriacetic acid, Chem. Eng. J. 244 (2014) 44-49.

[16] R.J. Bigda, Consider Fenton's chemistry for wastewater treatment, Chem. Eng. Prog. 91 (1995) 62-66.

[17] I. Mesquita, L.C. Matos, F. Duarte, F.J. Maldonado-Hódar, A. Mendes, L.M. Madeira, Treatment of azo dye-containing wastewater by a Fenton-like process in a continuous packed-bed reactor filled with activated carbon, J. Hazard. Mater. 237-238 (2012) 30-37. 
[18] F. Duarte, F.J. Maldonado-Hódar, L.M. Madeira, Influence of the characteristics of carbon materials on their behaviour as heterogeneous Fenton catalysts for the elimination of the azo dye Orange II from aqueous solutions, Appl. Catal., B 103 (2011) 109-115.

[19] B. Bianco, I.D. Michelis, F. Vegliò, Fenton treatment of complex industrial wastewater: optimization of process conditions by surface response method, J. Hazard. Mater. 186 (2011) 1733-1738.

[20] I. Arslan-Alaton, Degradation of a commercial textile biocide with advanced oxidation processes and ozone, J. Environ. Manage. 82 (2007) 145-154.

[21] C.T. Benatti, C.R.G. Tavares, T.A. Guedes, Optimization of Fenton's oxidation of chemical laboratory wastewaters using the response surface methodology, J. Environ. Manage. 80 (2006) 66-74.

[22] M.I. Badawy, M.Y. Ghalyb, T.A. Gad-Allah, Advanced oxidation processes for the removal of organophosphorus pesticides from wastewater, Desalin. 194 (2006) 166-175.

[23] P. Bautista, A.F. Mohedano, M.A. Gilarranz, J.A. Casas, J.J. Rodriguez, Application of Fenton oxidation to cosmetic wastewater treatment, J. Hazard. Mater. 143 (2007) 128-134.

[24] H. Kušić, A.L. Bozic, N. Koprivanac, Fenton type processes for minimization of organic content in coloured wastewaters: Part I: Processes optimization, Dyes Pigm. 74 (2007) 380-387.

[25] J.H. Ramirez, C.A. Costa, L.M. Madeira, Experimental design to optimize the degradation of the synthetic dye Orange II using Fenton's reagent, Catal. Today 107-108 (2005) 68-76. 
[26] F.J. Rivas, F.J. Beltran, O. Gimeno, P. Alvarez, Optimization of Fenton's reagent usage as a pre-treatment for fermentation brines, J. Hazard. Mater. B96 (2003) 277-290.

[27] H. Tekin, O. Bilkay, S.S. Ataberk, T.H. Balta, I.H. Ceribasi, F.D. Sanin, F.B. Dilek, U. Yetis, Use of Fenton oxidation to improve the biodegradability of apharmaceutical wastewater, J. Hazard. Mater. 136 (2006) 258-265.

[28] A.M.A. Pintor, V.J.P. Vilar, R.A.R. Boaventura, Decontamination of cork wastewaters by solar-photo-Fenton process using cork bleaching wastewater as $\mathrm{H}_{2} \mathrm{O}_{2}$ source, Sol. Energy 85 (2011) 579-587.

[29] E.C. Catalkaya, F. Kargi, Color, TOC and AOX removals from pulp mill effluent by advanced oxidation processes: a comparative study, J. Hazard. Mater. 139 (2007) 244-253.

[30] A. Lopez, G. Mascolo, A. Detomaso, G. Lovecchio, G. Villani, Temperature activated degradation (mineralization) of 4-chloro-3-methyl phenol by Fenton's reagent, Chemosphere 59 (2005) 397-403.

[31] S.H. Yuan, N. Gou, A.N. Alshawabkeh, A.Z. Gu, Efficient degradation of contaminants of emerging concerns by a new electro-Fenton process with Ti/MMO cathode, Chemosphere 93 (2013) 2796-2804.

[32] S. Sabhi, J. Kiwi, Degradation of 2,4-dichlorophenol by immobilized iron catalysts, Water Res. 35 (2001) 1994-2002.

[33] X.Q. Fan, H.Y. Hao, Y.C. Wang, F. Chen, J.L. Zhang, Fenton-like degradation of nalidixic acid with $\mathrm{Fe}^{3+} / \mathrm{H}_{2} \mathrm{O}_{2}$, Environ. Sci. Pollut. Res. 20 (2013) 36490-3656.

[34] J. Maekawa, K. Mae, H. Nakagawa, Fenton-Cu ${ }^{2+}$ system for phenol mineralization, J. Environ. Chem. Eng. 2 (2014) 1275-1280. 
[35] H.Y. Xu, W.C. Liu, S.Y. Qi, Y. Li, Y. Zhao, J.W. Li, Kinetics and optimization of the decoloration of dyeing wastewater by a schorl-catalyzed Fenton-like reaction, J. Serb. Chem. Soc. 79 (2014) 361-377.

[36] A. Shinya, L. Bergwall, Pyrite oxidation: Review and prevention practices, J. Vertebr. Paleontol. 27 (2007) 145A-145A.

[37] A. Babuponnusami, K. Muthukumar, Removal of phenol by heterogeneous photo electro Fenton-like process using nano-zero valent iron, Sep. Purif. Technol. 98 (2012) 130-135.

[38] M. Dehghani, E. Shahsavani, M. Farzadkia, M.R. Samaei, Optimizing photo-Fenton like process for the removal of diesel fuel from the aqueous phase, J. Env. Health Sci. Eng. 12 (2014) 1-17.

[39] B.L. Fei, Q.L. Yan, J.H. Wang, Q.B. Liu, J.Y. Long, Y.G. Li, K.Z. Shao, Z.M. Su, W.Y. Sun, Green Oxidative Degradation of Methyl Orange with Copper(II) Schiff Base Complexes as Photo-Fenton-Like Catalysts, Z. Anorg. Allg. Chem. 640 (2014) 2035-2040.

[40] S.R. Pouran, A.R.A. Aziz, W.M.A.W. Daud, Review on the main advances in photo-Fenton oxidation system for recalcitrant wastewaters, J. Ind. Eng. Chem. 21 (2015) 53-69.

[41] E. Alfaya, O. Iglesias, M. Pazos, M.A. Sanroman, Environmental application of an industrial waste as catalyst for the electro-Fenton-like treatment of organic pollutants, RSC Adv. 5 (2015) 14416-14424.

[42] B. Balcl, M.A. Oturan, N. Oturan, L. Sires, Decontamination of Aqueous Glyphosate, (Aminomethyl). phosphonic Acid, and Glufosinate Solutions by Electro-Fenton-like Process with $\mathrm{Mn}^{2+}$ as the Catalyst, J. Agric. Food. Chem. 57 (2009) 4888-4894. 
[43] E. Brillas, I. Sires, M.A. Oturan, Electro-Fenton Process and Related Electrochemical Technologies Based on Fenton's Reaction Chemistry, Chem. Rev. 109 (2009) 6570-6631.

[44] R. Chand, N.H. Ince, D.H. Bremner, Phenol degradation using 20, 300 and 520 $\mathrm{kHz}$ ultrasonic reactors with hydrogen peroxide or ozone and zero valent metals, Sep. Purif. Technol. 67 (2009) 103-109.

[45] G.M.S. Elshafei, F.Z. Yehia, O.I.H. Dimitry, A.M. Badawi, G. Eshaq, Ultrasonic assisted-Fenton-like degradation of nitrobenzene at neutral $\mathrm{pH}$ using nanosized oxides of $\mathrm{Fe}$ and $\mathrm{Cu}$, Ultrason. Sonochem. 21 (2014) 1358-1365.

[46] C.K. Wang, Y.H. Shih, Degradation and detoxification of diazinon by sono-Fenton and sono-Fenton-like processes, Sep. Purif. Technol. 140 (2015) 6-12.

[47] A.Y. Atta, B.Y. Jibril, T.K. Al-Waheibi, Y.M. Al-Waheibi, Microwaveenhanced catalytic degradation of 2-nitrophenol on alumina-supported copper oxides, Catal. Commun. 26 (2012) 112-116.

[48] R. Carta, F. Desogus, The enhancing effect of low power microwaves on phenol oxidation by the Fenton process, J. Environ. Chem. Eng. 1 (2013) 1292-1300.

[49] X.J. Yang, P.F. Tian, X.M. Zhang, X. Yu, T. Wu, J. Xu, Y.F. Han, The generation of hydroxyl radicals by hydrogen peroxide decomposition on FeOCl/SBA-15 catalysts for phenol degradation, AlChE J. 61 (2014) 166-176.

[50] C. Zhang, M.H. Zhou, G.B. Ren, X.M. Yu, L. Ma, J. Yang, F.K. Yu, Heterogeneous electro-Fenton using modifiedironecarbon as catalyst for 2,4-dichlorophenol degradation: Influence factors, mechanism and degradation pathway, Water Res. 70 (2015) 414-424. 
[51] C.W. Yang, D. Wang, Q. Tang, The synthesis of NdFeB magnetic activated carbon and its application in degradation of azo dye methyl orange by Fenton-like process, J. Taiwan Inst. Chem. Eng. 45 (2014) 2584-2589.

[52] M. Catala, N. Dominguez-Morueco, A. Migens, R. Molina, F. Martinez, Y. Valcarcel, N. Mastroianni, M. Lopez de Alda, D. Barcelo, Y. Segura, Elimination of drugs of abuse and their toxicity from natural waters by photo-Fenton treatment, Sci. Total Environ. 520 (2015) 198-205.

[53] Z.P. Wang, Y.Z. Guo, Z.Z. Liu, X.N. Feng, Y.Q. Chen, T. Tao, Catechin as a new improving agent for a photo-Fenton-like system at near-neutral $\mathrm{pH}$ for the removal of Inderal, Photochem. Photobiol. Sci. 14 (2015) 473-480.

[54] Y. Yang, P. Wang, S. Shi, Y. Liu, Microwave enhanced Fenton-like process for the treatment of high concentration pharmaceutical wastewater, J. Hazard. Mater. 168 (2009) 238-245.

[55] P. Yan, L.B. Gao, W.T. Li, Microwave-enhanced Fenton-like system, $\mathrm{Fe}_{3} \mathrm{O}_{4} / \mathrm{H}_{2} \mathrm{O}_{2}$, for Rhodamine B wastewater degradation, Appl. Mech. Mater. 448-453 (2014) 834-837.

[56] L. Yu, C.P. Wang, X.H. Ren, H.W. Sun, Catalytic oxidative degradation of bisphenol A using an ultrasonic-assisted tourmaline-based system: Influence factors and mechanism study, Chem. Eng. J. 252 (2014) 346-354.

[57] P. Bautista, A.F. Mohedano, J.A. Casas, J.A. Zazo, J.J. Rodriguez, An overview of the application of Fenton oxidation to industrial wastewaters treatment, J. Chem. Technol. Biotechnol. 83 (2008) 1323-1338.

[58] G. Pliego, J.A. Zazo, P. Garcia-Munoz, M. Munoz, J.A. Casas, J.J. Rodriguez, Trends in the intensification of the Fenton process for wastewater treatment-An overview. Crit. Rev. Env. Sci. Technol. 45 (2015) 2611-2692. 
[59] T. Zhou, T.T. Lim, X.H. Wu, Sonophotolytic degradation of azo dye reactive black 5 in an ultrasound/UV/ferric system and the roles of different organic ligands, Water Res. 45 (2011) 2915-2924.

[60] Y.H. Huang, C.C. Su, Y.P. Yang, M.C. Lu, Degradation of Aniline Catalyzed by Heterogeneous Fenton-like Reaction Using Iron Oxide/SiO ${ }_{2}$, Environ. Prog. Sustainable Energy 32 (2013) 187-192.

[61] Y. Feng, D.L. Wu, D. Duan, L.M. Ma, Fenton-like Oxidation of refractory chemical wastewater using pyrite, Adv. Mater. Res. 518-523 (2012) 2518-2525.

[62] S. Hashemian, Fenton-like Oxidation of Malachite Green Solutions: Kinetic and Thermodynamic Study, J. Chem. (2013).

[63] G. Hodaifa, J.M. Ochando-Pulido, S. Rodriguez-Vives, A. Martinez-Ferez, Optimization of continuous reactor at pilot scale for olive-oil mill wastewater treatment by Fenton-like process, Chem. Eng. J. 220 (2013) 117-124.

[64] A.O. Ifelebuegu, C.P. Ezenwa, Removal of Endocrine Disrupting Chemicals in Wastewater Treatment by Fenton-Like Oxidation, Water Air Soil Pollut. 217 (2011) 213-220.

[65] L.M. Nieto, G. Hodaifa, S. Rodríguez, J.A. Giménez, J. Ochando, Degradation of organic matter in olive-oil mill wastewater through homogeneous Fenton-like reaction, Chem. Eng. J. 173 (2011) 503-510.

[66] J.L. Tambosi, M.D. Domenico, W.N. Schirmer, H.J. Jose, R.D. FPM Moreira, Treatment of paper and pulp wastewater and removal of odorous compounds by a Fenton-like process at the pilot scale, J. Chem. Technol. Biotechnol. 81 (2006) $1426-1432$. 
[67] S.H. You, L.L. Ma, Q.L. Xie, K. Li, Advanced treatment of molasses alcohol wastewater using Fenton-like reagent. 2011 Second Int. Conf. Mech. Autom. Control Eng. (2011) 1911-1913.

[68] C.C. Jiang, S.Y. Pang, F. Ouyang, J. Ma, J. Jiang, A new insight into Fenton and Fenton-like processes for water treatment, J. Hazard. Mater. 174 (2010) 813-817.

[69] J.H. Ramirez, F.J. Maldonado-Hodar, A.F. Perez-Cadenas, C. Moreno-Castilla, C.A. Costa, L.M. Madeira, Azo-dye Orange II degradation by heterogeneous Fenton-like reaction using carbon-Fe catalysts, Appl. Catal., B 75 (2007) 312-323.

[70] J.J. Wu, M. Muruganandham, J.S. Yang, S.S. Lin, Oxidation of DMSO on goethite catalyst in the presence of $\mathrm{H}_{2} \mathrm{O}_{2}$ at neutral $\mathrm{pH}$, Catal. Commun. 7 (2006) 901-906.

[71] X.F. Xue, K. Hanna, M. Abdelmoula, N.S. Deng, Adsorption and oxidation of PCP on the surface of magnetite: kinetic experiments and spectroscopic investigations, Appl. Catal., B 89 (2009) 432-440.

[72] X.F. Xue, K. Hanna, N.S. Deng, Fenton-like oxidation of Rhodamine B in the presence of two types of iron (II, III) oxide, J. Hazard. Mater. 166 (2009) 407-414.

[73] L.M. Pastrana-Martinez, N. Pereira, R. Lima, J.L. Faria, H.T. Gomes, A.M.T. Silva, Degradation of diphenhydramine by photo-Fenton using magnetically recoverable iron oxide nanoparticles as catalyst, Chem. Eng. J. 261 (2015) 45-52.

[74] N.N. Wang, T. Zheng, J.P. Jiang, W.S. Lung, X.J. Miao, P. Wang, Pilot-scale treatment of p-Nitrophenol wastewater by Microwave-enhanced Fenton oxidation process: Effects of system parameters and kinetics study, Chem. Eng. J. 239 (2014) 351-359. 
[75] A.L. Zhang, N.N. Wang, J.T. Zhou, P. Jiang, G.F. Liu, Heterogeneous Fenton-like catalytic removal of p-nitrophenol in water using acid-activated fly ash, J. Hazard. Mater. 201-202 (2012) 68-73.

[76] H. Zhang, X.G. Wu, X.W. Li, Oxidation and coagulation removal of COD from landfill leachate by Fered-Fenton process, Chem. Eng. J. 210 (2012) 188-194.

[77] P.P. Gan, S.F.Y. Li, Efficient removal of Rhodamine B using a rice hull-based silica supported iron catalyst by Fenton-like process, Chem. Eng. J. 229 (2013) 351-363.

[78] R. Idel-aouad, M. Valente, A. Yaacoubi, B. Tanouti, M. López-Mesas, Rapid decolourization and mineralization of the azo dye C.I. Acid Red 14 by heterogeneous Fenton reaction, J. Hazard. Mater. 186 (2011) 745-750.

[79] J.A. Zazo, G. Pliego, S. Blasco, J.A. Casas, J.J. Rodriguez, Intensification of the Fenton process by increasing the temperature, Ind. Eng. Chem. Res. 50 (2011) 866-870.

[80] H.Y. Xu, M. Prasad, Y. Liu, Schorl: A novel catalyst in mineral-catalyzed Fenton-like system for dyeing wastewater discoloration, J. Hazard. Mater. 165 (2009) 1186-1192.

[81] M. Munoz, G. Pliego, Z.M.D. Pedro, J.A. Casas, J.J. Rodriguez, Application of intensified Fenton oxidation to the treatment of sawmill Wastewater, Chemosphere 109 (2014) 34-41.

[82] H.Y. Xu, P. Murari, X.L. He, L.W. Shan, S.Y. Qi, Discoloration of Rhodamine B dyeing wastewater by schorl-catalyzed Fenton-like reaction, Sci. China Ser. E: Technol. Sci. 52 (2009) 3054-3060. 
[83] H.Y. Xu, S.Y. Qi, Y. Li, Y. Zhao, Heterogeneous Fenton-like discoloration of Rhodamine B using natural schorl as catalyst: optimization by response surface methodology, Environ. Sci. Pollut. Res. 20 (2013) 5764-5772.

[84] Y.Y. Zhang, C. He, V.K. Sharma, X.Z. Li, S.H. Tian, Y. Xiong, A coupling process of membrane separation and heterogeneous Fenton-like catalytic oxidation for treatment of acid orange II-containing wastewater, Sep. Purif. Technol. 80 (2011) $45-51$.

[85] A.R. Prazeres, F. Carvalho, J. Rivas, Fenton-like application to pretreated cheese whey wastewater, J. Environ. Manage. 129 (2013) 199-205.

[86] J. Zhao, J.J. Yang, J. Ma, Mn(II).-enhanced oxidation of benzoic acid by $\mathrm{Fe}(\mathrm{III}) / \mathrm{H}_{2} \mathrm{O}_{2}$ system, Chem. Eng. J. 239 (2014) 171-177.

[87] H. Iboukhoulef, A. Amrane, H. Kadi, Removal of phenolic compounds from olive mill wastewater by a Fenton-like system $\mathrm{H}_{2} \mathrm{O}_{2} / \mathrm{Cu}(\mathrm{II})$-thermodynamic and kinetic modelling, Desalin. Water Treat. 1-6 (2014).

[88] Burrows, H.D., L, M.C., Santaballa, J.A., and Steenken, S. Reaction pathways and mechanisms of photodegradation of pesticides, J. Photochem. Photobiol., B 67 (2002) 71-108.

[89] S.O. Pehkonen, R.L. Siefert, M.R. Hoffmann, Photo-reduction of iron oxyhydroxides and the photo-oxidation of halogenated acetic acids, Environ. Sci. Technol. 29 (1995) 1215-1222.

[90] C. Pulgarin, J. Kiwi, Iron oxide-mediated degradation, photodegradation, and biodegradation of aminophenols, Langmuir 11 (1995) 519-526.

[91] D. T. Waite, F.M. Morel, Photoreductive dissolution of colloidal iron oxides in nature waters, Environ. Sci. Technol. 18 (1984) 860-868. 
[92] S. Kalal, N.P.S. Chauhan, N. Ameta, R. Ameta, S. Kumar, P.B. Punjabi, Role of copper pyrovanadate as heterogeneous photo-Fenton like catalyst for the degradation of neutral red and azure-B: An eco-friendly approach, Korean J. Chem. Eng. 31 (2014) 2183-2191.

[93] F.L.Y. Lam, A.C.K. Yip, X.J. Hu, Copper/MCM-41 as a highly stable and $\mathrm{pH}$-insensitive heterogeneous photo-Fenton-like catalytic material for the abatement of organic wastewater, Ind. Eng. Chem. Res. 46 (2007) 3328-3333.

[94] A. Babuponnusami, K. Muthukumar, A review on Fenton and improvements to the Fenton process for wastewater treatment, J. Environ. Chem. Eng. 2 (2014) $557-572$.

[95] H.J. Lee, H.S. Lee, C.H. Lee, Degradation of diclofenac and carbamazepine by the copper(II).-catalyzed dark and photo-assisted Fenton-like systems, Chem. Eng. J. 245 (2014) 258-264.

[96] Pignatello, J.J., E. Oliveros, A. MacKay, Advanced Oxidation Processes for Organic Contaminant Destruction Based on the Fenton Reaction and Related Chemicstry, Crit. Rev. Env. Sci. Technol. 36 (2006) 1-84.

[97] S. Fassi, K. Djebbar, I. Bousnoubra, H. Chenini, T. Sehili, Oxidation of bromocresol green by different advanced oxidation processes: Fenton, Fenton-like, photo-Fenton, photo-Fenton-like and solar light. Comparative study, Desalin. Water Treat. 52 (2014) 4982-4989.

[98] A. Jain, D. Vaya, V.K. Sharma, S.C. Ameta, Photo-Fenton degradation of phenol red catalyzed by inorganic additives: A technique for wastewater treatment, Kinet. Catal. 52 (2011) 40-47. 
[99] D. Kim, J.K. Chen, T.F. Yen, Naval derusting wastewater containing high concentration of iron, treated in UV photo-Fenton-like oxidation, J. Environ. Sci. 22 (2010) 991-997.

[100] T. Olmez-Hanci, I. Arslan-Alaton, O. Gelegen, Photo-Fenton-like treatment of K-acid: assessment of treat ability, toxicity and oxidation products, Water Sci. Technol. 70 (2014) 1056-1064.

[101] K. Hanna, D. Vione, Activation of Persulfate by Irradiated Magnetite: Implications for the Degradation of Phenol under Heterogeneous Photo-Fenton-like Conditions, Environ. Sci. Technol. 49 (2015) 1043-1050.

[102] M. Masarwa, H. Cohen, D. Meyerstein, D.L. Hickman, A. Bakac, J.H. Espenson, Reactions of Low-Valent Transition-Metal Complexes with Hydrogen Peroxide. Are They "Fenton-like" or Not? 1. The Case of $\mathrm{Cu}^{+}{ }_{\mathrm{aq}}$ and $\mathrm{Cr}^{2+}{ }_{\mathrm{aq}}, \mathrm{J}$. Am. Chem. Soc. 110 (1988) 4293-4297.

[103] J. Gomis, R.F. Vercher, A.M. Amat, D.O. Mártire, M.C. González, A.B. Prevot, E. Montoneri, A. Arques, L. Carlos, Application of soluble bio-organic substances (SBO) as photocatalysts for wastewater treatment: Sensitizing effect and photo-Fenton-like process, Catal. Today 209 (2013) 176-180.

[104] F. Mendez-Arriaga, R. Almanza, Water remediation by $\mathrm{UV}-\mathrm{vis} / \mathrm{H}_{2} \mathrm{O}_{2}$ process, photo-Fenton-like oxidation, and zeolite ZSM5, Desalin. Water Treat. 52 (2014) $5822-5832$.

[105] M. Sheydaei, S. Aber, A. Khataee, Preparation of a novel $\gamma-F e O O H-G A C$ nano composite for decolorization of textile wastewater by photo Fenton-like process in a continuous reactor, J. Mol. Catal. A: Chem. 392 (2014) 229-234. 
[106] L.Q. Guo, F. Chen, X.Q. Fan, W.D. Cai, J.L. Zhang, S-doped $\alpha-\mathrm{Fe}_{2} \mathrm{O}_{3}$ as a highly active heterogeneous Fenton-like catalyst towards the degradation of acid orange 7 and phenol, Appl. Catal., B 96 (2010) 162-168.

[107] B. Li, Y.C. Dong, C. Zou, Y.M. Xu, Iron(III)-Alginate Fiber complex as a highly effective and stable heterogeneous Fenton photocatalyst for mineralization of organic dye, Ind. Eng. Chem. Res. 53 (2014) 4199-4206.

[108] Y.Z. Chen, N. Li, Y. Zhang, L.D. Zhang, Novel low-cost Fenton-like layered Fe-titanate catalyst: Preparation, characterization and application for degradation of organic colorants, J. Colloid Interface Sci. 422 (2014) 9-15.

[109] Z.P. Xing, D.Z. Sun, X.J. Yu, Treatment of antibiotic fermentation wastewater using the combined polyferric sulfate coagulation with Fenton-Like oxidation, Environ. Prog. Sustainable Energy 29 (2010) 42-51.

[110] I. Sires, E. Brillas, M.A. Oturan, M.A. Rodrigo, M. Panizza, Electrochemical advanced oxidation processes: today and tomorrow. A Review, Environ. Sci. Pollut. Res. 21 (2014) 8336-8367.

[111] E. Brillas, Electro-Fenton, UVA Photoelectro-Fenton and Solar Photoelectro-Fenton Treatment of Organics in Waters Using a Boron-Doped Diaond Anode: A Review, J. Mex. Chem. Soc. 58 (2014) 239-255.

[112] X.M. Yu, M.H. Zhou, Y.S. Hu, K.G. Serrano, F.K. Yu, Recent updates on electrochemical degradation of bio-refractory organic pollants using BDD anode: a mini review, Environ. Sci Pollut Res 21 (2014) 8417-8431.

[113] P.V. Nidheesh, R. Gandhimathi, Electro Fenton Oxidation for the removal of Rhodamine B from aqueous solution in a bubble column reactor under continuous mode, Desalin. Water Treat. 55 (2015) 263-271. 
[114] Y.J. Wang, H.Y. Zhao, J.X. Gao, G.H. Zhao, Y.G. Zhang, Y.L. Zhang, Rapid Mineralization of Azo-Dye Wastewater by Microwave Synergistic Electro-Fenton Oxidation Process, J. Phys. Chem. C 116 (2012) 7457-7463.

[115] S. Liu, Y. Gu, S.L. Wang, Y. Zhang, Y.F. Fang, D.M. Johnson, Y.P. Huang, Degradation of organic pollutants by a $\mathrm{Co}_{3} \mathrm{O}_{4}$-graphite composite electrode in an electro-Fenton-like system, Chin. Sci. Bull. 58 (2013) 2340-2346.

[116] U. Kurt, O. Apaydin, M.T. Gonullu, Reduction of COD in wastewater from an organized tannery industrial region by Electro-Fenton process, J. Hazard. Mater. 143 (2007) 33-40.

[117] M. Panizza, G. Cerisola, Electro-Fenton degradation of synthetic dyes, Water Res. 43 (2009) 339-344.

[118] E. Bocos, C. Fernández-Costas, M. Pazos, M.Á. Sanromán, Removal of PAHs and pesticides from polluted soils by enhanced electro kinetic-Fenton treatment, Chemosphere 125 (2015) 168-174.

[119] W.P. Ting, M.C. Lu, Y.H. Huang, Kinetics of 2,6-dimethylaniline degradation by electro-Fenton process, J. Hazard. Mater. 161 (2009) 1484-1490.

[120] M.A. Oturan, J. Peiroten, P. Chartrin, A.J. Acher, Complete destruction of p-nitrophenol in aqueous medium by electro-Fenton method, Environ. Sci. Technol. 34 (2000) 3474-3479.

[121] P.V. Nidheesh, R. Gandhimathi, Comparative Removal of Rhodamine B from Aqueous Solution by Electro-Fenton and Electro-Fenton-like Processes, Clean-Soil Air Water 42 (2014) 779-784.

[122] P.V. Nidheesh, R. Gandhimathi, Electrolytic removal of Rhodamine B from aqueous solution by peroxicoagulation process, Environ Sci Pollut Res 21 (2014) 8585-8594. 
[123] P.V. Nidheesh, R. Gandhimathi, Effect of solution $\mathrm{pH}$ on the performance of three electrolytic advanced oxidation processes for the treatment of textile wastewater and sludge characteristics, RSC Adv. 4 (2014) 27946-27954.

[124] N. Oturan, M.H. Zhou, M.A. Oturan, Metomyl degradation by electro-Fenton and electro-Fenton-like processes: A kinetics study of the effect of the nature and concentration of some transition metal ions as catalyst, J. Phys. Chem. A 114 (2010) 10605-10611.

[125] W.P. Ting, M.C. Lu, Y.H. Huang, The reactor design and comparison of Fenton, electro-Fenton and photoelectron-Fenton processes for mineralization of benzene sulfonic acid (BSA), J. Hazard. Mater. 156 (2008) 421-427.

[126] D. Venu, R. Gandhimathi, P.V. Nidheesh, S.T. Ramesh, Treatment of stabilized landfill leachate using peroxicoagulation process, Sep. Purif. Technol. 129 (2014) 64-70.

[127] C.T. Wang, Y.J. Hua, Y.X. Tong, A novel Electro-Fenton-Like system using $\mathrm{PW}_{11} \mathrm{O}_{39} \mathrm{Fe}(\mathrm{III}) .\left(\mathrm{H}_{2} \mathrm{O}\right){ }^{4-}$ as an electrocatalyst for wastewater treatment, Electrochim. Acta 55 (2010) 6755-6760.

[128] H. Zhang, C.Z. Fei, D.B. Zhang, F. Tang, Degradation of 4-nitrophenol in aqueous medium by electro-Fenton method, J. Hazard. Mater. 145 (2007) 227-232.

[129] P.V. Nidheesh, R. Gandhimathi, N.S. Sanjini, $\mathrm{NaHCO}_{3}$ enhanced Rhodamine B removal from aqueous solution by graphite-graphite electro Fenton system, Sep. Purif. Technol. 132 (2014) 568-576.

[130] P.V. Nidheesh, R. Gandhimathi, Removal of Rhodamine B from aqueous solution using graphite-graphite electro-Fenton system, Desalin. Water Treat. 52 (2014) 1872-1877. 
[131] P.V. Nidheesh, R. Gandhimathi, S. Velmathi, N.S. Sanjini, Magnetite as a heterogeneous electro Fenton catalyst for the removal of Rhodamine B from aqueous solution, RSC Adv. 4 (2014) 5698-5708.

[132] W.Y. He, X.N. Yan, H.Z. Ma, J. Yu, J. Wang, X.L. Huang, Degradation of methyl orange by electro-Fenton-like process in the presence of chloride ion, Desalin. Water Treat. 51 (2013) 6562-6571.

[133] M.V. Bagal, P.R. Gogate, Degradation of 2,4-dinitrophenol using a combination of hydrodynamic cavitation, chemical and advanced oxidation processes, Ultrason. Sonochem. 20 (2013) 1226-1235.

[134] P.N. Patil, S.D. Bote, P.R. Gogate, Degradation of imidacloprid using combined advanced oxidation processes based on hydrodynamic cavitation, Ultrason. Sonochem. 21 (2014) 1770-1777.

[135] Y.L. Song, J.T. Li, Degradation of C.I. Direct Black 168 from aqueous solution by fly ash/ $\mathrm{H}_{2} \mathrm{O}_{2}$ combining ultrasound, Ultrason. Sonochem. 16 (2009) 440-444.

[136] K.S. Suslick, Sonochemistry, Sci. 247 (1990) 1439-1445.

[137] C.D. Wu, Z.L. Zhang, Y. Wu, L. Wang, L.J. Chen, Effects of operating parameters and additives on degradation of phenol in water by the combination of $\mathrm{H}_{2} \mathrm{O}_{2}$ and hydrodynamic cavitation, Desalin. Water Treat. 53 (2015) 462-468

[138] M.A. Beckett, I. Hua, Elucidation of the 1,4-Dioxane decomposition pathway at discrete ultrasonic frequencies, Environ. Sci. Technol. 34 (2000) 3944-3953.

[139] C.H. Weng, Y.T. Lin, C.K. Chang, N. Liu, Decolourization of direct blue 15 by Fenton/ultrasonic process using a zero-valent iron aggregate catalyst, Ultrason. Sonochem. 20 (2013) 970-977. 
[140] J. Liang, S. Komarov, N. Hayashi, E. Kasai, Recent trends in the decomposition of chlorinated aromatic hydrocarbons by ultrasound irradiation and Fenton's reagent, J. Mater. Cycles Waste Manage. 9 (2007) 47-55.

[141] T. Zhou, X.H. Wu, J. Mao, Y.R. Zhang, T.T. Lim, Rapid degradation of sulfonamides in a novel heterogeneous sonophotochemical magnetite-catalyzed Fenton-like (US/UV/Fe ${ }_{3} \mathrm{O}_{4} /$ oxalate) system, Appl. Catal., B 160-161 (2014) 325-334. [142] R.X. Huang, Z.Q. Fang, X.B. Fang, E.P. Tsang, Ultrasonic Fenton-like catalytic degradation of bisphenol A by ferroferricoxide $\left(\mathrm{Fe}_{3} \mathrm{O}_{4}\right)$. nanoparticles prepared from steel pickling waste liquor, J. Colloid Interface Sci. 436 (2014) 258-266.

[143] H. Zhang, H. Fu, D.B. Zhang Degradation of C.I. Acid Orange 7 by ultrasound enhanced heterogeneous Fenton-like process, J. Hazard. Mater. 172 (2009) 654-660.

[144] M. Muruganandham, J.S. Yang, J.J. Wu, Effect of ultrasonic irradiation on the catalytic activity and stability of goethite catalyst in the presence of $\mathrm{H}_{2} \mathrm{O}_{2}$ at acidic medium, Ind. Eng. Chem. Res. 46 (2007) 691-698.

[145] T. Zhou, T.T. Lim, X.H. Lu, Y.Z. Li, F.S. Wong, Simultaneous degradation of 4-CP and EDTA in a heterogeneous Ultrasound/Fenton like system at ambient circumstance, Sep. Purif. Technol. 68 (2009) 367-374.

[146] T. Zhou, X.H. Lu, J. Wang, F.S. Wong, Y.Z. Li, Rapid decolorization and mineralization of simulated textile wastewater in a heterogeneous Fenton like system with/without external energy, J. Hazard. Mater. 165 (2009) 193-199.

[147] H.M. Zhou, Y.Y. Shen, P. Lv, J.J. Wang, P. Li, Degradation pathway and kinetics of 1-alkyl-3-methylimidazolium bromides oxidation in an ultrasonic nanoscale zero-valent iron/hydrogen peroxide system, J. Hazard. Mater. 284 (2015) 241-252. 
[148] J.T. Li, B. Bai, Y.L. Song, Degradation of Acid Orange 3 in aqueous solution by combination of Fly ash/ $\mathrm{H}_{2} \mathrm{O}_{2}$ and ultrasound irradiation, Indian J. Chem. Technol. 17 (2010) 198-203.

[149] H. Liu, M.Y. Liang, C.S. Liu, Y.X. Gao, J.M. Zhou, Catalytic degradation of phenol in sonolysis by coal ash and $\mathrm{H}_{2} \mathrm{O}_{2} / \mathrm{O}_{3}$, Chem. Eng. J. 153 (2009) 131-137.

[150] B. Neppolian, J. Park, H. Choi, Effect of Fenton-like oxidation on enhanced oxidative degradation of para-chlorobenzoic acid by ultrasonic irradiation, Ultrason. Sonochem. 11 (2004) 273-279.

[151] P. Wang, T. Zheng, G.S. Zhang, Environmental microwave chemistry technology, Science Press, Beijing, 2014.

[152] H. Hidaka, A. Saitou, H. Honjou, K. Hosoda, M. Moriya, N. Serpone, Microwave assisted dechlorination of polychlorobenzenes by hypophosphite anions in aqueous alkaline media in the presence of Pd-loaded active carbon, J. Hazard. Mater. 148 (2007) 22-28.

[153] J.A. Menendez, M. Inguanzo, J.J. Pis, Microwave induced pyrolysis of sewage sludge, Water Res. 36 (2002) 3261-3264.

[154] D.M. Gu, Y.Y. Chu, Z.B. Wang, Z.Z. Jiang, G.P. Yin, Y. Liu, Methanol oxidation on $\mathrm{Pt} / \mathrm{CeO}_{2}-\mathrm{C}$ electrocatalyst prepared by microwave-assisted ethylene glycol process, Appl. Catal., B 102 (2011) 9-18.

[155] N. Li, P. Wang, C. Zuo, H.L. Cao, Q.S. Liu, Microwave-Enhanced Fenton Process for DMSO-Containing wastewater, Environ. Eng. Sci. 27 (2010) 271-280.

[156] I. Milosevic, H. Jouni, C. David, F. Warmont, D. Bonnin, L. Motte, Facile microwave process in water for the fabrication of magnetic nanorods, J. Phys. Chem. C 115 (2011) 18999-19004. 
[157] Z.H. Ai, P. Yang, X.H. Lu, Degradation of 4-Chlorophenol by microwave irradiation enhanced advanced oxidation processes, Chemosphere 60 (2005) 824-827. [158] P. Klán, M. Hájek, V. Církva, The electrodeless discharge lamp: a prospective tool for photochemistry Part 3. The microwave photochemistry reactor, J. Photochem. Photobiol., A 140 (2001) 185-189.

[159] F. Parolin, U.M. Nascimento, E.B. Azevedo, Microwave-enhanced-UV/ $/ \mathrm{H}_{2} \mathrm{O}_{2}$ degradation of an azo dye (tartrazine): optimization, colour removal, mineralization and ecotoxicity, Environ. Technol. 34 (2013) 1247-1253.

[160] G. Cheng, J. Lin, J. Lu, X. Zhao, Z.Q. Cai, J. Fu, Advanced Treatment of Pesticide-Containing Wastewater Using Fenton Reagent Enhanced by Microwave Electrodeless Ultraviolet, BioMed Res. Int. (2015).

[161] W.C. Liao, T. Zheng, P. Wang, S.S. Tu, W.Q. Pan, Microwave-Assisted Photocatalytic Degradation of Dimethyl Phthalate Over a Novel $\mathrm{ZrO}_{\mathrm{x}}$ Catalyst, Environ. Eng. Sci. 27 (2010) 1001-1007.

[162] W.C. Liao, T. Zheng, P. Wang, S.S. Tu, W.Q Pan, Efficient microwave-assisted photocatalytic degradation of endocrine disruptor dimethyl phthalate over composite catalyst $\mathrm{ZrO}_{\mathrm{x}} / \mathrm{ZnO}$, J. Environ. Sci. 22 (2010) 1800-1806.

[163] W.Q. Pan, G.S. Zhang, T. Zheng, P. Wang, Degradation of p-nitrophenol using $\mathrm{CuO} / \mathrm{Al}_{2} \mathrm{O}_{3}$ as a Fenton-like catalyst under microwave irradiation, RSC Adv. 5 (2015) 27043-27051.

[164] X.D. Qi, Z.H. Li, Efficiency optimization of organic pollutant removal in pharmaceutical wastewater by microwave-assisted Fenton-like technology, Appl. Mech. Mater. 694 (2014) 406-410. 
[165] H. Iboukhoulef, A. Amrane, H. Kadi, Microwave-enhanced Fenton-like system, $\mathrm{Cu}(\mathrm{II}) . / \mathrm{H}_{2} \mathrm{O}_{2}$, for olive mill wastewater treatment, Environ. Technol. 34 (2013) 853-860.

[166] M. Hartmann, S. Kullmann, H. Keller, Wastewater treatment with heterogeneous Fenton-type catalysts based on porous materials, J. Mater. Chem. 20 (2010) 9002-9017.

[167] R. Andreozzi, V. Caprio, R. Marotta, Oxidation of 3,4-dihydroxybenzoic acid by means of hydrogen peroxide in aqueous goethite slurry, Water Res. 36 (2002) 2761-2768.

[168] R. Andreozzi, A. D'Apuzzo, R. Marotta, Oxidation of aromatic substrates in water/goethite slurry by means of hydrogen peroxide, Water Res. 36 (2002) 4691-4698.

[169] H.H. Huang, M.C. Lu, J.N. Chen, Catalytic decomposition of hydrogen peroxide and 2-chlorophenol with iron oxides, Water Res. 35 (2001) 2291-2299.

[170] A.L. Teel, C.R. Warberg, D.A. Atkinson, R.J. Wattsi, Comparison of mineral and soluble ion Fenton's catalysts for the treatment of trichloroethylene, Water Res. 35 (2001) 977-984.

[171] W. Kwan, B. Voelker, Influence of electrostatics on the oxidation rates of organic compounds in heterogeneous Fenton systems, Environ. Sci. Technol. 38 (2004) 3425-3431.

[172] M. Munoz, Z.M. de Pedro, J.A. Casas, J.J. Rodriguez, Preparation of magnetite-based catalysts and their application in heterogeneous Fenton oxidation - A review, Appl. Catal., B 176 (2015) 249-265. 
[173] W. Kwan, B. Voelkerb, Decomposition of hydrogen peroxide and organic compounds in the presence of dissolved iron and ferrihydrite, Environ. Sci. Technol. 36 (2002) 1467-1476.

[174] E.G. Garrido-Ramirez, B.K.G. Theng, M.L. Mora, Clays and oxide minerals as catalysts and nanocatalysts in Fenton-like reactions-A review, Appl. Clay Sci. 47 (2010) 182-192.

[175] N. Dulova, M. Trapido, A. Dulov, Catalytic degradation of picric acid by heterogeneous Fenton- based processes, Environ. Technol. 32 (2011) 439-446.

[176] J. MacGregor, E.S. Grew, J.C.M.D. Hoog, S.L. Harley, P.M. Kowalski, M.G. Yates, C.J. Carson, Boron isotopic composition of tourmaline, prismatine, and grandidierite from granulite facies paragneisses in the Larsemann Hills, Prydz Bay, East Antarctica: Evidence for a non-marine evaporite source, Geochim. Cosmochim. Acta 123 (2013) 261-283.

[177] A. Pieczka, Modeling of some structural parameters of tourmalines on the basis of their chemical composition. I. Ordered structural model, Eur. J. Mineral. 12 (2000) 589-589.

[178] F. Yavuza, A.H. Gültekin, M.C. Karakaya, CLASTOUR: a computer program for classification of the minerals of the tourmaline group, Comput. Geosci. 28 (2002) 1017-1036.

[179] P.S.R. Prasad, D.S.S. Sarma, Study of structural disorder in natural tourmalines by infrared spectroscopy, Gondwana Res. 8 (2005) 265-270.

[180] K. Krambrock, M.V.B. Pinheiro, S.M. Medeiros, K.J. Guedes, S. Schweizer, J.M. Spaeth, Investigation of radiation-induced yellow color in tourmaline by magnetic resonance, Nucl. Instrum. Methods Phys. Res., Sect. B 191 (2002) 241-245. 
[181] F.C. Hawthorne, D.M. Dirlam, Tourmaline the Indicator Mineral: From Atomic Arrangement to Viking Navigatio, Elem. 7 (2011) 307-312.

[182] A.P. Chandra, A.R. Gerson, A review of the fundamental studies of the copper activation mechanisms for selective flotation of the sulfide minerals, sphalerite and pyrite, Adv. Colloid Interface Sci. 145 (2009) 97-110.

[183] A.R. Laiju, T. Sivasankar, P.V. Nidheesh, Iron-loaded mangosteen as a heterogeneous Fenton catalyst for the treatment of landfill leachate, Environ Sci Pollut Res 21 (2014) 10900-10907.

[184] N. Miranda-Garcia, S. Suarez, B. Sanchez, J.M. Coronado, S. Malato, M.I. Maldonado, Photocatalytic degradation of emerging contaminants in municipal wastewater treatment plant effluents using immobilized $\mathrm{TiO}_{2}$ in a solar pilot plant, Appl. Catal., B 103 (2011) 294-301.

[185] B. Iurascu, I. Siminiceanu, D. Vione, M.A. Vicente, A. Gil, Phenol degradation in water through a heterogeneous photo-Fenton process catalyzed by Fe-treated laponite, Water Res. 43 (2009) 1313-1322.

[186] W. Najjar, S. Azabou, S. Sayadi, A. Ghorbel, Catalytic wet peroxide photo-oxidation of phenolic olive oil mill wastewater contaminants Part I. Reactivity of tyrosol over (Al-Fe) PILC, Appl. Catal., B 74 (2007) 11-18.

[187] R.B. Achma, A. Ghorbel, S. Sayadi, A. Dafinov, F. Medina, A novel method of copper-exchanged aluminum-pillared clay preparation for olive oil mill wastewater treatment, J. Phys. Chem. Solids 69 (2008) 1116-1120.

[188] J.Y. Feng, R.S.K. Wong, X.J. Hu, P.L. Yue, Discoloration and mineralization of Orange II by using $\mathrm{Fe}^{3+}$-doped $\mathrm{TiO}_{2}$ and bentonite clay-based $\mathrm{Fe}$ nanocatalysts, Catal. Today 98 (2004) 441-446. 
[189] S. Navalon, M. Alvaro, H. Garcia, Heterogeneous Fenton catalysts based on clays, silicas and zeolites, Appl. Catal., B 99 (2010) 1-26.

[190] P.V. Nidheesh, Heterogeneous Fenton catalysts for the abatement of organic pollutants from aqueous solution: a review, RSC Adv. 5 (2015) 40552-40577.

[191] Z.T. Hu, B. Chen, T.T. Lim, Single-crystalline $\mathrm{Bi}_{2} \mathrm{Fe}_{4} \mathrm{O}_{9}$ synthesized by low-temperature co-precipitation: performance as photo- and Fenton catalysts, RSC Adv. 4 (2014) 27820-27829.

[192] I. Nedkov, T. Merodiiska, L. Slavov, R.E. Vandenberghe, Y. Kusano, J. Takada, Surface oxidation, size and shape of nano-sized magnetite obtained by co-precipitation, J. Magn. Magn. Mater. 300 (2006) 358-367.

[193] L.M. Pastrana-Martinez, H.T. Gomes, G. Drazic, J.L. Faria, A.M.T. Silva, Hydrothermal synthesis of iron oxide photo-Fenton catalysts: the effect of parameters on morphology, particle size and catalytic efficiency, Global Nest J. 16 (2014) 474-484.

[194] T. Fried, G. Shemer, G. Markovich, Ordered two-dimensional arrays of ferrite nanoparticles, Adv. Mater. 13 (2001) 1158-1161.

[195] S.Z. Wang, H.W. Xin, Y.T. Qian, Preparation of nanocrystalline $\mathrm{Fe}_{3} \mathrm{O}_{4}$ by $\gamma$ -ray radiation, Mater. Lett. 33 (1997) 113-116.

[196] Y.B. Khollam, S.R. Dhage, H.S. Potdar, S.B. Deshpande, P.P. Bakare, S.D. Kulkarni, S.K. Date, Microwave hydrothermal preparation of submicron-sized spherical magnetite $\left(\mathrm{Fe}_{3} \mathrm{O}_{4}\right)$ powders, Mater. Lett. 56 (2002) 571-577.

[197] M.R. Tara, A.H. Ibrahim, Characterization of nano zero-valent iron (nZVI) and its application in sono-Fenton process to remove COD in palm oil mill effluent, J. Environ. Chem. Eng. 2 (2014) 1-8. 
[198] O.E. Manz, Worldwide production of coal ash and utilization in concrete and other products, Fuel 76 (1997) 691-696.

[199] Y. Chen, F. Wu, Y.X. Lin, N.S. Deng, N. Bazhin, E. Glebov, Photodegradation of glyphosate in the ferrioxalate system, J. Hazard. Mater. 148 (2007) 360-365.

[200] C. Fan, L. Tsui, M. Liao, Parathion degradation and its intermediate formation by Fenton process in neutral environment, Chemosphere 82 (2011) 229-236.

[201] W.Y. Huang, M. Brigante, F. Wu, K. Hanna, G. Mailhot, Development of a new homogenous photo-Fenton process using Fe(III)-EDDS complexes, J. Photochem. Photobiol., A 239 (2012) 17-23.

[202] H. Katsumata, S. Kaneco, T. Suzuki, K. Ohta, Y. Yobiko, Photo-Fenton degradation of alachlor in the presence of citrate solution, J. Photochem. Photobiol., A 180 (2006) 38-45.

[203] P. Kocot, A. Karocki, Z. Stasicka, Photochemistry of the Fe(III)-EDTA complexes, J. Photochem. Photobiol., A 179 (2006) 176-183.

[204] E. Lipczynska-Kochany, J. Kochany, Effect of humic substances on the Fenton treatment of wastewater at acidic and neutral pH, Chemosphere 73 (2008) 745-750. [205] X.J. Miao, N.N. Wang, S.S. Zhao, W.Q. Pan, P. Wang, Treatment of PNP wastewater by microwave assisted $\mathrm{Cu}(\mathrm{II})$-Fenton catalytic oxidation process, Chin. J. Environ. Eng. 8 (2014) 2299-2305.

[206] H. Zhang, H.J. Choi, C.P. Huang, Optimization of Fenton process for the treatment of landfill leachate, J. Hazard. Mater. 125 (2005) 166-174.

[207] H. Zhang, D.B. Zhang, J.Y. Zhou, Removal of COD from landfill leachate by electro-Fenton method, J. Hazard. Mater. 135 (2006) 106-111. 
[208] F.K. Yu, M.H. Zhou, X.M. Yu, Cost-effective electro-Fenton using modified graphite felt that dramatically enhanced on $\mathrm{H}_{2} \mathrm{O}_{2}$ electro-generation without external aeration, Electrochim. Acta (2015) 163 182-189.

[209] A. Ahmaruzzaman, A review on the utilization of fly ash, Prog. Energy Combust. Sci. 36 (2010) 327-363.

[210] P. Canizares, R. Paz, C. Saez, M.A. Rodrigo, Costs of the electrochemical oxidation of wastewaters: A comparison with ozonation and Fenton oxidation processes, J. Environ. Manage. 90 (2009) 410-420.

[211] J.A.S. Perez, I.M.R. Sanchez, I. Carra, A.C. Reina, J.L.C. Lopez, S. Malato, Economic evaluation of a combined photo-Fenton/MBR process using pesticides as model pollutant. Factors affecting costs, J. Hazard. Mater. 244-245 (2013) 195-203. [212] L.A. Ioannou, D. Fatta-Kassinos, Solar photo-Fenton oxidation against the bioresistant fractions of winery wastewater, J. Environ. Chem. Eng. 1 (2013) 703-712. [213] P.M. Lakshim, P. Sivashanmugam, Treatment of oil tanning effluent by electrocoagulation: Influence of ultrasound and hybrid electrode on COD removal, Sep. Purif. Technol. 116 (2013) 378-384.

[214] P. Wang, Environmental Microwave Chemistry Technology, Chemical Industry Press, Beijing, 2003.

[215] D.H. Bremner, R. Molina, F. Martinez, J.A. Melero, Y. Segura, Degradation of phenolic aqueous solutions by high frequency sono-Fenton systems (US- $\mathrm{Fe}_{2} \mathrm{O}_{3} / \mathrm{SBA}-15-\mathrm{H}_{2} \mathrm{O}_{2}$ ), Appl. Catal., B 90 (2009) 380-388.

[216] A.G. Chakinala, P.R. Gogate, A.E. Burgess, D.H. Bremner, Industrial wastewater treatment using hydrodynamic cavitation and heterogeneous advanced Fenton processing, Chem. Eng. J. 152 (2009) 498-502. 
[217] S. Papoutsakis, S. Miralles-Cuevas, N. Gondrexon, S. Baup, S. Malato, C. Pulgarin, Coupling between high-frequency ultrasound and solar photo-Fenton at pilot scale for the treatment of organic contaminants: An initial approach, Ultrason. Sonochem. 22 (2015) 527-534.

[218] Y. Segura, F. Martinez, J.A. Melero, R. Molina, R. Chand, D.H. Bremner, Enhancement of the advanced Fenton process $\left(\mathrm{Fe}^{0} / \mathrm{H}_{2} \mathrm{O}_{2}\right)$ by ultrasound for the mineralization of phenol, Appl. Catal., B 113-114 (2012) 100-106. 
Table 1 Conclusion of typical studies of the Fenton-like process alone

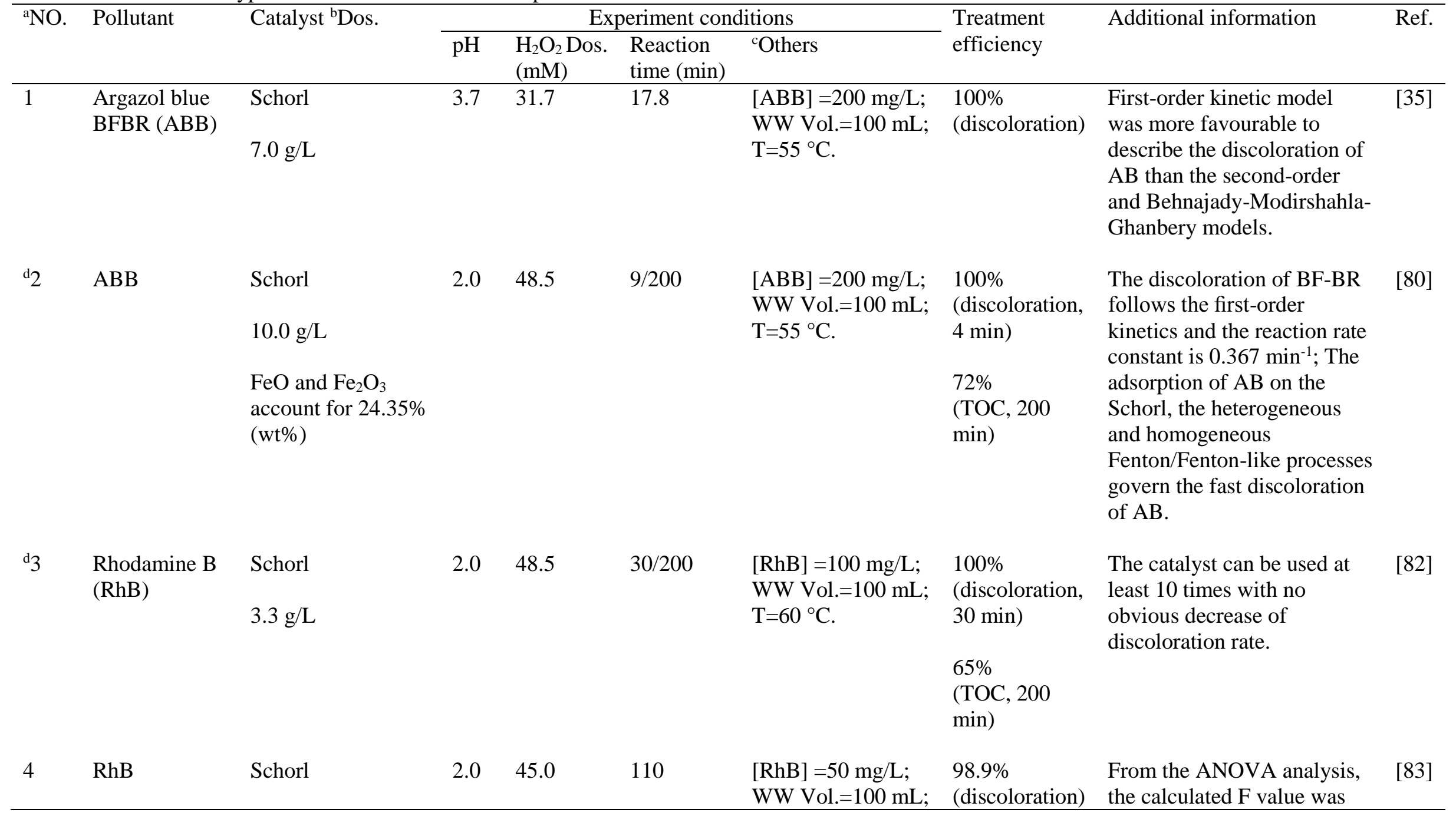


$2.5 \mathrm{~g} / \mathrm{L}$

6

Aniline

Iron oxide/ $/ \mathrm{SiO}_{2}$

6.0

50.0

$100.0 \mathrm{~g} / \mathrm{L}$

${ }^{\mathrm{f}} 7$

Chicago Sky $\quad \mathrm{Fe}^{2+} /$ Activated

Blue (CSB) carbon (AC)

Iron account for

$7 \%(\mathrm{wt} \%)$

$\mathrm{W}_{\text {cat }} / \mathrm{Q}=4.1 \mathrm{~g}$

$\mathrm{min} / \mathrm{mL}\left(\mathrm{W}_{\text {cat }}\right.$ is the

mass of catalyst

and $\mathrm{Q}$ the total feed

flow rate)

$8 \quad$ Methyl

Orange (MO)

\section{$\mathrm{Fe}^{2+} / \mathrm{NdFeB}-\mathrm{AC}$}

$3.0 \quad 0.6$

$10.0 \mathrm{~g} / \mathrm{L}$

Iron account for 94.4\% (wt \%)
$[\mathrm{MO}]=20 \mathrm{mg} / \mathrm{L} ; \quad 97 \%$ WW Vol.=200 mL; (MO) $\mathrm{T}=20{ }^{\circ} \mathrm{C}$.
$\mathrm{WW}$ COD $=1402 \quad 70 \%$ (COD)

$\mathrm{mg} / \mathrm{L}$;

$\mathrm{WW} \mathrm{BOD}_{5}=345$

$\mathrm{mg} / \mathrm{L}$;

WW Vol. $=0.8 \mathrm{~L}$.

16.14 , which is larger than

the critical value of 2.42 for

$\mathrm{F}_{0.05}(14,15)$.

$\mathrm{BOD}_{5} / \mathrm{COD}$ is increased

from 0.25 to 0.56 . The

$\mathrm{H}_{2} \mathrm{O}_{2}$ /pyrite reaction could

be active at a wide $\mathrm{pH}$ range.

The decomposition of $\mathrm{H}_{2} \mathrm{O}_{2}$

decreased with increasing

$\mathrm{M}$

(Aniline)

concentrations of $\mathrm{H}_{2} \mathrm{O}_{2}$.

The leaching iron

concentration is $0.4 \mathrm{ppm}$,

$\mathrm{WW}$ flow rate $=2.5 \quad(\mathrm{CSB})$

$\mathrm{mL} / \mathrm{min}$;

$\mathrm{T}=50{ }^{\circ} \mathrm{C}$.

$47 \%$

(TOC)

which is lower than

European limits.
The MO degradation ratio could reach $97.1 \%$ after 5 cycles; the catalytic degradation process follows the pseudo-first order kinetics model. 


\begin{tabular}{|c|c|c|c|c|c|c|c|c|c|}
\hline 9 & $\begin{array}{l}\text { Acid orange II } \\
\text { (AOII) }\end{array}$ & $\begin{array}{l}\mathrm{FeOOH}-\mathrm{C} \\
1.0 \mathrm{~g} / \mathrm{L}\end{array}$ & 5.0 & 15.0 & 120 & $\begin{array}{l}{[\mathrm{AOII}]=100 \mathrm{mg} / \mathrm{L} ;} \\
\mathrm{WW} \text { Vol. }=100 \mathrm{~mL} ; \\
\mathrm{T}=30^{\circ} \mathrm{C} .\end{array}$ & $\begin{array}{l}98 \% \\
\text { (AOII) }\end{array}$ & $\begin{array}{l}\text { A membrane module was } \\
\text { used in this work to separate } \\
\text { the solid catalyst and } \\
\text { effluent. }\end{array}$ & [84] \\
\hline${ }^{\mathrm{d}} 10$ & $\begin{array}{l}p \text {-nitrophenol } \\
(p \text {-NP) }\end{array}$ & $\begin{array}{l}\text { Coal fly ash } \\
10.0 \mathrm{~g} / \mathrm{L} \\
\mathrm{Fe}_{2} \mathrm{O}_{3} \text { account for } \\
5.73 \% \text { (wt } \%)\end{array}$ & 2.0 & 4.9 & 40 & $\begin{array}{l}{[p-\mathrm{NP}]=100 \mathrm{mg} / \mathrm{L} ;} \\
\mathrm{WW} \text { Vol. }=100 \mathrm{~mL} \\
\mathrm{~T}=25^{\circ} \mathrm{C} .\end{array}$ & $\begin{array}{l}99 \% \\
(p-\mathrm{NP})\end{array}$ & $\begin{array}{l}\text { The homogenous catalysis of } \\
\text { leached iron for } p \text {-NP } \\
\text { removal was negligible. The } \\
\text { lower reaction time and } \\
\text { higher AFA load should be } \\
\text { selected for catalytic stability } \\
\text { and reusability. }\end{array}$ & [75] \\
\hline 11 & $\begin{array}{l}\text { Sawmill } \\
\text { WW }\end{array}$ & $\begin{array}{l}\mathrm{Fe}^{3+} \\
25.0 \mathrm{mg} / \mathrm{L}\end{array}$ & 3.0 & 376.5 & 60 & $\begin{array}{l}\mathrm{COD}=3000 \mathrm{mg} / \mathrm{L} ; \\
\text { Ecotoxicity }=40 \\
\text { toxicity units; } \\
\mathrm{BOD} / \mathrm{COD}=5 \times 10^{-3} \\
; \\
\mathrm{WW} \text { Vol. }=200 \mathrm{~mL} ; \\
\mathrm{T}=120^{\circ} \mathrm{C} .\end{array}$ & $\begin{array}{l}80 \% \\
(\mathrm{COD}) \\
70 \% \\
(\mathrm{TOC})\end{array}$ & $\begin{array}{l}\text { Feeding the overall } \mathrm{H}_{2} \mathrm{O}_{2} \\
\text { amount in three times } \\
\text { throughout the reaction time } \\
\text { leads to higher efficiency } \\
\text { since this mode of } \mathrm{H}_{2} \mathrm{O}_{2} \\
\text { addition avoids high } \\
\text { concentrations of } \cdot \mathrm{OH} \text { and } \\
\text { OOH radicals at the earlier } \\
\text { oxidation stages allowing a } \\
\text { better availability of these } \\
\text { species throughout the whole } \\
\text { reaction system. }\end{array}$ & [81] \\
\hline 12 & $\begin{array}{l}\text { Malachite } \\
\text { green (MAG) }\end{array}$ & $\begin{array}{l}\mathrm{Fe}^{3+} \\
56.0 \mathrm{mg} / \mathrm{L}\end{array}$ & 3.0 & 50.0 & 15 & $\begin{array}{l}{[\mathrm{MAG}]=3.0 \times 10^{-5}} \\
\mathrm{M} ; \\
\text { Room temperature. }\end{array}$ & $\begin{array}{l}95.5 \% \\
\text { (MAG) } \\
70 \% \\
\text { (TOC) }\end{array}$ & $\begin{array}{l}\text { The degradation of } \\
\text { Malachite Green dye in the } \\
\text { Fenton-like oxidation } \\
\text { process can be described } \\
\text { with a pseudo-second-order }\end{array}$ & [62] \\
\hline
\end{tabular}


kinetic model.

13 Olive-oil mill $\mathrm{Fe}^{3+}$

WW (OMW)

$6588.4 \mathrm{mg} / \mathrm{L}$

14

OMW

$\mathrm{Fe}^{3+}$

$400.0 \mathrm{mg} / \mathrm{L}$

15 Molasses alcohol (MA)

$\mathrm{Fe}^{3+}$

$207.0 \mathrm{mg} / \mathrm{L}$

16
17ß-estradiol $\quad \mathrm{Fe}^{3+}$
(E2);
$17 \alpha$-ethinylest $\quad 58.6 \mathrm{mg} / \mathrm{L}$ radiol (EE2)

$3.0 \quad 2941.0$

180

$\mathrm{mg} / \mathrm{L}$;

$[\text { phenol }]_{\mathrm{T}}=44$

$\mathrm{mg} / \mathrm{L}$;

$\mathrm{T}=30^{\circ} \mathrm{C}$.

$4.0 \quad 882.4$

240

$\mathrm{mg} / \mathrm{L}$

Total phenol $=66.2$

$\mathrm{mg} / \mathrm{L}$;

Ambient

temperature.

7

WW COD $\mathrm{Cr}$

$=1604.7 \mathrm{mg} / \mathrm{L}$;

$\mathrm{WW}$ Vol. $=300 \mathrm{~mL}$;

$75.5 \%$

$\left(\mathrm{COD}_{\mathrm{Cr}}\right)$

WW COD $=386.5 \quad 95 \%$

$\mathrm{mg} / \mathrm{L}$;

WW BOD $=273.8$

$\mathrm{mg} / \mathrm{L}$;

$98 \%$

WW DOC $=92.5$

(EE2)

$\mathrm{mg} / \mathrm{L}$;

WW Vol. $=150 \mathrm{~mL}$;

$\mathrm{T}=25^{\circ} \mathrm{C}$. (discoloration)

(E2)

The apparent activation energy is $8.7 \mathrm{~kJ} / \mathrm{mol}$; The results show that the

Fenton-like process is a

relative cheap solution for

OMW treatment and the

treated WW can be used for

irrigation.

The optimum $\left[\mathrm{FeCl}_{3}\right] /\left[\mathrm{H}_{2} \mathrm{O}_{2}\right]$

ratio was in the range

0.026-0.058 (w/w).

$99.2 \%$

(Total

phenols)

The solution was firstly

stirred for $30 \mathrm{~s}$ at $300 \mathrm{r} / \mathrm{min}$,

and then stirred for $90 \mathrm{~s}$ at

$150 \mathrm{r} / \mathrm{min}$, finally stirred at

$50 \mathrm{r} / \mathrm{min}$ for $5 \mathrm{~min}$.

The degradation of E2 and

EE2 accord with pseudo

second order kinetics and the

activation energies were 27.8

and $22.5 \mathrm{~kJ} / \mathrm{mol}$. There was

an increase of $82 \%$ in the

BOD/COD ratio after $2 \mathrm{~h}$ of treatment. 


\begin{tabular}{|c|c|c|c|c|c|c|c|c|c|}
\hline 17 & Pulp WW & $\begin{array}{l}\mathrm{Fe}^{3+} \\
400.0 \mathrm{mg} / \mathrm{L}\end{array}$ & 3.0 & $14.7-29.4$ & $\begin{array}{l}60 \\
\text { (residence } \\
\text { time in } \\
\text { oxidation } \\
\text { reactor) }\end{array}$ & $\begin{array}{l}\text { WW COD=964 } \\
\mathrm{mg} / \mathrm{L} ; \\
\mathrm{WW} \text { BOD=400 } \\
\mathrm{mg} / \mathrm{L} ; \\
\text { Flow rate of WW } \\
\text { is } 100 \mathrm{~L} / \mathrm{h} ; \\
\text { Room temperature; } \\
\text { The oxidation } \\
\text { process by } \\
\text { Fenton-like process } \\
\text { was followed by } \\
\text { the coagulation } \\
\text { process at } \mathrm{pH}=5.0 .\end{array}$ & $\begin{array}{l}98 \% \\
\text { (discoloration) } \\
75 \%(\mathrm{COD}) \\
95 \% \\
\text { (aromatic } \\
\text { compound) }\end{array}$ & $\begin{array}{l}\text { Color is mainly removed by } \\
\text { coagulation/settling and the } \\
\text { residual hydrogen peroxide } \\
\text { is negligible after the } \\
\text { treatment. }\end{array}$ & [66] \\
\hline 18 & $\begin{array}{l}\text { Nalidixic Acid } \\
\text { (NA) }\end{array}$ & $\begin{array}{l}\mathrm{Fe}^{3+} \\
14.0 \mathrm{mg} / \mathrm{L}\end{array}$ & 3.0 & 10.0 & 60 & $\begin{array}{l}{[\mathrm{NA}]=50 \mathrm{mg} / \mathrm{L} ;} \\
\mathrm{WW} \text { Vol.=50 mL; } \\
\mathrm{T}=35^{\circ} \mathrm{C} .\end{array}$ & $\begin{array}{l}100 \% \\
\text { (NA) }\end{array}$ & $\begin{array}{l}\text { Sixteen degradation } \\
\text { intermediates were identified } \\
\text { using LC-MS. NA was } \\
\text { degraded with the } \\
\text { electrophilic attack of } \\
\text { hydroxyl radical towards the } \\
\text { C3 position. }\end{array}$ & [33] \\
\hline 19 & $\begin{array}{l}\text { Pretreated } \\
\text { cheese whey } \\
\text { WW }\end{array}$ & $\begin{array}{l}\mathrm{Fe}^{3+} \\
50.4 \mathrm{mg} / \mathrm{L}\end{array}$ & 4.2 & 200.0 & 40 & $\begin{array}{l}\mathrm{COD}=8800-10500 \\
\text { mg/L (after } \\
\text { pretreatment); } \\
\text { BOD=8-9 g/L } \\
\text { (after } \\
\text { pretreatment); } \\
\text { WW Vol=300-500 } \\
\text { mL; } \\
\text { Temperature }=19.7\end{array}$ & $\begin{array}{l}80 \% \\
(\mathrm{COD}, \\
\mathrm{WW} \\
\text { pretreated } \\
\left.\text { using } \mathrm{FeCl}_{3}\right) \text {; } \\
100 \% \\
(\mathrm{COD}, \mathrm{WW} \\
\text { pretreated }\end{array}$ & $\begin{array}{l}\text { WW was treated by the } \\
\text { Fenton-like system after } \\
\text { being pre-processed through } \\
\text { a coagulation-flocculation } \\
\text { stage. }\end{array}$ & [85] \\
\hline
\end{tabular}




\begin{tabular}{|c|c|c|c|c|c|c|c|c|c|}
\hline & & & & & & $\begin{array}{l} \pm 2.3{ }^{\circ} \mathrm{C} \text { (after } \\
\text { pretreatment using } \\
\mathrm{FeCl}_{3} \text { ); } \\
\mathrm{Or} \\
\mathrm{T}=21.4 \pm 1.3{ }^{\circ} \mathrm{C} \\
\text { (after pretreatment } \\
\left.\text { using } \mathrm{Ca}(\mathrm{OH})_{2}\right) .\end{array}$ & $\begin{array}{l}\text { using } \\
\left.\mathrm{Ca}(\mathrm{OH})_{2}\right)\end{array}$ & & \\
\hline 20 & $\begin{array}{l}\text { Benzoic Acid } \\
\text { (BA) }\end{array}$ & $\begin{array}{l}\mathrm{Fe}^{3+} \\
1.1 \mathrm{mg} / \mathrm{L} \\
\mathrm{Mn}^{2+}\end{array}$ & 3.0 & 2.0 & $25 / 180$ & $\begin{array}{l}{[\mathrm{BA}]=20 \mu \mathrm{M} ;} \\
\mathrm{WW} \text { Vol. }=100 \mathrm{~mL} ; \\
\mathrm{I}=0.05 \mathrm{M} ; \\
\mathrm{T}=25 \pm 0.5^{\circ} \mathrm{C} .\end{array}$ & $\begin{array}{l}100 \%(\mathrm{BA}, 25 \\
\min ) \\
47 \% \\
(\mathrm{TOC}, 180 \\
\min )\end{array}$ & $\begin{array}{l}\text { Addition of } \mathrm{Mn}(\mathrm{II}) \text { to the } \\
\mathrm{Fe}(\mathrm{III}) / \mathrm{H}_{2} \mathrm{O}_{2} \text { system } \\
\text { significantly enhances the } \\
\text { oxidation of BA and the } \\
\text { mechanism still accords with } \\
\text { the HO- oxidation. }\end{array}$ & {$[86]$} \\
\hline 21 & $\begin{array}{l}\text { Phenolic } \\
\text { compounds } \\
\text { from olive } \\
\text { mill WW }\end{array}$ & $\begin{array}{l}27.5 \mathrm{mg} / \mathrm{L} \\
\mathrm{Cu}^{2+} \\
500.0 \mathrm{mg} / \mathrm{L}\end{array}$ & 4.7 & 12000.0 & 65 & $\begin{array}{l}\text { WW COD }=74000 \\
\text { mg/L; } \\
\text { Total } \\
\text { polyphenol=20.56 } \\
\text { g/L; } \\
\text { WW Vol.=100 mL; } \\
\text { T=30/50 }{ }^{\circ} \mathrm{C} .\end{array}$ & $\begin{array}{l}43 \%\left(30^{\circ} \mathrm{C}\right) \\
62 \% \\
\left(50^{\circ} \mathrm{C}\right) \\
\text { (both for } \\
\text { Phenolic } \\
\text { compound }\end{array}$ & $\begin{array}{l}\text { Degradation of contaminant } \\
\text { followed first-order kinetics } \\
\text { and the activation energy } \\
\text { was } 21 \mathrm{~kJ} / \mathrm{mol} \text {. }\end{array}$ & [87] \\
\hline
\end{tabular}

\footnotetext{
a: No. 1-10 are the heterogeneous Fenton-like process and No. 11-21 are the homogeneous Fenton-like process.

b: Dos. represents dosage.

c: Vol. represents volume; $\mathrm{T}$ is the abbreviation of temperature.

$\mathrm{d}$ : Both of the adsorption and the homogeneous contribution are responsible for the treatment of the WW.

e: The homogeneous contribution is responsible for the treatment of the WW.

$\mathrm{f}$ : The adsorption plays an important role in the treatment of the WW.
} 
Table 2 Study conclusion of Fenton-like process combined with photochemistry

\begin{tabular}{|c|c|c|c|c|c|c|c|c|c|}
\hline \multirow[t]{2}{*}{${ }^{\mathrm{a}} \mathrm{NO}$. } & \multirow[t]{2}{*}{ Pollutant } & \multirow[t]{2}{*}{ Catalyst ${ }^{\mathrm{b}}$ Dos. } & \multicolumn{4}{|c|}{ Experiment conditions } & \multirow{2}{*}{$\begin{array}{l}\text { Treatment } \\
\text { efficiency }\end{array}$} & \multirow{2}{*}{$\begin{array}{l}\text { Additional } \\
\text { information }\end{array}$} & \multirow[t]{2}{*}{ Ref. } \\
\hline & & & $\mathrm{pH}$ & $\begin{array}{l}\mathrm{H}_{2} \mathrm{O}_{2} \text { Dos. } \\
(\mathrm{mM})\end{array}$ & $\begin{array}{l}\text { Reaction } \\
\text { time (min) }\end{array}$ & ${ }^{\circ}$ Others & & & \\
\hline 1 & $\begin{array}{l}\text { Naproxen } \\
\text { (NPX) }\end{array}$ & $\begin{array}{l}\text { Hydrated hematite } \\
\left(\text { hyd- } \mathrm{Fe}_{2} \mathrm{O}_{3}\right) ; \\
\text { Hematite }\left(\mathrm{Fe}_{2} \mathrm{O}_{3}\right) \\
\text { Magnetite }\left(\mathrm{Fe}_{3} \mathrm{O}_{4}\right) \\
0.05 \mathrm{~g} / \mathrm{L}\end{array}$ & $6.5 \pm 0.5$ & $13.0 \pm 1.3$ & 120 & $\begin{array}{l}\text { Xenon arc lamp }(2700 \\
\left.\mathrm{kJ} / \mathrm{hm}^{2}, 300-800 \mathrm{~nm}\right) \\
\text { Temperature }=25{ }^{\circ} \mathrm{C} ; \\
{[\text { NPX] }=10 \mathrm{mg} / \mathrm{L} ;} \\
\text { NPX total Vol. }=1 \mathrm{~L} ; \\
\text { Treated Vol. }=200 \mathrm{ml} \text {. }\end{array}$ & $\begin{array}{l}50 \%-60 \% \\
(\mathrm{TOC})\end{array}$ & $\begin{array}{l}\text { Zeolite was studied } \\
\text { in this work, and in } \\
\text { the presence of } \\
\text { Zeolite, photolysis of } \\
\text { NPX is accelerated. }\end{array}$ & [104] \\
\hline 2 & Phenol & $\begin{array}{l}\text { Magnetite } \\
0.2 \mathrm{~g} / \mathrm{L} \\
\mathrm{Fe}^{\mathrm{II}} / \mathrm{Fe}^{\mathrm{III}}=0.30-0.43\end{array}$ & 5.0 & $\begin{array}{l}5 \\
\left(\mathrm{Na}_{2} \mathrm{~S}_{2} \mathrm{O}_{8}\right)\end{array}$ & 4 & $\begin{array}{l}\text { UVA=20 W } \\
(295-400 \mathrm{~nm} ; \max \\
\text { emission=365 nm); } \\
{[\text { Phenol] }=9.4 \mathrm{mg} / \mathrm{L} \text {; }} \\
\text { WW Vol. =50 mL; } \\
\text { T=30 }{ }^{\circ} \mathrm{C} .\end{array}$ & $\begin{array}{l}98 \% \\
\text { (phenol) }\end{array}$ & $\begin{array}{l}\text { Sulphate radical is a } \\
\text { strong one-electron } \\
\text { oxidant; although } \\
\text { magnetite naturally } \\
\text { contains } \mathrm{Fe}^{\mathrm{II}} \text {, the } \\
\text { air-exposed oxide } \\
\text { surface is fully } \\
\text { oxidized to } \mathrm{Fe}^{\mathrm{III}} \text { and } \\
\text { irradiation is required } \\
\text { to produce } \mathrm{Fe}^{\mathrm{II}} \text {. }\end{array}$ & [101] \\
\hline $\mathrm{d}_{3}$ & $\begin{array}{l}\text { Reactive } \\
\text { Orange } 29 \\
\text { (RO29) }\end{array}$ & $\begin{array}{l}\text { Lepidocrocite-granu } \\
\text { lar activated carbon } \\
\text { nano composite } \\
(\gamma \text {-FeOOH-GAC) } \\
5.0 \mathrm{~g} / \mathrm{L}\end{array}$ & 2.0 & 3.3 & 50 & $\begin{array}{l}10 \mathrm{UV} \text { LED lamps on } \\
\text { the top of the WW } \\
\text { solution with } 4 \mathrm{~cm} \\
\text { distance from solution } \\
\text { surface; } \\
\text { WW COD=420 mg/L; } \\
\text { WW pH=6.8; } \\
\text { WW conductivity= } \\
3.09 \mathrm{mS} / \mathrm{cm} \text {; } \\
\text { WW Vol.=400 mL; }\end{array}$ & $\begin{array}{l}81 \% \\
\text { (Decolor- } \\
\text { ization) }\end{array}$ & $\begin{array}{l}\text { Photo Fenton-like } \\
\text { process has higher } \\
\text { capacity on treating } \\
\text { WW than } \\
\text { Fenton-like process, } \\
\text { photocatalytic, } \\
\text { adsorption, } \\
\text { photolysis, and } \\
\mathrm{H}_{2} \mathrm{O}_{2} / \mathrm{UV} \text { processes. }\end{array}$ & [105] \\
\hline
\end{tabular}


Flow rate $=1.98$

$\mathrm{ml} / \mathrm{min}$.

\begin{tabular}{|c|c|c|c|c|c|c|c|c|c|}
\hline 4 & $\begin{array}{l}\text { Acid Orange } \\
7 \\
\text { (AO7) } \\
\text { Phenol }\end{array}$ & $\begin{array}{l}\alpha-\mathrm{Fe}_{2} \mathrm{O}_{3} / \mathrm{S} \\
0.1 \mathrm{~g} / \mathrm{L}\end{array}$ & 6.9 & 1.9 & $14 / 60$ & $\begin{array}{l}\text { High-pressure } \mathrm{Hg} \\
\text { lamp power= } 300 \mathrm{~W} \text {; } \\
\text { OR } \\
\text { Halogen lamp } \\
\text { power }=1000 \mathrm{~W} ; \\
{[\mathrm{AO}]=35 \mathrm{mg} / \mathrm{L} ;} \\
{[\mathrm{Phenol}]=40 \mathrm{mg} / \mathrm{L} ;} \\
\text { WW Vol.=100 mL. }\end{array}$ & $\begin{array}{l}95 \% \\
\text { (AO7, 14 } \\
\text { min, vis); } \\
100 \% \\
\text { (AO7, } 60 \\
\text { min, UV); } \\
85 \% \\
\text { (phenol, } \\
60 \text { min, } \\
\text { UV or } \\
\text { vis) }\end{array}$ & $\begin{array}{l}\alpha-\mathrm{Fe}_{2} \mathrm{O}_{3} / \mathrm{S} \text { showed } \\
\text { little Fenton } \\
\text { reactivity in the dark, } \\
\text { but had an excellent } \\
\text { heterogeneous } \\
\text { Fenton activity under } \\
\text { either UV or visible } \\
\text { irradiation. Other } \\
\text { kinds of } \alpha-\mathrm{Fe}_{2} \mathrm{O}_{3} \text { had } \\
\text { no activation. }\end{array}$ & [106] \\
\hline $\mathrm{d}_{5}$ & $\begin{array}{l}\text { Reactive } \\
\text { Red 195 } \\
\text { (RR195) }\end{array}$ & $\begin{array}{l}\text { Iron(III)-alginate } \\
\text { fiber complex } \\
5.0 \mathrm{~g} / \mathrm{L} \\
\mathrm{Fe} \text { content is } \\
\text { affected by the Fe } \\
\text { concentration during } \\
\text { preparation. }\end{array}$ & 6.0 & 3.0 & 100 & $\begin{array}{l}\text { Visible light }(9.65 \\
\text { W/cm }{ }^{2} \text {, wavelength }= \\
400-1000 \mathrm{~nm} ;) \\
\text { UV irradiation }(365 \\
\left.\mathrm{nm} ; 2.51 \mathrm{~W} / \mathrm{cm}^{2}\right) \\
{[\mathrm{RR} 195]=0.05 \mathrm{mM} ;} \\
\mathrm{T}=25{ }^{\circ} \mathrm{C} .\end{array}$ & $\begin{array}{l}79 \% \\
\text { (TOC) }\end{array}$ & $\begin{array}{l}\text { The catalytic activity } \\
\text { is affected by } \\
\mathrm{Na}_{2} \mathrm{SO}_{4} \text { or } \mathrm{NaCl} \\
\text { slightly and can keep } \\
\text { at constant after four } \\
\text { recycles of use. }\end{array}$ & [107] \\
\hline 6 & $\begin{array}{l}\text { Rhodamine } \\
\text { 6G (R6G) } \\
\text { Methyl Bule } \\
\text { (MB) } \\
\text { Methyl }\end{array}$ & $\begin{array}{l}\text { Layered Fe-titanate } \\
0.3 \mathrm{~g} / \mathrm{L}\end{array}$ & $\begin{array}{l}6.5 \\
(\mathrm{R} 6 \mathrm{G}) \\
5.6 \\
(\mathrm{MB}) \\
6.7\end{array}$ & $\begin{array}{l}0.5(\mathrm{R} 6 \mathrm{G}) \\
10.0(\mathrm{MB}) \\
11.7(\mathrm{MO})\end{array}$ & 15 & $\begin{array}{l}\text { Hg lamp power }=500 \\
\text { W (305-387 } \mathrm{nm}) ; \\
\text { R6G Con. }=5.99 \mathrm{mg} / \mathrm{L} \text {; } \\
\text { MB Con. }=23994 \\
\mathrm{mg} / \mathrm{L} ;\end{array}$ & $\begin{array}{l}98 \% \\
(\mathrm{R} 6 \mathrm{G}) \\
\\
98.5 \% \\
(\mathrm{MB})\end{array}$ & $\begin{array}{l}\text { Fe-titanates possess } \\
\text { layered structures, } \\
\text { and } \mathrm{Fe}^{3+} \text { ions located } \\
\text { in the interlayer. The } \\
\text { leakage of } \mathrm{Fe} \text { is }\end{array}$ & [108] \\
\hline
\end{tabular}




\begin{tabular}{|c|c|c|c|c|c|c|c|c|c|}
\hline & $\begin{array}{l}\text { Orange } \\
(\mathrm{MO})\end{array}$ & & $(\mathrm{MO})$ & & & $\begin{array}{l}\text { MO Con. }=19640 \\
\mathrm{mg} / \mathrm{L} ; \\
\text { Vol.=30 mL; } \\
\mathrm{T}=25{ }^{\circ} \mathrm{C} .\end{array}$ & $\begin{array}{l}97 \% \\
\text { (MO) }\end{array}$ & $\begin{array}{l}\text { almost negligible } \\
\text { under optimal pH } \\
\text { and can be used for } \\
\text { at least } 4 \text { cycles with } \\
\text { effective remove of } \\
\text { pollutants. }\end{array}$ & \\
\hline 7 & $\begin{array}{l}\text { Petroleum } \\
\text { hydrocarbon } \\
\text { (TPH) }\end{array}$ & $\begin{array}{l}\text { Nano zero-valent } \\
\text { iron } \\
0.02 \mathrm{~g} / \mathrm{L}\end{array}$ & 3.0 & 5.0 & 60 & $\begin{array}{l}\text { UV lamp power }=125 \\
\mathrm{~kW} ; \\
\mathrm{UV} \text { wavelength }=247.3 \\
\mathrm{~nm} ; \\
{[\mathrm{TPH}]=0.7 \mathrm{mg} / \mathrm{L} ;} \\
\mathrm{T}=24-26{ }^{\circ} \mathrm{C} .\end{array}$ & $\begin{array}{l}95.8 \% \\
\text { (TPH) }\end{array}$ & $\begin{array}{l}\text { Degree of } \\
\text { significance for TPH } \\
\text { Con., nZVI dosage, } \\
\mathrm{H}_{2} \mathrm{O}_{2} \text { dosage, pH and } \\
\text { reaction time are } \\
7.643,9.33,13.318, \\
15.185 \text { and } 6.588 \%, \\
\text { respectively. } \\
\text { Photo-Fenton like } \\
\text { process using nZVI } \\
\text { could be used as a } \\
\text { pretreatment. }\end{array}$ & [38] \\
\hline 8 & $\begin{array}{l}\text { Neutral Red } \\
(\mathrm{NR}) \\
\text { Azure-B } \\
(\mathrm{AB})\end{array}$ & $\begin{array}{l}\text { Copper } \\
\text { Pyrovanadate } \\
0.05 \text { g/L (NR) } \\
0.06 \text { g/L (AB) }\end{array}$ & $\begin{array}{l}8.0 \\
(\mathrm{NR}) \\
6.0 \\
(\mathrm{AB})\end{array}$ & $\begin{array}{l}4.0(\mathrm{NR}) \\
5.0(\mathrm{AB})\end{array}$ & 120 & $\begin{array}{l}\text { Tungsten lamp } \\
\text { power }=200 \mathrm{~W} ; \\
\mathrm{T}=25{ }^{\circ} \mathrm{C} ; \\
{[\mathrm{NR}]=7 \times 10^{-5} \mathrm{M} \text {; }} \\
{[\mathrm{AB}]=1.2 \times 10^{-5} \mathrm{M} \text {; }} \\
\text { WW Vol. }=1 \mathrm{~L} \text {. }\end{array}$ & $\begin{array}{l}75 \%(\mathrm{NR}, \\
\mathrm{COD}) \\
60 \%(\mathrm{AB}, \\
\mathrm{COD})\end{array}$ & $\begin{array}{l}\text { Degradation accord } \\
\text { with pseudo-first- } \\
\text { order reaction, rate } \\
\text { constant is } \\
2.081 \times 10^{-4} \mathrm{sec}^{-1} \text { and } \\
3.876 \times 10^{-4} \mathrm{sec}^{-1} \text { for } \\
\text { neutral red and } \\
\text { azure-B. The catalyst } \\
\text { activity decreases } \\
\text { slightly, only around } \\
5 \% \text { in the } 5 \text { th run } \\
\text { after } 30 \text { min reaction. }\end{array}$ & [92] \\
\hline
\end{tabular}




\begin{tabular}{|c|c|c|c|c|c|c|c|c|c|}
\hline 9 & $\begin{array}{l}\text { Orange II } \\
(\mathrm{O} 2)\end{array}$ & $\begin{array}{l}\mathrm{Cu} / \mathrm{MCM}-41 \\
1.0 \mathrm{~g} / \mathrm{L}\end{array}$ & 7.0 & 14.4 & 120 & $\begin{array}{l}\text { UV-C lamp power }=8 \\
\mathrm{~W} ; \\
{[\mathrm{O} 2]=0.3 \mathrm{mM}} \\
\text { WW Vol.=200 L; } \\
\mathrm{T}=35{ }^{\circ} \mathrm{C} .\end{array}$ & $\begin{array}{l}70 \% \\
\text { (TOC) }\end{array}$ & $\begin{array}{l}\text { TOC removal rate } \\
\text { keeps constant after } \\
\text { four cycles. The } \\
\text { leaching of the } \\
\text { developed catalyst is } \\
\text { below } 0.5 \mathrm{mg} / \mathrm{L} \text {. }\end{array}$ & [93] \\
\hline 10 & $\begin{array}{l}\text { Citric acid } \\
\text { and COD in } \\
\text { naval } \\
\text { derusting } \\
\text { WW }\end{array}$ & $\begin{array}{l}\mathrm{Fe}^{3+} \\
\text { WW contain high } \\
\text { concentration } \mathrm{Fe}^{3+} \\
\text { ion and no need to } \\
\text { add it externally. }\end{array}$ & $2.5-5.5$ & 3900 & 1080 & $\begin{array}{l}\text { Medium-pressure } \\
\text { mercury-vaporized } \\
\text { lamp power=450 W; } \\
\text { UV energy-40-48\%, } \\
\text { Visible } \\
\text { energy-40-43\%, } \\
\text { Infrared-The rest; } \\
\text { WW COD=46700 } \\
\text { mg/L; } \\
\text { WW Vol. }=800 \mathrm{~mL} ; \\
\mathrm{T}=40 \pm 3{ }^{\circ} \mathrm{C} .\end{array}$ & $\begin{array}{l}93 \% \\
\text { (COD) }\end{array}$ & $\begin{array}{l}\text { In the experiment of } \\
\text { the real naval } \\
\text { desusting WW, } \mathrm{H}_{2} \mathrm{O}_{2} \\
\text { was added multiple } \\
\text { times, and the } \\
\text { treatment efficiency } \\
\text { is better using } \\
\text { multiple points than } \\
\text { that in one point. }\end{array}$ & [99] \\
\hline 11 & K-acid & $\begin{array}{l}\mathrm{Fe}^{3+} \\
28.0 \mathrm{mg} / \mathrm{L}\end{array}$ & 3.0 & 30.0 & 60 & $\begin{array}{l}\text { UV-C-2.5 W/m²; } \\
\left(\mathrm{UV}-\mathrm{A}-8.1 \mathrm{~W} / \mathrm{m}^{2} ;\right. \\
\text { Visible light-6.0 } \\
\left.\mathrm{W} / \mathrm{m}^{2}\right) ; \\
{[\mathrm{K}-\text { acid }]=715 \mathrm{mg} / \mathrm{L} ;} \\
\text { WW COD=450 mg/L; } \\
\text { WW TOC=130 mg/L. }\end{array}$ & $\begin{array}{l}99 \% \\
\text { (K-acid) } \\
95 \% \\
\text { (COD) } \\
90.5 \% \\
\text { (TOC) }\end{array}$ & $\begin{array}{l}\text { The treatment } \\
\text { efficiencies of K-acid } \\
\text { WW are similar } \\
\text { under UV-C, UV-A } \\
\text { or visible light } \\
\text { respectively. The } \\
\text { degradation route of } \\
\text { K-acid would be } \\
\text { multistep } \\
\text { hydroxylation via } \\
\text { HO. attack and } \\
\text { desulphonation or the }\end{array}$ & [100] \\
\hline
\end{tabular}


sulphonate group.

12 Bromocresol $\mathrm{Fe}^{3+}$

green

(BCG) $\quad 5.6 \mathrm{mg} / \mathrm{L}$
Phenol Red $\mathrm{Fe}^{3+}$
(PR)
$1.7 \mathrm{mg} / \mathrm{L}$$$
1.7 \mathrm{mg} / \mathrm{L}
$$

$0.12 \mathrm{~mL}$
(30\%)

60

0.1

130

$\begin{array}{ll}14 \text { Inderal } & \mathrm{Fe}^{3+} / \text { catechin } \\ & \\ & 50.0 \mathrm{uM} \\ \left(\mathrm{Fe}^{3+}\right)\end{array}$
6.0
$\mathrm{H}_{2} \mathrm{O}_{2}$ was generated
by the

photoch-
120
Xenon short-arc lamp power $=150 \mathrm{~W}$; wavelength $>300 \mathrm{~nm}$; [Inderal] $=10 \mu \mathrm{M}$;
Three low pressure
mercury lamps tota power $=45 \mathrm{~W}$;

$[\mathrm{BCG}]=6 \times 10^{-5} \mathrm{M}$;

WW Vol. $=100 \mathrm{~mL}$.

$100 \%$
(BCG)

Results showed that

color removal

followed the

increasing order:

$\mathrm{Fe}(\mathrm{III}) / \mathrm{H}_{2} \mathrm{O}_{2}<\mathrm{Fe}(\mathrm{II}) /$

$\mathrm{H}_{2} \mathrm{O}_{2}<$

$\mathrm{Fe}(\mathrm{II}) / \mathrm{H}_{2} \mathrm{O}_{2} /$ Solar

$<\mathrm{Fe}(\mathrm{II}) / \mathrm{H}_{2} \mathrm{O}_{2} / \mathrm{UV} 254$

${ }_{\mathrm{nm}}<\mathrm{Fe}(\mathrm{III}) / \mathrm{H}_{2} \mathrm{O}_{2} / \mathrm{UV} 2$

$54_{\mathrm{nm}}$.

Tungsten lamp power=

94\% (PR)

$200 \mathrm{~W}$;

Light intensity $=60$

$\mathrm{mW} / \mathrm{cm}$;

$[\mathrm{PR}]=1.33 \times 10^{-4} \mathrm{M}$.

The ferric ions on exposure to light generate a proton and $\cdot \mathrm{OH}$ radicals and it is reduced to
[97] ferrous state. These ferrous ions further react with $\mathrm{H}_{2} \mathrm{O}_{2}$ producing $\cdot \mathrm{OH}$ and oxidized back to ferric ions.
75\% The degree and rate (inderal) of Inderal
degradation at near-neutral $\mathrm{pH}$ were 


\begin{tabular}{|c|c|c|c|c|c|c|c|c|c|}
\hline & & 200.0 uM (catechin) & & $\begin{array}{l}\text { emical } \\
\text { process. }\end{array}$ & & WW Vol. $=50 \mathrm{~mL}$. & & $\begin{array}{l}\text { markedly increased } \\
\text { upon use of the } \\
\text { Fe(III)-catechin } \\
\text { complex. }\end{array}$ & \\
\hline 15 & $\begin{array}{l}\text { Antibiotic } \\
\text { Fermentatio } \\
\mathrm{n}\end{array}$ & $\begin{array}{l}\mathrm{Fe}^{3+} / \text { Oxalic acid } \\
\mathrm{Fe}^{3+} \text { comes from the } \\
\text { coagulant } \\
\text { (PolyferricSulfate) } \\
\text { after coagulation } \\
\text { process. }\end{array}$ & 7.0 & 4.4 & 60 & $\begin{array}{l}\text { UV power }=30 \mathrm{~W} ; \\
\text { UV wavelength=254 } \\
\text { nm; } \\
{[\text { Oxalic acid }]=45} \\
\text { mg/L; } \\
\mathrm{T}=20 \pm 2{ }^{\circ} \mathrm{C} .\end{array}$ & $\begin{array}{l}96.7 \% \\
\text { (Decolor- } \\
\text { ization) } \\
93.5 \% \\
\text { (COD) }\end{array}$ & $\begin{array}{l}\text { Coagulation process } \\
\text { was used before the } \\
\text { photo-Fenton-like } \\
\text { process. }\end{array}$ & [109] \\
\hline 16 & $\begin{array}{l}\text { Diclofenac } \\
(\mathrm{DCF}) \\
\text { Carbamazep } \\
\text { ine (CBZ) }\end{array}$ & $\begin{array}{l}\mathrm{Cu}^{2+} \\
1.0 \mathrm{uM}\end{array}$ & 7.0 & 10.0 & 240 & $\begin{array}{l}\text { Six 4-W Black Light } \\
\text { Blue lamps; } \\
\text { Max wavelength }=365 \\
\mathrm{~nm} ; \\
{[\mathrm{DCF}]=[\mathrm{CBZ}]=1 \mu \mathrm{M} \text {; }} \\
\mathrm{T}=22 \pm 2{ }^{\circ} \mathrm{C} .\end{array}$ & $\begin{array}{l}47 \% \\
(\mathrm{DCF}) \\
66 \% \\
(\mathrm{CBZ})\end{array}$ & $\begin{array}{l}\text { The } \mathrm{UV} / \mathrm{Cu}(\mathrm{II}) / \mathrm{H}_{2} \mathrm{O}_{2} \\
\text { system is much more } \\
\text { efficient than the } \\
\mathrm{Cu}(\mathrm{II}) / \mathrm{H}_{2} \mathrm{O}_{2} \text { system } \\
\text { due to the enhanced } \\
\text { reduction of } \mathrm{Cu}(\mathrm{II}) \\
\text { by } \cdot \mathrm{HO}_{2} \text { or } \mathrm{O}_{2}^{-} \cdot\end{array}$ & [95] \\
\hline 17 & $\begin{array}{l}\text { Methel } \\
\text { Orange } \\
(\mathrm{MO})\end{array}$ & $\begin{array}{l}{[\mathrm{Cu}(\mathrm{HL}) \mathrm{Cl}](1)} \\
\mathrm{OR} \\
{[\mathrm{Cu}(\mathrm{HL}) \mathrm{Br}](2)} \\
3.11 \times 10^{-6} \mathrm{M} \\
\mathrm{HL} \text { is the } \\
\text { multidentate } \\
\text { schiffbase } \\
\mathrm{N}-[(2 \text {-oxy-acetate)-b } \\
\text { enzyl]- 2-aminotha- }\end{array}$ & $\begin{array}{l}6.5 \text { for } \\
(1) \text {; } \\
6.7 \text { for } \\
(2)\end{array}$ & 24 & 2 & $\begin{array}{l}\text { UV power }=300 \mathrm{~W} \\
{[\mathrm{MO}]=2 \times 10^{-5} \mathrm{M}} \\
\text { Ambient temperature. }\end{array}$ & $\begin{array}{l}97 \% \\
\text { (MO, for } \\
(1)) \\
88 \% \\
\text { (MO, for } \\
(2))\end{array}$ & $\begin{array}{l}\text { The photocatalytic } \\
\text { property of this type } \\
\text { of complex has some } \\
\text { relationship with } \\
\text { structure. }\end{array}$ & [39] \\
\hline
\end{tabular}


nol

Soluble bio-organic 7.0
substances

Medium-pressure

mercury arc lamp

power $=125 \mathrm{~W}$;

wavelength $>300 \mathrm{~nm}$;

$25.0 \mathrm{mg} / \mathrm{L}$
$[\mathrm{CV}]=10 \mathrm{mg} / \mathrm{L}$;

$\mathrm{T}=25^{\circ} \mathrm{C}$.
66.7 Dissolved organic

(Decolor- matter (DOM) has

ization)

received much

attention from

researchers in recent

years because of its

photochemical

properties. SBO was

isolated from urban

biorefuses.

\footnotetext{
a: No. 1-9 are the heterogeneous Fenton-like process and No.10-18 are the homogeneous Fenton-like process

b: Dos. represents dosage

d: Vol. represents volume; T represents temperature.

$\mathrm{d}$ : The adsorption plays an important role in the treatment of WW.
} 
Table 3 Study conclusion of Fenton-like process combined with electrochemistry

\begin{tabular}{|c|c|c|c|c|c|c|c|c|c|}
\hline \multirow[t]{2}{*}{${ }^{\mathrm{N} N O}$. } & \multirow[t]{2}{*}{ Pollutant } & \multirow{2}{*}{$\begin{array}{l}\text { Catalyst } \\
\text { bDos. } \\
\text { /Cathode }\end{array}$} & \multicolumn{4}{|c|}{ Experiment conditions } & \multirow{2}{*}{$\begin{array}{l}\text { Treatment } \\
\text { efficiency }\end{array}$} & \multirow[t]{2}{*}{ Additional information } & \multirow[t]{2}{*}{ Ref. } \\
\hline & & & $\mathrm{pH}$ & $\begin{array}{l}\mathrm{H}_{2} \mathrm{O}_{2} \text { Dos. } \\
(\mathrm{mM})\end{array}$ & $\begin{array}{l}\text { Reaction } \\
\text { time (min) }\end{array}$ & ${ }^{\mathrm{c}}$ Others & & & \\
\hline 1 & $\begin{array}{l}\text { Lissamine } \\
\text { Green B } \\
\text { (LGB) } \\
\text { pirimicarb }\end{array}$ & $\begin{array}{l}\text { Acid mine } \\
\text { drainage } \\
\text { sludge / } \\
\text { alginate gel } \\
\text { beads } \\
\text { (AMDS/AB) } \\
20.0 \mathrm{~g} / \mathrm{L} \\
\mathrm{Fe} \\
\text { concentration } \\
\text { is } 26350 \mathrm{ppm}\end{array}$ & 2.0 & $\begin{array}{l}\mathrm{H}_{2} \mathrm{O}_{2} \text { was } \\
\text { generated } \\
\text { in situ. }\end{array}$ & $\begin{array}{l}60 \text { (LGB) } \\
180 \\
\text { (pirimicar- } \\
\text { b) }\end{array}$ & $\begin{array}{l}\text { Electrodes are } \\
\text { graphite sheets with } \\
60 \mathrm{~mm} \text { distance; } \\
\text { Electrolyte is } \mathrm{Na}_{2} \mathrm{SO}_{4} \\
\text { with } 0.01 \mathrm{M} ; \\
\text { Voltage }=5 \mathrm{~V}(\mathrm{DC}) ; \\
{[\mathrm{LGB}]=10 \mathrm{mg} / \mathrm{L} ;} \\
{[\text { Pirimicarb] }=100} \\
\mathrm{mg} / \mathrm{L} ; \\
\mathrm{WW} \text { Vol. }=0.15 \mathrm{~L} \text {. } \\
\text { Air flow rate }=1 \\
\mathrm{~L} / \mathrm{min} \text { (cathode } \\
\text { surface, started } 10 \\
\text { min ahead of time) }\end{array}$ & $\begin{array}{l}99 \% \\
\text { (decolorat- } \\
\text { ion of } \\
\text { LGB); } \\
98 \% \\
\text { (degradati- } \\
\text { on of } \\
\text { pirimicarb) }\end{array}$ & $\begin{array}{l}\text { The decoloration rate of LGB } \\
\text { is } 87 \% \text { at } \mathrm{pH}=6 \text { after } 60 \mathrm{~min} \text {; } \\
\text { AMDS can act as a catalyst at } \\
\mathrm{pH}=6 \text {, because metal will leach } \\
\text { out at } \mathrm{pH}=2 \text {; Alginate gel } \\
\text { beads was used to immobilize } \\
\text { the metal on AMDS in order to } \\
\text { stop the leaching of metal } \\
\text { when AMDS works at low } \mathrm{pH} \text {. }\end{array}$ & [41] \\
\hline 2 & $\begin{array}{l}\text { sulforhoda } \\
\text { mine B } \\
\text { (SRB) } \\
2,4 \text {-dichlor } \\
\text { ophenol } \\
(2,4-D C P)\end{array}$ & $\begin{array}{l}\mathrm{Co}_{3} \mathrm{O}_{4} \text {-graph- } \\
\text { ite cathode }\end{array}$ & $\begin{array}{l}2.0- \\
10.0\end{array}$ & $\begin{array}{l}\mathrm{H}_{2} \mathrm{O}_{2} \text { was } \\
\text { generated } \\
\text { by } \mathrm{Co}_{3} \mathrm{O}_{4-} \\
\text { graphite } \\
\text { cathode } \\
\text { from pH } \\
2-10 .\end{array}$ & $\begin{array}{l}150(\mathrm{SRB}) \\
240 \\
(2,4-\mathrm{DCP})\end{array}$ & $\begin{array}{l}\text { Cathode is } \\
\mathrm{Co}_{3} \mathrm{O}_{4} \text {-graphite; } \\
\text { Anode is Pt net }(1.0 \\
\left.\mathrm{cm}^{2}\right) \text {; } \\
\text { Electrolyte is } \mathrm{Na}_{2} \mathrm{SO}_{4} \\
\text { with } 10 \mathrm{~g} / \mathrm{L} ; \\
\text { Voltage }=6 \mathrm{~V}(\mathrm{DC}) ; \\
{[\mathrm{SRB}]=1.0 \times 10^{-5} \mathrm{M} ;} \\
{[2,4-\mathrm{DCP}]=1.0 \times 10^{-3}} \\
\mathrm{M} ; \\
\mathrm{WW} \text { Vol. }=50 \mathrm{~mL} ; \\
\mathrm{T}=20^{\circ} \mathrm{C} .\end{array}$ & $\begin{array}{l}100 \% \\
\text { (SRB) } \\
98.6 \% \\
(2,4-\mathrm{DCP})\end{array}$ & $\begin{array}{l}\text { The removal rate of SRB did } \\
\text { not decrease obviously after } \\
\text { catalyst was used for five } \\
\text { times; The } \mathrm{Co}_{3} \mathrm{O}_{4} \text { - graphite } \\
\text { composite electrode displays } \\
\text { good electrochemical } \\
\text { characteristics and can } \\
\text { produces } \mathrm{H}_{2} \mathrm{O}_{2} \text { and } \cdot \mathrm{OH} \text { from } \\
\text { pH 2-10. }\end{array}$ & [115] \\
\hline
\end{tabular}




\begin{tabular}{|c|c|c|c|c|c|c|c|c|c|}
\hline 3 & Phenol & $\begin{array}{l}\text { Nano zero- } \\
\text { valent iron } \\
0.5 \mathrm{~g} / \mathrm{L}\end{array}$ & 6.2 & 14.7 & 30 & $\begin{array}{l}\text { Electrodes are } \\
\text { stainless steel with } 50 \\
\text { mm distance; } \\
\text { Surface area of } \\
\text { electrodes }=25 \mathrm{~cm}^{2} ; \\
\text { Current density }=12 \\
\mathrm{~mA} / \mathrm{cm}^{2} ; \\
\text { Electrolyte is } \mathrm{Na}_{2} \mathrm{SO}_{4} \\
\text { with } 1 \mathrm{~g} / \mathrm{L} ; \\
\text { Low pressure } \\
\text { mercury lamp=8 W } \\
(254 \mathrm{~nm}) ; \\
\text { [Phenol] }=200 \mathrm{mg} / \mathrm{L} ; \\
\text { WW Vol.=1 L. }\end{array}$ & $\begin{array}{l}100 \% \\
\text { (Phenol) }\end{array}$ & $\begin{array}{l}\text { The removal rate constant } \\
\text { ( } k_{\text {obs }} \text { ) was proportional to the } \\
\text { NZVI and } \mathrm{H}_{2} \mathrm{O}_{2} \text { dosage and } \\
\text { inversely proportional to the } \\
\text { initial phenol concentration } \\
\text { and initial pH of the solution; } \\
\mathrm{H}_{2} \mathrm{O}_{2} \text { can be generated also by } \\
\text { electrolysis in the system. }\end{array}$ & [37] \\
\hline 4 & $\begin{array}{l}\text { Methyl } \\
\text { Orange } \\
\text { (MO) }\end{array}$ & $\begin{array}{l}\mathrm{Fe}^{3+} \\
120.0 \mathrm{mg} / \mathrm{L}\end{array}$ & 3.0 & $\begin{array}{l}\mathrm{H}_{2} \mathrm{O}_{2} \text { is } \\
\text { produced } \\
\text { electroche } \\
\text { mically } \\
\text { via } \\
\text { oxygen } \\
\text { reduction } \\
\text { onthe } \\
\text { cathode. }\end{array}$ & 90 & $\begin{array}{l}\text { Cathode and anode } \\
\text { are both graphite; } \\
\text { Current=2.1 A; } \\
{[\mathrm{MO}]=106 \mathrm{mg} / \mathrm{L} ;} \\
{\left[\mathrm{Cl}^{-}\right]=16.36 \mathrm{mM} ;} \\
{\left[\mathrm{Na}_{2} \mathrm{SO}_{4}\right]=0.05 \mathrm{M} ;} \\
\mathrm{WW} \mathrm{Vol}=500 \mathrm{~mL} ; \\
\mathrm{O}_{2} \text { flow rate }=1 \\
\mathrm{~L} / \mathrm{min} .\end{array}$ & $\begin{array}{l}100 \% \\
\text { (decolora- } \\
\text { zation) } \\
96.93 \% \\
\text { (COD) }\end{array}$ & $\begin{array}{l}\text { Response surface methodology } \\
\text { was selected to optimize the } \\
\text { operating conditions. } \mathrm{NaCl} \\
\text { was used to supply the active } \\
\text { chlorine. }\end{array}$ & [132] \\
\hline 5 & Metomyl & $\begin{array}{l}\mathrm{Fe}^{3+} \\
5.6 \mathrm{mg} / \mathrm{L}\end{array}$ & 3.0 & $\begin{array}{l}\mathrm{H}_{2} \mathrm{O}_{2} \text { was } \\
\text { produced } \\
\text { from } \\
\text { reduction } \\
\text { of } \mathrm{O}_{2} \\
\text { dissolved } \\
\text { in the }\end{array}$ & 200 & $\begin{array}{l}\text { Cathode is carbon } \\
\text { belt; } \\
\text { Anode is Pt grid; } \\
\text { Current }=200 \mathrm{~mA} \text {; } \\
{[\text { Metomyl] }=200 \mathrm{~g} / \mathrm{L}} \\
\text { Lannate Vol.=150 } \\
\mathrm{mL} ;\end{array}$ & $\begin{array}{l}100 \% \\
\text { (Metomyl) } \\
98.2 \% \\
\text { (COD) }\end{array}$ & $\begin{array}{l}\text { Fe(III) was the most efficient } \\
\text { catalyst compared with cobalt, } \\
\text { silver, and copper. metomyl } \\
\text { degradation obeyed apparent } \\
\text { first-order reaction kinetics. }\end{array}$ & [124] \\
\hline
\end{tabular}


solution

6

Rhodami- $\quad \mathrm{Fe}^{0}$

ne $B \quad 15.0 \mathrm{mg} / \mathrm{L}$

(RhB)

$$
\begin{aligned}
& \mathrm{Fe}^{3+} \\
& 5.0 \mathrm{mg} / \mathrm{L}
\end{aligned}
$$

Glyphosa- $\mathrm{Mn}^{2+}$

te;

Aminome- $5.5 \mathrm{mg} / \mathrm{L}$

thyl

phosphon-

ic Acid

(AMPA)
$\mathrm{H}_{2} \mathrm{O}_{2}$ was generated in situ by adding cathodic potentiala nd bubbling air.

$\mathrm{H}_{2} \mathrm{O}_{2}$ was generated in situ in the treatment process. adding cathodic

$\left[\mathrm{Na}_{2} \mathrm{SO}_{4}\right]=0.05 \mathrm{M}$

Room temperature.

Air was bubbled for

10 min through the solution at about 1

$\mathrm{L} / \mathrm{min}$.

180

Cathode and anode are bothgraphite;

Voltage $=8 \mathrm{~V}$;

$[\mathrm{RhB}]=10 \mathrm{mg} / \mathrm{L}$;

Room temperature.

\section{$60 / 360$}

Cathode is carbon

belt;

Anode is $\mathrm{Pt}$;

Current=100 mA;

[Glyphosate] $=0.1$

$\mathrm{mM}$;

$\mathrm{WW}$ Vol. $=200 \mathrm{~mL}$;

$\left[\mathrm{Na}_{2} \mathrm{SO}_{4}\right]=0.05 \mathrm{mM}$;

$\mathrm{T}=23 \pm 2{ }^{\circ} \mathrm{C}$

$80 / 120$

Cathode is graphite;

Anode is platinum

flake;

Cathodic potential $=$ $-0.5 \mathrm{~V}$;
$>90 \%$

$(\mathrm{RhB})$

The rate of $\mathrm{RhB}$ removal at optimum catalysts

concentrations follows the order of $\mathrm{Fe}^{0}>\mathrm{Mn}^{2+}>\mathrm{Fe}^{3+}>\mathrm{Fe}^{2+}>$ $\mathrm{Cu}^{2+}$; Ferric ions was the best catalyst for the $\mathrm{RhB}$ removal with a less concentration of $5 \mathrm{mg} / \mathrm{L}$.
95\% The high mineralization degree

(Glyphosa- for glyphosate solutions

te, $60 \mathrm{~min}$ ) revealed the great performance of the EF-like process with

$100 \% \quad \mathrm{Mn}^{2+}$, which promotes the C-N

(AMPA, cleavage by $\mathrm{HO} \cdot$ attack as the

$360 \mathrm{~min}$ ) first step and the C-P cleavage in a further step.

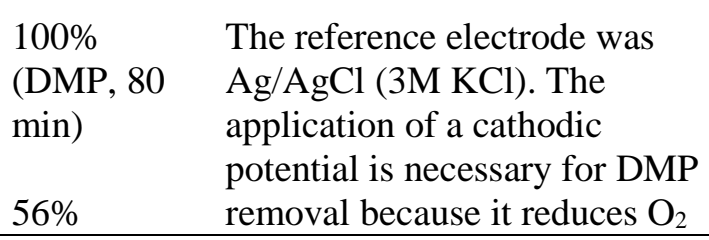




$\begin{array}{ll}\left(\mathrm{PW}_{11} \mathrm{O}_{39} \mathrm{Fe}(\mathrm{I}\right. & \text { potential- } \\ \left.\mathrm{II})\left(\mathrm{H}_{2} \mathrm{O}\right)^{4-}\right) & \text { nd } \\ & \text { bubbling } \\ 1.0 \mathrm{mM} & \text { oxygen. }\end{array}$

$[\mathrm{DMP}]=0.1 \mathrm{mM}$
$[\mathrm{DMP}]=20 \mathrm{ml} \mathrm{in}$
cathodic

compartment.

$\mathrm{O}_{2}$ flow rate $=60$

$\mathrm{mL} / \mathrm{min}$.
(TOC, 120 in solution to $\mathrm{H}_{2} \mathrm{O}_{2}$ in situ at

min) the graphite electrode and

poses reduction of $\mathrm{Fe}(\mathrm{III})$ to

$\mathrm{Fe}(\mathrm{II})$, which further catalyses

$\mathrm{H}_{2} \mathrm{O}_{2}$ reduction to $\mathrm{HO}$.

a: No. 1-3 are the heterogeneous Fenton-like process and No. 4-8 are the homogeneous Fenton-like process.

b: Dos. represents dosage.

c: Vol. represents volume; T represents temperature. 
Table 4 Study conclusion of Fenton-like process combined with cavitation

\begin{tabular}{|c|c|c|c|c|c|c|c|c|c|}
\hline \multirow[t]{2}{*}{${ }^{\mathrm{N} N O}$. } & \multirow[t]{2}{*}{ Pollutant } & \multirow{2}{*}{$\begin{array}{l}\text { Catalyst } \\
\text { bos. }\end{array}$} & \multicolumn{4}{|c|}{ Experiment conditions } & \multirow{2}{*}{$\begin{array}{l}\text { Treatment } \\
\text { efficiency }\end{array}$} & \multirow[t]{2}{*}{ Additional information } & \multirow[t]{2}{*}{ Ref. } \\
\hline & & & $\mathrm{pH}$ & $\begin{array}{l}\mathrm{H}_{2} \mathrm{O}_{2} \text { Dos. } \\
(\mathrm{mM})\end{array}$ & $\begin{array}{l}\text { Reaction } \\
\text { time (min) }\end{array}$ & ${ }^{\mathrm{c}}$ Others & & & \\
\hline${ }^{\mathrm{d}} 1$ & BPA & $\begin{array}{l}\text { Tourmaline } \\
5.0 \mathrm{~g} / \mathrm{L}\end{array}$ & 2.0 & 50.0 & 120 & $\begin{array}{l}\text { US power }=500 \mathrm{~W} \text {; } \\
\text { US frequency= } 40 \mathrm{kHz} \text {; } \\
{[\mathrm{BPA}]=5 \mathrm{mg} / \mathrm{L} ;} \\
\text { WW Vol. }=150 \mathrm{~mL} .\end{array}$ & $\begin{array}{l}98.4 \% \\
\text { (BPA) }\end{array}$ & $\begin{array}{l}\text { The experiment result was } \\
\text { due to the synergism of } \\
\text { homogeneous oxidation, a } \\
\text { heterogeneous Fenton-like } \\
\text { process and cavitation effects } \\
\text { of ultrasonic irradiation. }\end{array}$ & [56] \\
\hline 2 & $\begin{array}{l}\text { C.I. Acid } \\
\text { Orange } 7 \\
\text { (CIAO7) }\end{array}$ & $\begin{array}{l}\text { Goethite } \\
0.4 \mathrm{~g} / \mathrm{L}\end{array}$ & 5.0 & 7.8 & 30 & $\begin{array}{l}\text { US power }=80 \mathrm{~W} / \mathrm{L} ; \\
\text { US frequency }=20 \mathrm{kHz} \text {; } \\
\text { T=20 }{ }^{\circ} \text {; } \\
\text { [CIAO7] }=79.5 \mathrm{mg} / \mathrm{L} \text {; } \\
\text { WW Vol.=250 mL. }\end{array}$ & $\begin{array}{l}90 \% \\
\text { (decolori- } \\
\text { zation) }\end{array}$ & $\begin{array}{l}\text { The decolorization reaction } \\
\text { mainly takes place on the } \\
\text { surface of goethite; More } \\
\text { aggressive conditions are } \\
\text { required to achieve higher } \\
\text { TOC removal than those } \\
\text { employed to simply break the } \\
\text { chromophore group. }\end{array}$ & {$[143]$} \\
\hline e3 & $\begin{array}{l}\text { Direct } \\
\text { Orange } 39 \\
(\mathrm{DO} 39)\end{array}$ & $\begin{array}{l}\text { Goethite } \\
10.0 \mathrm{~g} / \mathrm{L} \\
\text { Fe account } \\
\text { for } 32.7 \% \\
(\mathrm{wt} \%)\end{array}$ & 3.0 & 294 & 90 & $\begin{array}{l}\text { US max power }=120 \mathrm{~W} \text {; } \\
\text { US frequency }=35 \mathrm{kHz} \\
\text { Temperature }=25{ }^{\circ} \mathrm{C} \text {; } \\
{[\text { DO39] }=0.01 \mathrm{~g} / \mathrm{L} \text {; }} \\
\text { WW Vol. }=500 \mathrm{~mL}\end{array}$ & $\begin{array}{l}97 \% \\
\text { (DO39) }\end{array}$ & $\begin{array}{l}\text { The kinetics of decolorization } \\
\text { accord with first-order } \\
\text { reaction and the rate constant } \\
\text { was } 0.0189 \mathrm{~min}^{-1} \text {. The } \\
\text { variations of catalyst and } \\
\mathrm{H}_{2} \mathrm{O}_{2} \text { dosage did not affect } \\
\text { the iron dissolution. After } \\
\text { four cycles of use, catalyst } \\
\text { capacity did not decrease } \\
\text { obviously. }\end{array}$ & [144] \\
\hline 4 & 4-chloroph- & zero valent & 7.2 & $\mathrm{H}_{2} \mathrm{O}_{2}$ was & 60 & US power= $385 \mathrm{~W}$; & $100 \%$ & 4CP and EDTA were found & [145] \\
\hline
\end{tabular}




\begin{tabular}{|c|c|c|c|c|c|c|c|c|c|}
\hline & $\begin{array}{l}\text { enol } \\
(4 \mathrm{CP}) \\
\text { EDTA }\end{array}$ & $\begin{array}{l}\text { iron }(\mathrm{ZVI}) \\
25.0 \mathrm{~g} / \mathrm{L}\end{array}$ & & $\begin{array}{l}\text { generated } \\
\text { by ZVI/ } \\
\text { EDTA } \\
\text { ligand. }\end{array}$ & & $\begin{array}{l}\text { US frequency }=20 \mathrm{kHz} \\
\mathrm{T}=20^{\circ} \mathrm{C} ; \\
{[4 \mathrm{CP}]=100 \mathrm{mg} / \mathrm{L} ;} \\
\text { EDTA Con. }=0.32 \mathrm{mM} ; \\
\text { WW Vol.=400 mL. } \\
\text { Air/Argon flow rate }=1.0 \\
\text { L/min. }\end{array}$ & $\begin{array}{l}(4 \mathrm{CP}) \\
83 \% \\
\text { (EDTA) } \\
76 \% \\
\text { (TOC) }\end{array}$ & $\begin{array}{l}\text { to follow pseudo first-order } \\
\text { degradation kinetic in the } \\
\text { US/Fenton like system at } \\
\text { neutral pH; Ultrasound } \\
\text { presented significant positive } \\
\text { effect on the degradation of } \\
\text { 4CP and EDTA. }\end{array}$ & \\
\hline 5 & $\begin{array}{l}\text { Reactive } \\
\text { Black } 5 \\
\text { (RB5) } \\
\text { EDTA }\end{array}$ & $\begin{array}{l}\text { ZVI } \\
25.0 \mathrm{~g} / \mathrm{L}\end{array}$ & 6.8 & $\begin{array}{l}\text { self-produ } \\
\text { ced in } \\
\text { reaction } \\
\text { system }\end{array}$ & 180 & $\begin{array}{l}\text { US frequency }=20 \mathrm{kHz} \\
{[\text { RB 5] }=200 \mathrm{mg} / \mathrm{L} ;} \\
\text { [EDTA] }=0.4 \mathrm{mM} ; \\
\text { WW Vol. }=500 \mathrm{~mL} ; \\
\text { Purified was supplied at } \\
\text { the flow rate of } 1.0 \\
\mathrm{~L} / \mathrm{min} .\end{array}$ & $\begin{array}{l}100 \% \\
\text { (RB5) } \\
\\
96.5 \% \\
\text { (EDTA) } \\
68.6 \% \\
\text { (TOC) } \\
92.2 \% \\
\text { (COD) }\end{array}$ & $\begin{array}{l}\text { UV was used to improve the } \\
\text { Fenton-like system, but no } \\
\text { improvement was observed. }\end{array}$ & [146] \\
\hline 6 & $\begin{array}{l}\text { 1-alkyl-3-m } \\
\text { ethylimidaz } \\
\text { olium } \\
\text { bromides } \\
([\mathrm{Cnmim}] \mathrm{Br} \\
\mathrm{n}=2,4,6 \\
8,10)\end{array}$ & $\begin{array}{l}\text { Nano ZVI } \\
0.25 \mathrm{~g} / \mathrm{L}\end{array}$ & 3.0 & 60.0 & 120 & $\begin{array}{l}\text { US power }=300 \mathrm{~W} ; \\
\text { US frequency }=45 \mathrm{kHz} \text {; } \\
\mathrm{T}=30^{\circ} \mathrm{C} ; \\
{[[\mathrm{Cnmim}] \mathrm{Br}]=2.0 \mathrm{mM} \text {; }} \\
\text { WW Vol. }=25 \mathrm{~mL} .\end{array}$ & $\begin{array}{l}92 \% \\
([\mathrm{C} 4 \mathrm{mim}] \mathrm{Br})\end{array}$ & $\begin{array}{l}\text { The degradation of } \\
\text { [Cnmim] Br accords with the } \\
\text { second order kinetics. This is } \\
\text { the first report to illustrate the } \\
\text { degradation pathway and } \\
\text { kinetics of [C4mim]Br in } \\
\text { US-nZVI/ } / \mathrm{H}_{2} \mathrm{O}_{2} \text { system. }\end{array}$ & [147] \\
\hline 7 & Phenol & $\begin{array}{l}\text { ZVI } \\
0.6 \mathrm{~g} / \mathrm{L}\end{array}$ & 3.0 & 70.6 & 60 & $\begin{array}{l}\text { US power }=180 \mathrm{~W} ; \\
\text { US frequency }=300 \mathrm{kHz} \\
\mathrm{T}=20 \pm 5^{\circ} \mathrm{C} ; \\
{[\text { Phenol }]=2.5 \mathrm{mM} ;}\end{array}$ & $\begin{array}{l}100 \% \\
\text { (Phenol) } \\
37 \% \\
\end{array}$ & $\begin{array}{l}\mathrm{H}_{2} \mathrm{O}_{2} \text { can be generated in the } \\
\text { US-Fenton-like process, and } \\
\text { the generation rate in acidic } \\
\text { and higher US frequency is }\end{array}$ & [44] \\
\hline
\end{tabular}




\begin{tabular}{|c|c|c|c|c|c|c|c|c|c|}
\hline & & $\begin{array}{l}\text { Zero valent } \\
\text { copper } \\
(\mathrm{ZVC}) \\
5.0 \mathrm{~g} / \mathrm{L}\end{array}$ & & & & $\begin{array}{l}\text { WW Vol. }=100 \mathrm{~mL} . \\
\text { Air flow rate }=1.5 \mathrm{~L} / \mathrm{min} .\end{array}$ & (TOC) & $\begin{array}{l}\text { higher than that in other } \\
\text { circumstance. ZVC catalytic } \\
\text { capacity is obvious weaker } \\
\text { than that of ZVI via the } \\
\text { comparison study in } 20 \mathrm{kHz} \\
\text { of US. }\end{array}$ & \\
\hline 8 & $\begin{array}{l}\text { bisphenol A } \\
\text { (BPA) }\end{array}$ & $\begin{array}{l}\text { Nano-ferr- } \\
\text { oferric } \\
\left(\mathrm{Fe}_{3} \mathrm{O}_{4}\right) \\
0.6 \mathrm{~g} / \mathrm{L}\end{array}$ & 7.0 & 160.0 & 480 & $\begin{array}{l}\text { US power }=100 \mathrm{~W} ; \\
\text { US frequency }=40 \mathrm{kHz} \\
\mathrm{T}=35 \pm 1^{\circ} \mathrm{C} ; \\
{[\text { BPA] }=20 \mathrm{mg} / \mathrm{L} ;} \\
\text { WW Vol. }=200 \mathrm{~mL} .\end{array}$ & $\begin{array}{l}96 \% \\
\text { (BPA) } \\
45 \% \\
\text { (TOC) }\end{array}$ & $\begin{array}{l}\text { Steel pickling waste liquor } \\
\text { was employed to obtain } \\
\mathrm{Fe}_{3} \mathrm{O}_{4} \text { nanoparticles to utilize } \\
\text { resources comprehensively } \\
\text { and reduce the cost of } \\
\text { preparation; Catalyst showed } \\
\text { good stability and activity } \\
\text { even after five recycles. }\end{array}$ & [142] \\
\hline 9 & $\begin{array}{l}\text { Nitrobenzen } \\
\mathrm{e} \\
(\mathrm{NB})\end{array}$ & $\begin{array}{l}\mathrm{Nano} \\
\alpha-\mathrm{Fe}_{2} \mathrm{O}_{3} \\
1 \mathrm{~g} / \mathrm{L}\end{array}$ & 7.0 & 10.0 & $\begin{array}{l}15(\mathrm{Nano} \\
\left.\alpha-\mathrm{Fe}_{2} \mathrm{O}_{3}\right) \\
25(\mathrm{CuO})\end{array}$ & $\begin{array}{l}\text { US power }=100 \mathrm{~W} \text {; } \\
\text { US frequency }=20 \mathrm{kHz} \\
\mathrm{T}=25 \pm 2{ }^{\circ} \mathrm{C} \\
{[\mathrm{NB}]=10 \mathrm{mg} / \mathrm{L} \text {. }}\end{array}$ & $100 \%(\mathrm{NB})$ & $\begin{array}{l}\alpha-\mathrm{Fe}_{2} \mathrm{O}_{3} \text { is a poor catalyst in } \\
\text { usual heterogeneous } \\
\text { Fenton but shows a different } \\
\text { activity when combined with } \\
\text { ultrasonic. }\end{array}$ & [45] \\
\hline 10 & $\begin{array}{l}\text { Acid orange } \\
3(\mathrm{AO} 3)\end{array}$ & $\begin{array}{l}\text { Coal fly } \\
\text { ash } \\
2.5 \mathrm{~g} / \mathrm{L}\end{array}$ & 3.0 & 5.4 & 160 & $\begin{array}{l}\text { US power }=250 \mathrm{~W} ; \\
\text { US frequency }=25 \mathrm{kHz} \\
\text { Room temperature; } \\
{[\text { AO3] }=100 \mathrm{mg} / \mathrm{L} ;} \\
\text { WW Vol. }=50 \mathrm{~mL} \text {. }\end{array}$ & $\begin{array}{l}96 \% \\
(\mathrm{AO} 3)\end{array}$ & $\begin{array}{l}\text { The reaction accord to the } \\
\text { Behnajady's kinetic model; } \\
\text { Although some linkage of } \\
\text { AO3 was broken, complete } \\
\text { mineralization dose not been } \\
\text { achieved. }\end{array}$ & [148] \\
\hline 11 & Phenol & $\begin{array}{l}\text { Coal fly } \\
\text { ash }\end{array}$ & 6.0 & 1.5 & 300 & $\begin{array}{l}\text { US power }=500 \mathrm{~W} ; \\
\text { US frequency }=40 \mathrm{kHz} \text {; } \\
\mathrm{T}=25^{\circ} \mathrm{C} ;\end{array}$ & $\begin{array}{l}88 \% \\
\text { (Phenol) }\end{array}$ & $\begin{array}{l}\text { Coal ash can provide active } \\
\text { sites for phenol degradation; } \\
\text { Too high concentration of }\end{array}$ & [149] \\
\hline
\end{tabular}




\section{$1.0 \mathrm{~g} / \mathrm{L}$}

Fe account

for $7.35 \%$

(wt\%)

$\begin{array}{ll}\text { C.I. Direct } & \text { Coal fly } \\ \text { Black 168 } & \text { ash } \\ \text { (CIDB 168) } & \end{array}$

$2.0 \mathrm{~g} / \mathrm{L}$

$\mathrm{Fe}_{2} \mathrm{O}_{3}$

account for

$5.38 \%$

(wt $\%)$

$\begin{array}{llll}\begin{array}{l}p \text {-chlorobe- } \\ \text { nzoic }\end{array} & \text { FeOOH } & 3.0 & 20.0 \\ (p-\mathrm{CBA}) & 2000.0 & & \\ & \mathrm{mg} / \mathrm{L} & & \end{array}$

$\begin{array}{lll}\mathrm{Co}^{2+} \text { or } & 3.0 \quad 2.94 \\ \mathrm{Ag}^{+} & & \\ 10.0 \mathrm{mg} / \mathrm{L} & \end{array}$

$$
\text { [Phenol] }=10 \mathrm{mg} / \mathrm{L} \text {; }
$$

$$
\text { WW Vol.=100 mL. }
$$

US power $=250 \mathrm{~W}$;

US frequency $=40 \mathrm{kHz}$; $\mathrm{T}=40 \pm 2{ }^{\circ} \mathrm{C}$

[CIDB 168] $=100 \mathrm{mg} / \mathrm{L}$; WW Vol. $=50 \mathrm{~mL}$.

US frequency $=20 \mathrm{kHz}$; Power density $=76 \mathrm{~W} / \mathrm{L}$; $[p-\mathrm{CBA}]=3.19 \times 10^{-3} \mathrm{M}$; WW Vol. $=150 \mathrm{~mL}$;

$\mathrm{T}=20{ }^{\circ} \mathrm{C}$.

$10.0 \mathrm{mg} / \mathrm{L}$

US frequency $=20 \mathrm{kHz}$; US power $=100 \mathrm{~W}$; [diazinon] $=50 \mathrm{mg} / \mathrm{L}$; WW Vol.=1000 mL;
$\mathrm{H}_{2} \mathrm{O}_{2}$ in $\mathrm{H}_{2} \mathrm{O}_{2} /$ coal ash/

ultrasonic system would reduce the degradation rate.

$99 \%$

(CIDB 168)

Three kinds of solid catalysts,

[135] namely fly ash, kaolinite or diatomaceous were examined. The degradation of dye was $99.0 \%, 92.2 \%$ and $88.3 \%$, respectively within 90 min.

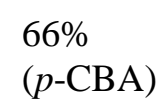

The higher apparent rates of $\mathrm{US} / \mathrm{FeOOH}-\mathrm{H}_{2} \mathrm{O}_{2}$ system versus $\mathrm{FeOOH}-\mathrm{H}_{2} \mathrm{O}_{2}$ alone was due to the continuous cleaning and chemical activation of the $\mathrm{FeOOH}$ surface by the chemical and physical effects of ultrasound. $\mathrm{T}=25{ }^{\circ} \mathrm{C}$.

$40.1 \%$
$($ diazinon,
for $\left.\mathrm{Ag}^{+}\right)$
$9 \%(\mathrm{TOC}$,
for $\left.\mathrm{Ag}^{+}\right)$

The toxicity of the diazinon was obviously reduced by a sono-Fenton process. The most important mechanism of degradation was the substitution of sulfur by oxygen on the $\mathrm{P}=\mathrm{S}$ bond in 
a: No. 1-12 are the heterogeneous Fenton-like process and No.13-14 are the homogeneous Fenton-like process.

b: Dos. represents dosage

c: Vol. represents volume; T represents temperature.

$\mathrm{d}$ : Both of the adsorption and the homogeneous contribution are responsible as well for the treatment of WW.

e: The adsorption plays an important role in the treatment of WW. 
Table 5 Study conclusion of Fenton-like process combined with MW-chemistry

\begin{tabular}{|c|c|c|c|c|c|c|c|c|c|}
\hline \multirow[t]{2}{*}{${ }^{\mathrm{a}} \mathrm{NO}$. } & \multirow[t]{2}{*}{ Pollutant } & \multirow{2}{*}{$\begin{array}{l}\text { Catalyst } \\
\text { bos. }\end{array}$} & \multicolumn{4}{|c|}{ Experiment conditions } & \multirow{2}{*}{$\begin{array}{l}\text { Treatment } \\
\text { efficiency }\end{array}$} & \multirow[t]{2}{*}{ Additional information } & \multirow[t]{2}{*}{ Ref. } \\
\hline & & & $\mathrm{pH}$ & $\begin{array}{l}\mathrm{H}_{2} \mathrm{O}_{2} \text { Dos. } \\
(\mathrm{mM})\end{array}$ & $\begin{array}{l}\text { Reaction } \\
\text { time (min) }\end{array}$ & ${ }^{\mathrm{c}}$ Others & & & \\
\hline 1 & $\begin{array}{l}\text { Rhodamine B } \\
\text { (RhB) }\end{array}$ & $\begin{array}{l}\mathrm{Fe}_{3} \mathrm{O}_{4} \\
1.3 \mathrm{~g} / \mathrm{L}\end{array}$ & 4.0 & 50 & 5 & $\begin{array}{l}\text { MW power }=300 \mathrm{~W} ; \\
{[\mathrm{RhB}]=100 \mathrm{mg} / \mathrm{L} ;} \\
\mathrm{WW} \text { Vol.=40 mL; } \\
\mathrm{T}=80^{\circ} \mathrm{C} .\end{array}$ & $99 \%(\mathrm{RhB})$ & $\begin{array}{l}\text { Six cycle uses for RhB } \\
\text { removal revealed that the } \\
\text { magnetic catalyst was stable, } \\
\text { recoverable, highly active, and } \\
\text { easy to separate using an } \\
\text { external magnet. }\end{array}$ & [55] \\
\hline 2 & $\begin{array}{l}\text { 2-nitrophenol } \\
\text { (2-NP) }\end{array}$ & $\begin{array}{l}\mathrm{CuO} / \mathrm{Al} \\
5.0 \mathrm{~g} / \mathrm{L}\end{array}$ & 4.0 & 6 & 5 & $\begin{array}{l}\text { MW power= } 300 \mathrm{~W} ; \\
{[2-\mathrm{NP}]=200 \mathrm{mg} / \mathrm{L} ;} \\
\text { WW Vol.=10 mL; } \\
\mathrm{T}=60^{\circ} \mathrm{C} .\end{array}$ & $\begin{array}{l}97 \% \\
(2-\mathrm{NP}) \\
79 \% \\
(\mathrm{TOC})\end{array}$ & $\begin{array}{l}\text { The apparent activation energy } \\
\text { of } 2 \text {-NP conversion was } \\
\text { estimated to be } 73.1 \mathrm{~kJ} / \mathrm{mol} \text {. } \\
\text { The catalyst exhibited limited } \\
\text { stability, after } 4 \text { experimental } \\
\text { runs in acidic medium, the } \\
\text { catalyst activities decreased by } \\
\text { about } 4 \% \text {. }\end{array}$ & [47] \\
\hline 3 & $\begin{array}{l}\text { 4-nitrophenol } \\
\text { (4-NP) }\end{array}$ & $\begin{array}{l}\mathrm{CuO} / \mathrm{Al}_{2} \mathrm{O}_{3} \\
40.0 \mathrm{~g} / \mathrm{L}\end{array}$ & 6.0 & 25 & 6 & $\begin{array}{l}\text { MW power= } 100 \mathrm{~W} ; \\
{[4-\mathrm{NP}]=50 \mathrm{mg} / \mathrm{L} ;} \\
\text { WW Vol.=100 mL; } \\
\mathrm{T}=70^{\circ} \mathrm{C} .\end{array}$ & $\begin{array}{l}93 \% \\
(4-N P)\end{array}$ & $\begin{array}{l}\text { The catalyst can be reused at } \\
\text { least } 8 \text { times and still keep the } \\
\text { high catalytic capacity (more } \\
\text { than } 90 \% \text { of } 4 \text {-NP was } \\
\text { removed). The total leaching } \\
\text { amount of copper after } 5 \\
\text { cycles was less than } 1 \% \text {. }\end{array}$ & [163] \\
\hline 4 & $\begin{array}{l}\text { Pharmaceutic } \\
\text { al WW }\end{array}$ & $\begin{array}{l}\mathrm{Fe}^{3+} \\
1372.0 \mathrm{mg} / \mathrm{L}\end{array}$ & 4.4 & 38.2 & 6 & $\begin{array}{l}\text { MW power=300 W; } \\
\text { COD=49913 mg/L; } \\
\text { WW Vol.=50 mL; } \\
\text { T=28 }{ }^{\circ} \mathrm{C} .\end{array}$ & $\begin{array}{l}57.5 \% \\
\text { (COD) }\end{array}$ & $\begin{array}{l}\mathrm{BOD}_{5} / \mathrm{COD} \text { was enhanced } \\
\text { from } 0.165 \text { to } 0.470 \\
\text { MW-Fe(III)- } \mathrm{H}_{2} \mathrm{O}_{2} \text { process } \\
\text { reduced the yield of sludge }\end{array}$ & [54] \\
\hline
\end{tabular}


and improved COD removal efficiency; The qualities of sludge (such as settling and biodegradation quality) were improved.

\begin{tabular}{|c|c|c|c|c|c|c|c|c|}
\hline 5 & $\begin{array}{l}\text { Pharmaceutic } \\
\text { al WW }\end{array}$ & $\begin{array}{l}\mathrm{Fe}^{3+} \\
420.0 \mathrm{mg} / \mathrm{L}\end{array}$ & $\begin{array}{l}6.5- \\
7.1\end{array}$ & 250 & 6 & $\begin{array}{l}\text { MW power=539 W; } \\
\text { COD=1590-2200 } \\
\text { mg/L; } \\
\text { TOC=150-210 } \\
\text { mg/L; } \\
\text { WW Vol. }=1000 \mathrm{~mL} ; \\
\text { Coloration }=50 .\end{array}$ & $\begin{array}{l}62 \% \\
\text { (TOC) }\end{array}$ & $\begin{array}{l}\text { MW irradiation makes the } \\
\text { catalyst dosage and oxidant } \\
\text { dosages were both reduced, } \\
\text { and reaction time was } \\
\text { shortened too. }\end{array}$ \\
\hline & $\begin{array}{l}\text { Olive mill } \\
\text { WW (OMW) }\end{array}$ & $\begin{array}{l}\mathrm{Cu}^{2+} \\
200.0 \mathrm{mg} / \mathrm{L}\end{array}$ & 4.7 & 3941.2 & 7 & $\begin{array}{l}\text { MW power= } 680 \mathrm{~W} ; \\
\mathrm{COD}=74500 \mathrm{mg} / \mathrm{L} ; \\
{[\text { Polyphenols] = }} \\
16500 \mathrm{mg} / \mathrm{L} ; \\
\text { WW Vol.=100 mL. }\end{array}$ & $\begin{array}{l}90 \% \\
\text { (decolorizat- } \\
\text { ion) } \\
81.8 \% \\
\text { (phenolic } \\
\text { compounds) }\end{array}$ & $\begin{array}{l}\mathrm{MW} / \mathrm{H}_{2} \mathrm{O}_{2} \text { system use less } \\
\text { treatment time compared with } \\
\mathrm{UV} / \mathrm{H}_{2} \mathrm{O}_{2} \text { system; The removal } \\
\text { of pollutants was most likely } \\
\text { due to } \mathrm{MW} \text { radiation rather } \\
\text { than the substitution of iron by } \\
\mathrm{Cu}(\mathrm{II}) \text {. }\end{array}$ \\
\hline
\end{tabular}

a: No. 1-3 are the heterogeneous Fenton-like process and No. 4-5 are the homogeneous Fenton-like process.

b: Dos. represents dosage

c: Vol. represents volume; $\mathrm{T}$ represents temperature. 
Table 6 Operation costs for an 85\% COD removal rate for synthetic WWs and a 70\% COD removal rate for actual olive oil WW [210]

\begin{tabular}{lcc}
\hline \multirow{2}{*}{ Organics } & \multicolumn{2}{l}{ Operation cost $\left(€ / \mathrm{m}^{3}\right)$} \\
\cline { 2 - 3 } & Conductive-Diamond Electrochemical Oxidation & Fenton \\
\hline Butyric acid & 11 & 35 \\
2-Propanol & 9 & 71 \\
4-Chlorophenol & 13 & 2 \\
2-Naphthol & 13 & 7 \\
Eriochrome Black T & 35 & 46 \\
Olive oil & 11 & 5 \\
\hline
\end{tabular}


Table 7 Cost analysis of a zero-valent iron catalysed Fenton-like process enhanced by US cavitation [139]

\begin{tabular}{llllll}
\hline $\begin{array}{l}\text { Power intensity } \\
\left(\mathrm{W} \mathrm{L}^{-1}\right)\end{array}$ & $\begin{array}{l}\text { Decolourization } \\
\text { rate }(\%)\end{array}$ & $\begin{array}{l}\text { Irradiation } \\
\text { time }(\mathrm{min})\end{array}$ & $\begin{array}{l}\text { Power consumption } \\
\left(\mathrm{kWh} \mathrm{m}^{-3}\right)\end{array}$ & $\begin{array}{l}\text { Electricity cost } \\
\left(\mathrm{USD} \mathrm{m}^{-3}\right)\end{array}$ & $\begin{array}{l}\text { Total cost } \\
\left.(\mathrm{USD} \mathrm{m})^{-3}\right)\end{array}$ \\
\hline 80 & 80 & 30 & 40.0 & $3.20\left({ }^{\mathrm{a}} 92.8 \%\right)$ & 3.45 \\
100 & 98 & 25 & 41.7 & $3.33(93.0 \%)$ & 3.58 \\
120 & 98 & 15 & 30.0 & $2.40(90.6 \%)$ & 2.65 \\
140 & 98 & 10 & 23.3 & $1.87(88.2 \%)$ & 2.12 \\
\hline
\end{tabular}

a: The ratio of electricity to total cost. 

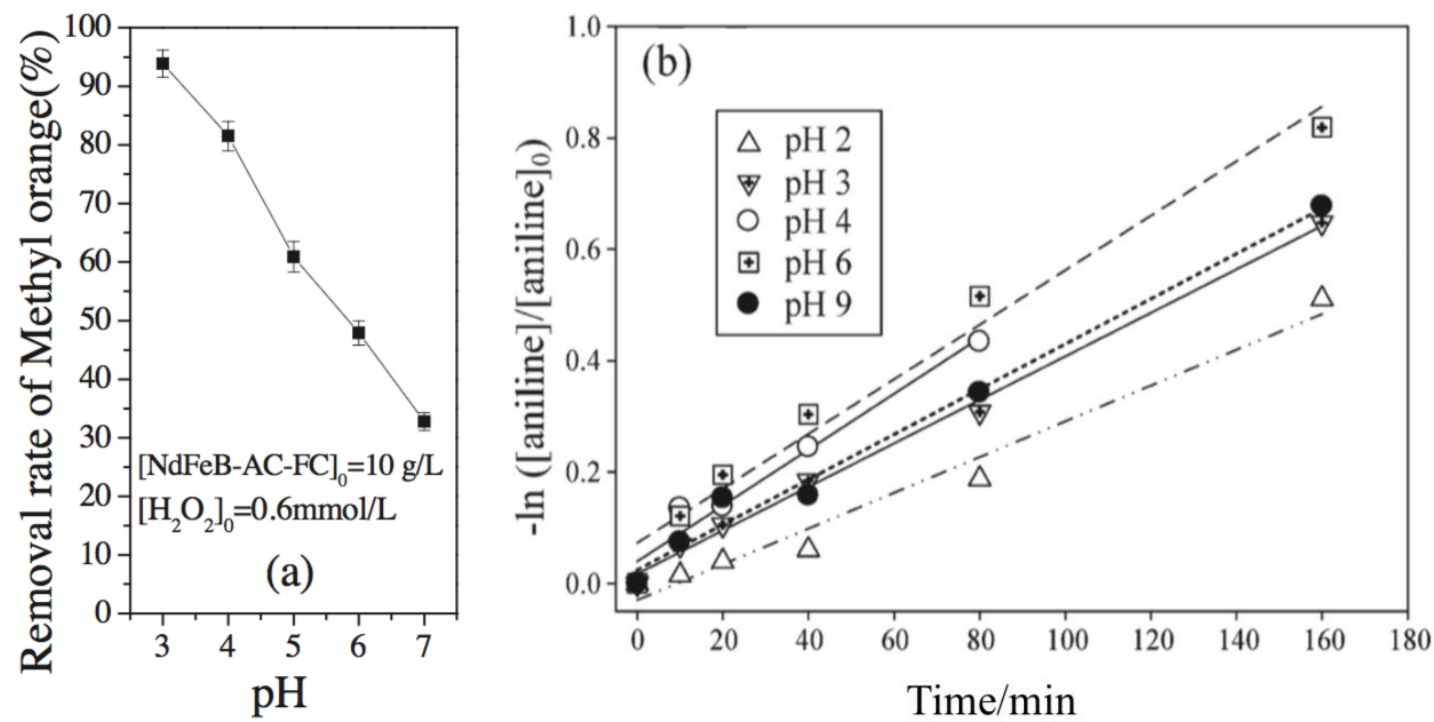

Figure 1 Effect of $\mathrm{pH}$ on the removal rate of organics in two different heterogeneous

Fenton-like processes $[51,60]$ 


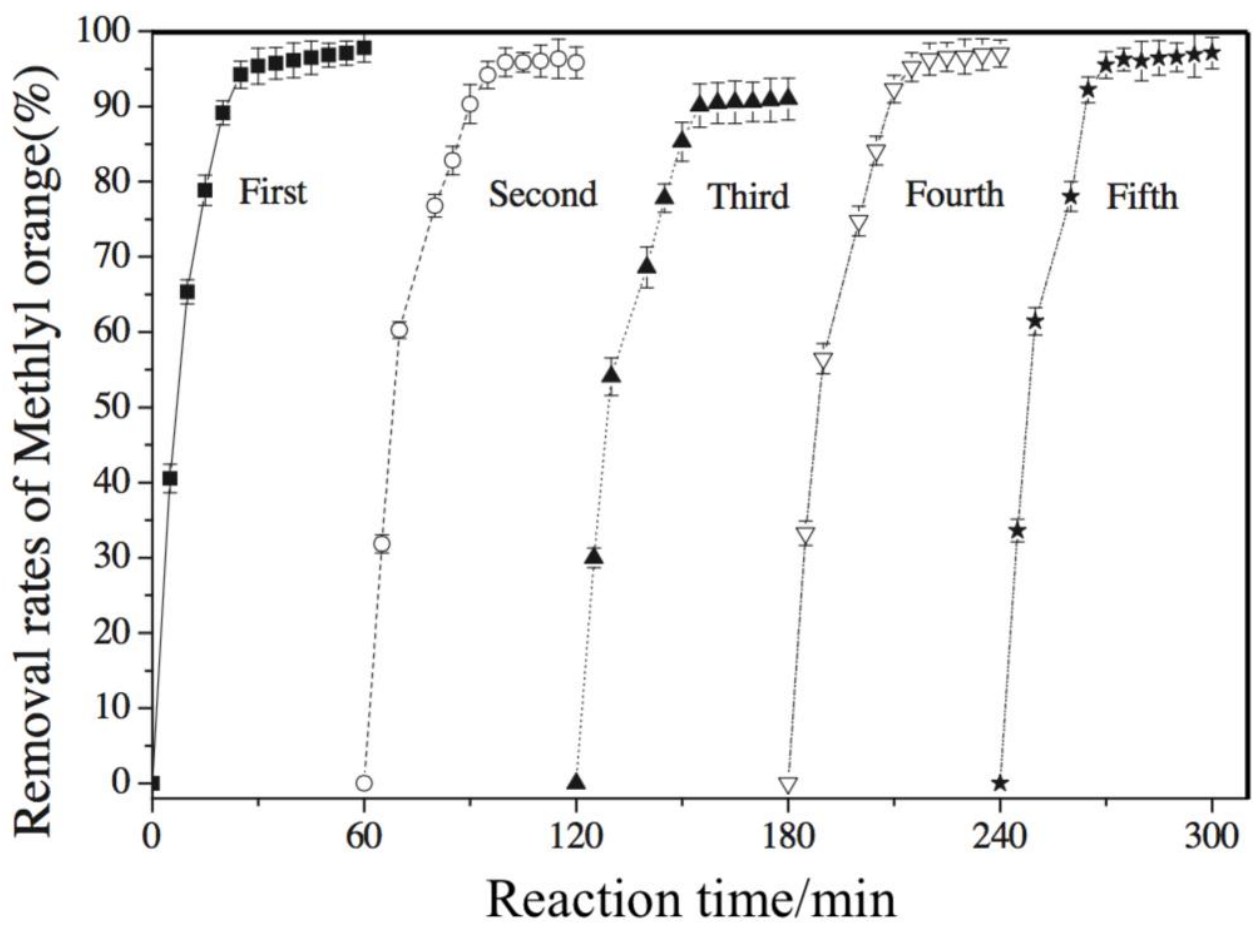

Figure 2 Typical stability study of catalyst used in heterogeneous Fenton-like process [51] 

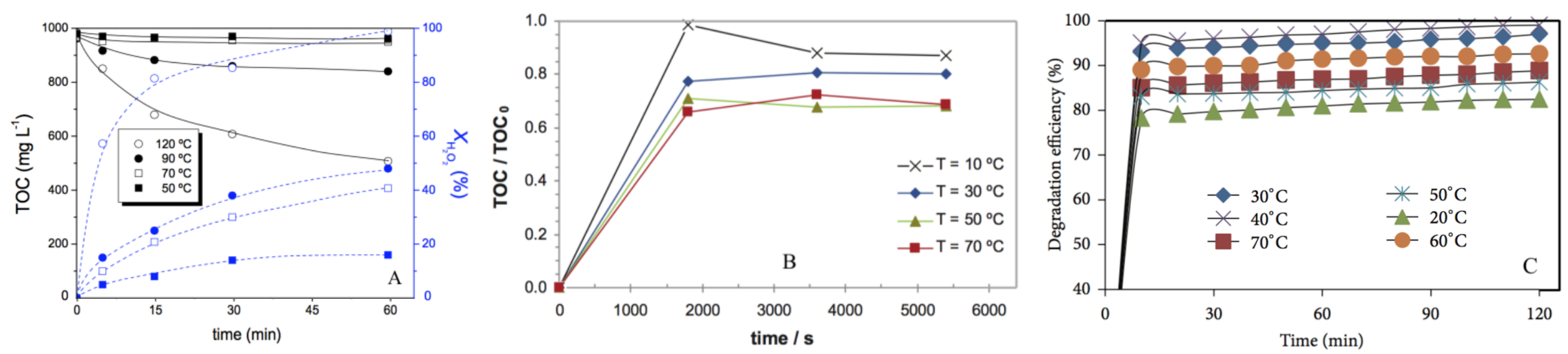

Figure 3 Effect of higher WW treatment temperature [17, 62, 81] 


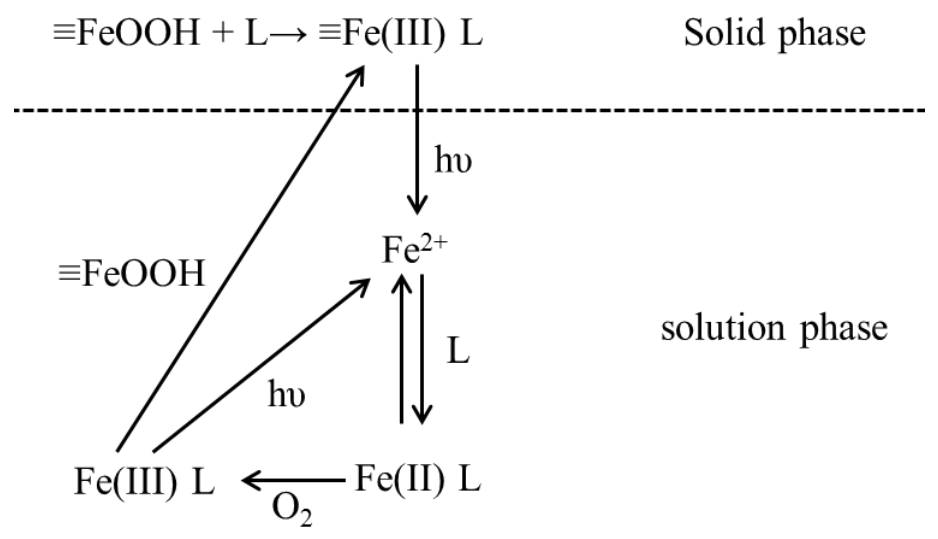

Figure 4 Model of photo-reductive dissolution of $\mathrm{FeOOH}$ in the heterogeneous system [91] 


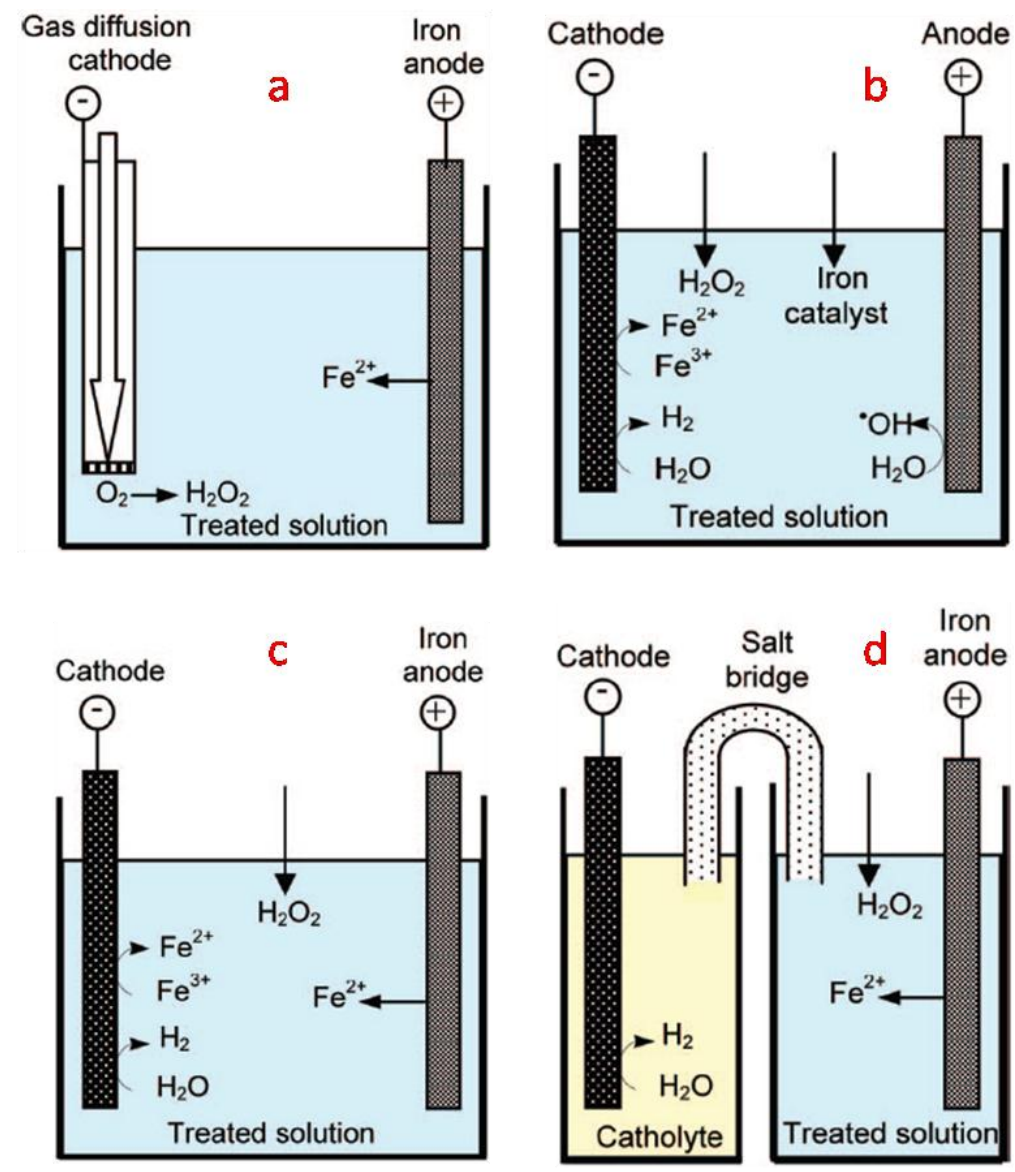

Figure 5 Typical electro-Fenton-like systems [43] 


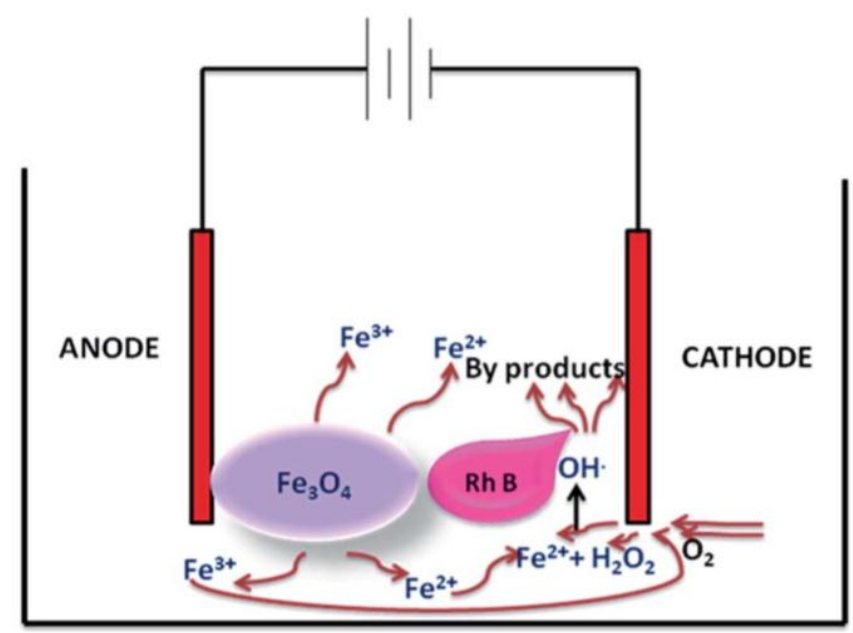

Figure 6 Degradation mechanism of dye in magnetite-catalysed Fenton-like process [131] 


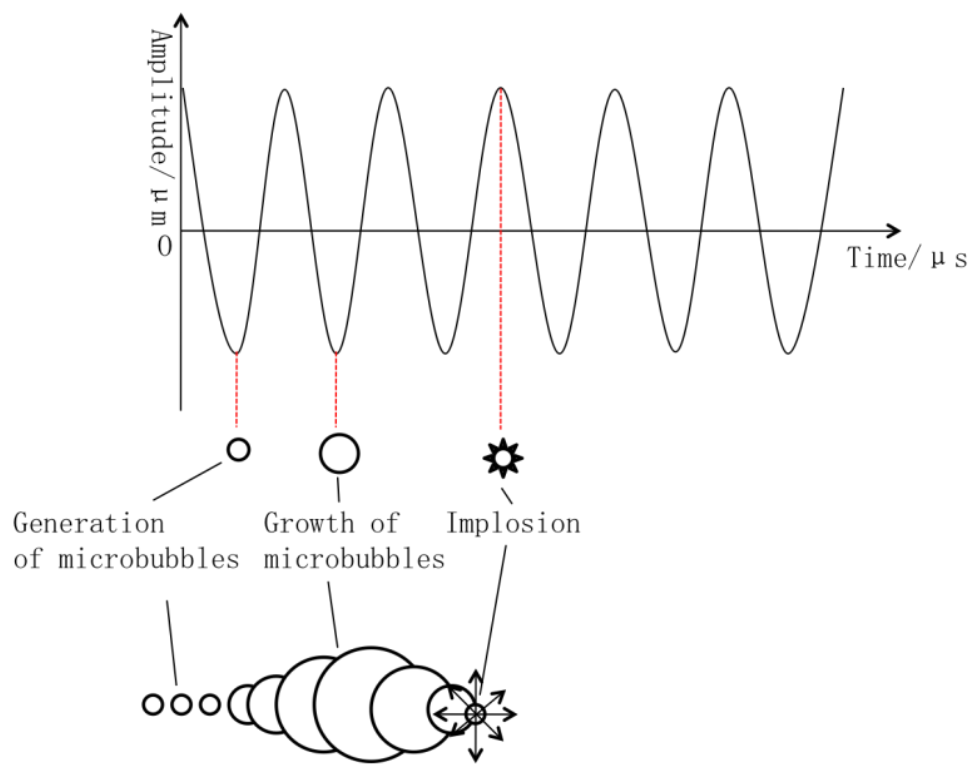

Figure 7 Typical scheme of acoustic cavitation 


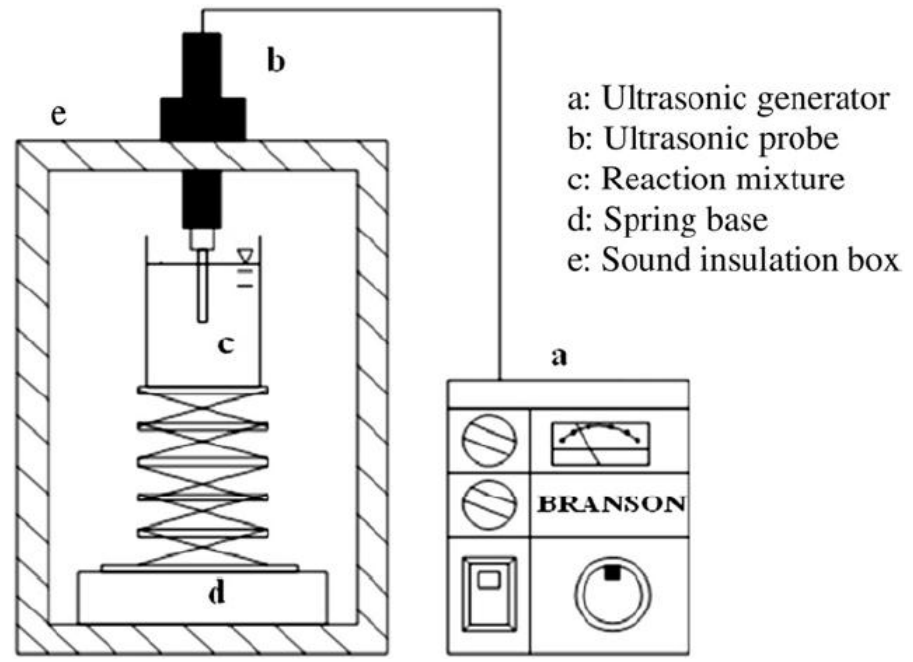

Figure 8 Typical ultrasonic-Fenton/Fenton-like system [139] 


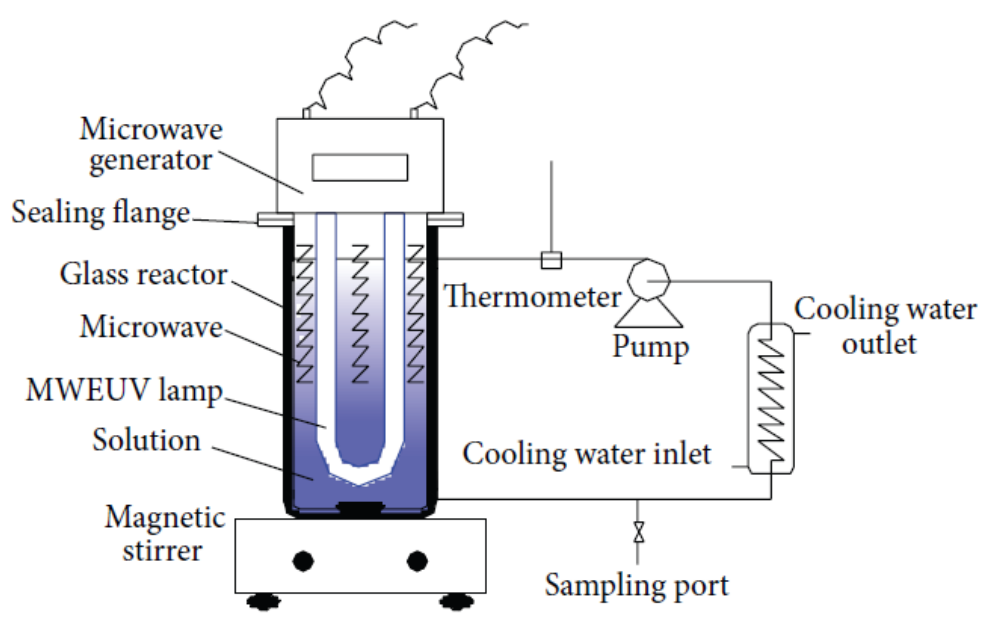

Figure 9 Typical MW-UV-Fenton-like system [160] 


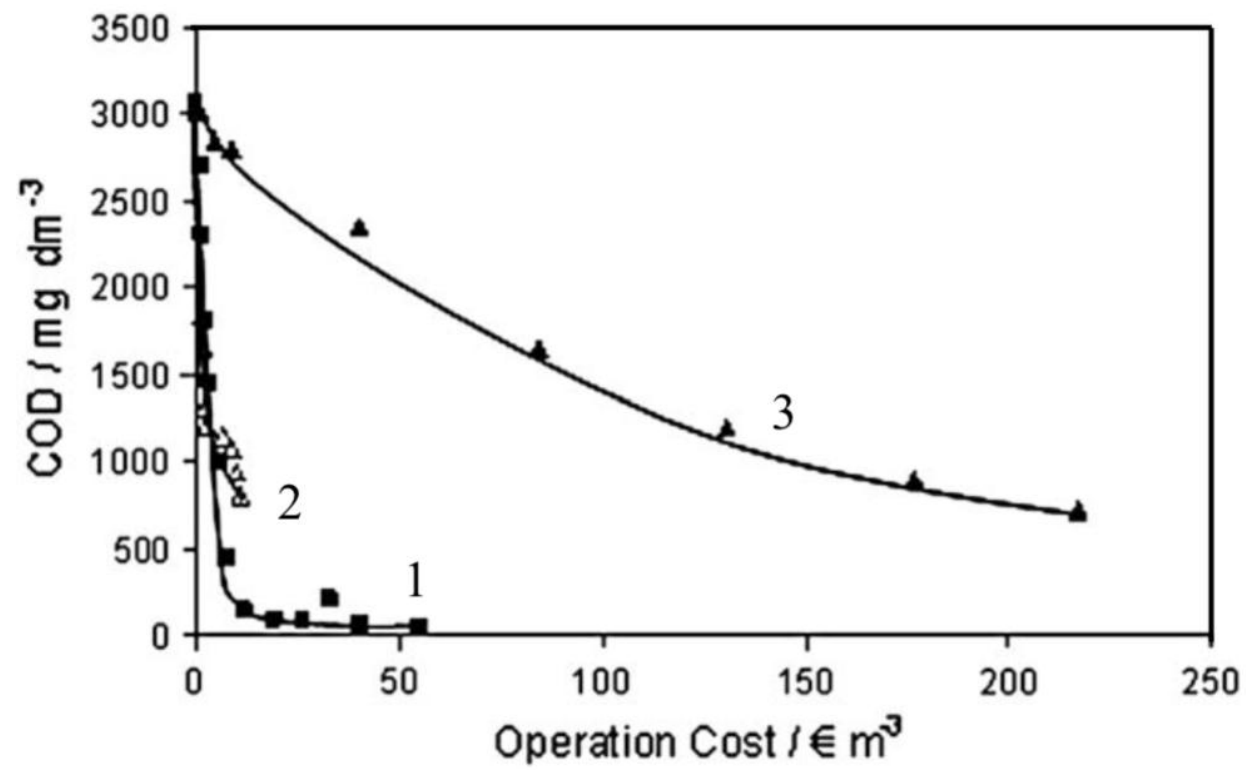

Figure 10 Variation of the treatment cost with COD removal in the treatment of olive oil mill wastewater. (1-conductive-diamond electrochemical oxidation; 2-Fenton oxidation; 3-ozonation oxidation) [210] 


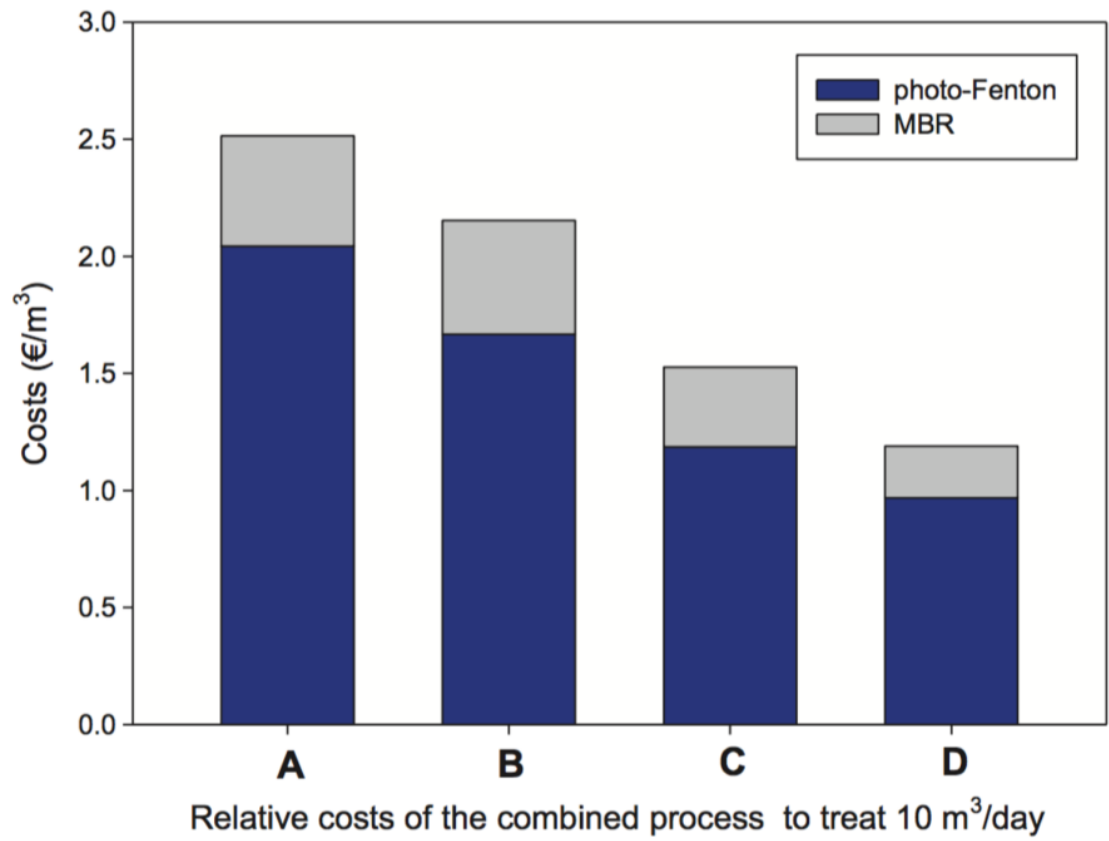

Figure 11 Cost of the combination process of photo-Fenton with MBR to treat $10 \mathrm{~m}^{3} /$ day as a function of the concentration of organics (A: Dissolved organic carbon (DOC)=500 mg L ${ }^{-1}$, mineralization=57\%; $\mathrm{B}: \mathrm{DOC}=500 \mathrm{mg} \mathrm{L} \mathrm{L}^{-1}$, mineralization=40\%; $\mathrm{C}: \mathrm{DOC}=200 \mathrm{mg} \mathrm{L}^{-1}$; mineralization=33\%; D: DOC $=50 \mathrm{mg} \mathrm{L}^{-1}$; mineralization=20\%) [211] 


\section{Table Captions}

Table 1 Conclusion of typical studies of the Fenton-like process alone

Table 2 Study conclusion of Fenton-like process combined with photochemistry

Table 3 Study conclusion of Fenton-like process combined with electrochemistry

Table 4 Study conclusion of Fenton-like process combined with cavitation

Table 5 Study conclusion of Fenton-like process combined with MW-chemistry

Table 6 Operation costs for an 85\% COD removal rate for synthetic WWs and a 70\%

COD removal rate for actual olive oil WW [210]

Table 7 Cost analysis of a zero-valent iron catalysed Fenton-like process enhanced by

US cavitation [139] 


\section{Figure captions}

Figure 1 Effect of $\mathrm{pH}$ on the removal rate of organics in two different heterogeneous Fenton-like processes [51, 60]

Figure 2 Typical stability study of catalyst used in heterogeneous Fenton-like process [51]

Figure 3 Effect of higher WW treatment temperature [17, 62, 81]

Figure 4 Model of photo-reductive dissolution of $\mathrm{FeOOH}$ in the heterogeneous system [91]

Figure 5 Typical electro-Fenton-like systems [43]

Figure 6 Degradation mechanism of dye in magnetite-catalysed Fenton-like process [131]

Figure 7 Typical scheme of acoustic cavitation

Figure 8 Typical ultrasonic-Fenton/Fenton-like system [139]

Figure 9 Typical MW-UV-Fenton-like system [160]

Figure 10 Variation of the treatment cost with COD removal in the treatment of olive oil mill wastewater. (1-conductive-diamond electrochemical oxidation; 2-Fenton oxidation; 3-ozonation oxidation) [210]

Figure 11 Cost of the combination process of photo-Fenton with MBR to treat 10 $\mathrm{m}^{3} /$ day as a function of the concentration of organics (A: Dissolved organic carbon $(\mathrm{DOC})=500 \mathrm{mg} \mathrm{L}^{-1}$, mineralization $=57 \%$; $:$ DOC $=500 \mathrm{mg} \mathrm{L}^{-1}$, mineralization $=40 \%$; $\mathrm{C}: \mathrm{DOC}=200 \mathrm{mg} \mathrm{L}{ }^{-1}$; mineralization=33\%; D: DOC $=50 \mathrm{mg} \mathrm{L}^{-1}$; mineralization=20\%) [211] 